\title{
Do Lipid-Based Nanoparticles Hold Promise for Advancing the Clinical Translation of Anticancer Alkaloids?
}

\author{
Jian Sheng Loh ${ }^{1,+} \oplus^{\oplus}$, Li Kar Stella Tan ${ }^{2,+}$, Wai Leng Lee ${ }^{3} \mathbb{C}$, Long Chiau Ming ${ }^{4}\left(\mathbb{0}\right.$, Chee Wun How ${ }^{1,5}$, \\ Jhi Biau Foo ${ }^{2,6}$, Nurolaini Kifli ${ }^{4}$, Bey Hing Goh ${ }^{1,7,8, *(1)}$ and Yong Sze Ong $1,5,7, *(\mathbb{D})$
}

1 School of Pharmacy, Monash University Malaysia, Bandar Sunway, Subang Jaya 47500, Malaysia; loh.jiansheng@monash.edu (J.S.L.); How.CheeWun@monash.edu (C.W.H.)

2 School of Pharmacy, Faculty of Health \& Medical Sciences, Taylor's University, Jalan Taylors 1, Subang Jaya 47500, Malaysia; stellalikar.tan@sd.taylors.edu.my (L.K.S.T.); jhibiau.foo@taylors.edu.my (J.B.F.)

3 School of Science, Monash University Malaysia, Subang Jaya 47500, Malaysia; lee.wai.leng@monash.edu

4 PAP Rashidah Sa'adatul Bolkiah Institute of Health Sciences, Universiti Brunei Darussalam, Gadong BE1410, Brunei; long.ming@ubd.edu.bn (L.C.M.); nurolaini.kifli@ubd.edu.bn (N.K.)

5 Health and Well-Being Cluster, Global Asia in the 21st Century (GA21) Platform, Monash University Malaysia, Subang Jaya 47500, Malaysia

6 Centre for Drug Discovery and Molecular Pharmacology (CDDMP), Faculty of Health \& Medical Sciences, Taylor's University, Jalan Taylors 1, Subang Jaya 47500, Malaysia

7 Biofunctional Molecule Exploratory Research Group (BMEX), School of Pharmacy, Monash University Malaysia, Subang Jaya 47500, Malaysia

8 College of Pharmaceutical Sciences, Zhejiang University, Hangzhou 310058, China

* Correspondence: goh.bey.hing@monash.edu (B.H.G.); Ong.YongSze@monash.edu (Y.S.O.)

+ These authors contributed equally.

Citation: Loh, J.S.; Tan, L.K.S.; Lee, W.L.; Ming, L.C.; How, C.W.; Foo, J.B.; Kifli, N.; Goh, B.H.; Ong, Y.S. Do Lipid-Based Nanoparticles Hold Promise for Advancing the Clinical Translation of Anticancer Alkaloids? Cancers 2021, 13, 5346. https:/ / doi.org/10.3390/cancers13215346

Academic Editor: Claudio Luparello

Received: 29 April 2021

Accepted: 10 June 2021

Published: 25 October 2021

Publisher's Note: MDPI stays neutral with regard to jurisdictional claims in published maps and institutional affiliations.

Copyright: (c) 2021 by the authors. Licensee MDPI, Basel, Switzerland. This article is an open access article distributed under the terms and conditions of the Creative Commons Attribution (CC BY) license (https:// creativecommons.org/licenses/by/ $4.0 /)$.
Simple Summary: Alkaloids are natural products that possess numerous pharmacological activities and have been exploited effectively to treat cancer. However, the clinically approved anticancer alkaloids are generally limited by serious side effects due to their lack of specificity to cancer cells, indiscriminate tissue distribution and toxic formulation excipients. Lipid-based nanoparticles represent the most effective drug delivery system concerning clinical translation owing to their unique appealing characteristics for drug delivery. This review aims to assess the potential of different types of lipid-based nanoparticles in encapsulating anticancer alkaloids. Our review shows that alkaloids encapsulated in lipid-based nanoparticles generally displayed an enhanced efficacy and toxicity profile than unencapsulated alkaloids in various cancers. Encapsulated alkaloids also demonstrated the ability to overcome multidrug resistance in cell lines and animal models. These findings support the broad application of lipid-based nanoparticles to encapsulate anticancer alkaloids and facilitate their clinical translation.

Abstract: Since the commercialization of morphine in 1826, numerous alkaloids have been isolated and exploited effectively for the betterment of mankind, including cancer treatment. However, the commercialization of alkaloids as anticancer agents has generally been limited by serious side effects due to their lack of specificity to cancer cells, indiscriminate tissue distribution and toxic formulation excipients. Lipid-based nanoparticles represent the most effective drug delivery system concerning clinical translation owing to their unique, appealing characteristics for drug delivery. To the extent of our knowledge, this is the first review to compile in vitro and in vivo evidence of encapsulating anticancer alkaloids in lipid-based nanoparticles. Alkaloids encapsulated in lipid-based nanoparticles have generally displayed enhanced in vitro cytotoxicity and an improved in vivo efficacy and toxicity profile than free alkaloids in various cancers. Encapsulated alkaloids also demonstrated the ability to overcome multidrug resistance in vitro and in vivo. These findings support the broad application of lipid-based nanoparticles to encapsulate anticancer alkaloids and facilitate their clinical translation. The review then discusses several limitations of the studies analyzed, particularly the discrepancies in reporting the pharmacokinetics, biodistribution and toxicity data. Finally, we conclude with examples of clinically successful encapsulated alkaloids that have received regulatory approval and are undergoing clinical evaluation. 
Keywords: alkaloid; anticancer; lipid-based nanoparticles; liposome; solid lipid nanoparticle; nanostructured lipid carriers

\section{Introduction}

Cancer ranks as the leading cause of morbidity and mortality in the world with an estimated 19.3 million new cases and 9.9 million deaths reported in 2020 [1]. Although stupendous advances have been made in understanding the molecular underpinnings and genomic landscape of cancers, the oncologic outcomes remain poor. Current treatments of cancer include surgery, radiation therapy and chemotherapy [2-4]. However, the administration of anti-cancer drugs, including chemotherapeutic drugs, biologic agents and immunotherapeutic drugs using the conventional methods, has been hindered by various pharmacological issues, including toxicities, unsatisfactory therapeutic efficacy and drug resistance $[5,6]$. These unsatisfactory oncologic outcomes have revitalized the interest in natural product-derived anticancer agents.

Bioactive natural products have been serving as the primary source of medicines by numerous cultures around the world over the past millennia [7]. With the rise of modern scientific approaches, the past century has witnessed a surge of highly active compounds derived from natural products and their derivatives with a precise mode of actions for the treatment of a myriad of diseases. Natural products have gained great interest due to their vast scaffold diversity and structural complexity unrivaled by current synthetic drugs [8]. An analysis of all FDA-approved small-molecule drugs from 1981 to 2014 revealed that approximately $51 \%$ were natural products and their derivatives, and about $80 \%$ of anti-cancer small-molecule drugs were natural products and their derivatives [9]. Several classes of natural products have been identified, including terpenoid, polyketide, phenylpropanoid and alkaloid [10].

Alkaloid is a class of naturally occurring nitrogen containing heterocyclic organic compounds with a wide range of pharmacological activities, often considered privileged structures in drug discovery $[10,11]$. Since the commercialization of the first alkaloid morphine in 1826, numerous alkaloids have been isolated and exploited effectively for the betterment of mankind. Today, alkaloid drugs have been approved by the FDA for the treatment of cancer, Alzheimer's disease, Parkinson's disease, migraine, pain control, erectile dysfunction, heart failure and many more [12,13]. Alkaloids have demonstrated wide-spectrum anticancer activity by inhibiting topoisomerase I and suppressing microtubule dynamics $[14,15]$. The most notable anticancer alkaloid drugs that continue to maintain palpable significance in clinical practice include paclitaxel, docetaxel, vincristine, vinblastine, irinotecan and topotecan. However, the administration of anticancer alkaloids has generally been limited by serious side effects due to their lack of specificity to cancer cells, indiscriminate tissue distribution and toxic formulation excipients [16-18]. These limitations prompted unceasing investigational efforts to develop effective and safe nanoformulations and improve oncologic outcomes.

Cancer is a disease where the adequacy of delivery of extremely potent yet toxic chemotherapeutic drugs can result in either efficacious responses or serious morbidity [19]. To mitigate these limitations, tailor-designed nanomedicines have emerged as promising strategy for cancer treatment owing to their improved pharmacokinetic properties, therapeutic efficacy, specific targeting of tissues and minimized adverse effects [20]. Furthermore, the use of nanotechnology allows drugs to traverse biological barriers such as the blood-brain barrier [19,21]. Among all the different classes of nanocarriers, lipid-based nanoparticles represent the most established and effective drug delivery system concerning clinical translation, with multiple formulations having already obtained U.S. Food and Drug Administration (FDA) approval for clinical use [20]. Lipid-based nanoparticles have received great attention due to their unique, appealing characteristics for drug delivery, including (1) excellent biocompatibility and biodegradability; (2) improved solubility and 
stability of difficult-to-deliver drugs, including both hydrophobic and hydrophilic drugs; (3) enhanced therapeutic index by improving efficacy and reducing toxicity; (4) versatility which allows chemical modifications and surface coatings and (5) ability of co-deliver two different anticancer drugs to enable precise spatiotemporal multi-drug treatment [22-25]. These advantages of lipid-based nanoparticles have been exploited effectively in enhancing the efficacy and reducing the toxicity of anticancer alkaloids, the most exceptional of which are Onivyde (liposomal irinotecan), Marqibo (liposomal vincristine) and Lipusu (liposomal paclitaxel), which have received regulatory approval for clinical use [26]. These uplifting translational successes have motivated an exponential increase in research investigating the potential and effectiveness of encapsulating anticancer alkaloids in different lipid-based nanoparticles. Nevertheless, despite the stupendous therapeutic potential demonstrated by nanomedicines in pre-clinical studies, there are still many shortcomings to be solved.

This review aims to provide some insights and updates on the potential of lipid-based nanoformulations of anticancer alkaloids based on in vitro and in vivo evidence. This review begins with an overview of the current trends and understanding of nanomedicines, then discusses the medicinal uses of alkaloids and their anticancer mechanism of action. Next, the review describes the limitations of currently approved anticancer alkaloid drugs which necessitates their encapsulation in nanoparticles. This is followed by a comprehensive discussion on the most promising lipid-based nanoparticles, which are liposomes, micelles, solid lipid nanoparticles (SLN), nanostructured lipid carriers (NLC) and niosomes. The review then summarizes the findings and limitations of several pre-clinical experiments, focusing on the comparisons of the in vitro and in vivo efficacy and toxicity between free alkaloids and alkaloids encapsulated in lipid-based nanoparticles. Finally, the review highlights several anticancer alkaloids encapsulated in lipid-based nanoparticles that have received regulatory approval and are undergoing clinical evaluation. To the extent of our knowledge, this is the first review to compile the in vitro and in vivo evidence of encapsulating anticancer alkaloids in lipid-based nanoparticles.

\section{Nanotechnology}

The prefix "nano" comes from ancient Greek which represents "dwarf" [27]. One nanometer $(\mathrm{nm})$ is an international System of Units that equals to one billionth of a meter. According to the National Nanotechnology Initiative (NNI), nanotechnology refers to the comprehension and manipulation of matter at atomic or molecular levels between 1 to $100 \mathrm{~nm}$, where unique phenomena facilitate the novel applications [28]. It involves various scientific disciplines (i.e., engineering, technology, medicine, chemistry, physics, biology or a combination of these disciplines) [29]. Nanotechnology has been utilized in numerous medical-related fields including magnetic resonance imaging (MRI), hyperthermic destruction of tumor, proteins detection, diagnosis, pharmacological research, cells and biological molecules purification. Nowadays, numerous nanoparticles have been studied and developed for clinical use including liposomes, nanocapsules, nanorods, nanowires, nanospheres, nanoshells, nanotubes, nanopores and dendrimers [27,30,31].

In general, nanomaterials can be divided into four different categories which are carbon-based, inorganic-based, organic-based and composite-based nanomaterials. Carbonbased nanomaterials can be found in morphologies such as sphere-shaped, ellipsoidshaped, tube-shaped or horn-shaped [32]. These nanomaterials can further be classified into graphene quantum dots (0-D), carbon nanotubes (1-D) and graphene (2-D) based on their dimensions, where 0-D refers to no dimension, 1-D refers to one dimension and 2-D refers to two dimensions at nanoscale [33,34]. Inorganic-based nanomaterials comprise metal-based and metal oxide-based nanoparticles. Metal-based nanoparticles are comprised of pure metal nanoparticles (i.e., iron, magnesium, zinc, platinum, titanium, copper, gold, silver and alginate nanoparticles). Metal-based nanoparticles can be bound to oxygen, becoming metal oxide nanomaterials (i.e., zinc oxide, silver oxide, etc.) $[35,36]$. Organic-based nanomaterials are mainly made of organic matter except inorganic and carbon-based nanomaterials. These organic-based nanomaterials can be transformed 
into liposomes, micelles, dendrimers and polymer nanoparticles that are very useful in drug delivery through noncovalent interactions [36,37]. Composite-based nanomaterials consist of several phases, with one of the phases on a nanoscale dimension that merges different nanoparticles togetherwith enormous or complicated materials, for example hybrid nanofibers and metal-organic frameworks. A composite of these nanomaterials can be a mixture of any polymer, ceramic or metal materials with any organic-based, inorganicbased, metal-based or carbon based nanomaterials [36]. These nanomaterials have potency to revolutionizes the manner at which diseases such as cancer are diagnosed and treated.

\subsection{Current Trends and Potentials of Nanomedicines}

Nanotechnology poses the potential to provide enormous opportunities for advancing medical science over various disciplines. At present, it is used fundamentally due to its importance in most significant inventions in medical treatments. Drug delivery accounts for a considerable portion in nanotechnology advances such as dendrimers, polymeric micelles and liposomes. These drug delivery systems have been used and proven to enhance delivery of various drugs. Disciplines that have gained benefits from nanotechnology advances include drug delivery, surgical treatment, diagnostic imaging and theranostics [26,38-40]. Some of the most successful examples of approved nanomedicines include Doxil/Caelyx (liposomal doxorubicin), Abraxane (nanoparticle albumin-bound paclitaxel) and ferumoxytol (iron oxide nanoparticle) [41-43].

The application of nanotechnology can be further extended to deliver multiple therapeutic agents in co-loaded nanoparticles, with the most recently approved example being VYXEOS. VYXEOS is a liposomal formulation of daunorubicin and cytarabine at a synergistic molar ratio of 1:5 approved by the FDA for the treatment of acute myeloid leukemia [22]. The pharmacological rationale behind VYXEOS development is to deliver both drugs effectively at the synergistic ratio directly to the leukemic cells, as in vitro and in vivo studies have shown that maximal synergy is achieved when tumor cell lines are exposed to five times as much cytarabine as daunorubicin [44]. However, this efficacious molar ratio could not be adequately achieved and maintained via the traditional $7+3$ regimen of administering cytarabine and daunorubicin individually, as each drug exhibits suboptimal pharmacokinetics and different rates of metabolism [45]. The clinical success of VYXEOS laid the foundation for more research of nanoparticle-mediated combination therapy to achieve synergistic therapeutic outcomes. In fact, the concept of co-delivery has been extended from combinations of two chemotherapeutic drugs to the co-delivery of chemotherapeutic drugs and gene therapy, immunotherapy, chemosensitizers or imaging agents for maximized therapeutic effects [46-51]. Furthermore, the ability to co-deliver therapeutic agents efficiently also proved to be effective in overcoming multidrug resistance (MDR) tumors [52,53]. Interestingly, nanotechnology has also been employed in the development of the BioNTech/Pfizer (BNT162b2) and Moderna (mRNA-1273) COVID-19 mRNA vaccines, which encapsulated the mRNA vaccine within lipid nanoparticles [54,55]. Furthermore, the striking ability of the vaccines to enter clinical trials rapidly, approximately 3 months after obtaining SARS-CoV-2 genome sequences, and the ability to manufacture billions of doses of high-quality vaccine annually further highlight the impressive potential of nanotechnology [56,57].

The continuous improvement of nanotechnology has also introduced new innovations to improve surgical treatments, including cancer surgery. A significant problem in many aggressive cancers, including breast cancer, lung cancer, brain cancer and sarcoma is the presence of minimal residual disease (MRD) despite appearing to achieve complete remission (CR) after initial treatment. MRD is defined as cancer persisting in a patient after treatment, and often comprises just tens of cancer cells that cannot be detected by current medical imaging techniques, resulting in increased risk of lethal relapse later [58]. Hormone receptor-positive breast cancer is the typical example of cancer frequently associated with late recurrence, which can occur after 20 years [59]. To remove potential MRD, surgeons routinely resect a large margin of normal tissue surrounding the tumor, which increases 
surgical morbidity. To address this issue, a laser pulse-activated nanoevent, called the plasmonic nanobubble, was developed to provide real-time intraoperative in vivo detection of MRD to guide precise and selective surgical resection of MRD with minimal damage to adjacent normal tissues [60]. Plasmonic nanobubbles are bubbles generated when metallic nanostructures convert light energy into highly localized heat that overheats liquid in their proximity, leading to a liquid-vapor phase transition and formation of vapor nanobubbles [61]. While this innovative nanotechnology has yet to be tested clinically, this unique on-demand threshold-activated transient nanoevent offers a new avenue for investigation in other applications, including diagnostics, therapy and theranostics.

\subsection{Application of Nanotechnology in Drug Delivery}

2.2.1. Improved Bioavailability

Drug administration through the oral route has historically been the preferred route of administration, especially in chronic illnesses which require repeated dosing, as it is simple, convenient, economical and non-invasive, thus contributing to the greatest degree of patient compliance $[62,63]$. However, effective oral drug delivery is often limited by various obstacles, including physicochemical barriers, biopharmaceutical barriers, physiological barriers and clinical barriers [64]. Many bioactive molecules from the natural sources have a high molecular size, resulting in a poor ability to cross the lipid membrane and poor absorption capacity, ultimately leading to reduced bioavailability and efficacy [65]. As such, several nanotechnology-based systems have been applied to improve the bioavailability of oral drugs. Among all the different nanoformulations, lipid-based nanoformulations have shown immense promise due to their ability to enhance the stability, solubility and permeability in the gastrointestinal tract $[66,67]$. Lipid nanocarriers were shown to enhance the oral bioavailability of hydrophilic and hydrophobic drugs in animals, including anticancer drugs [68-71], antiviral drugs [72,73], cardiovascular drugs [74], central nervous system drugs [75,76] and peptides [77]. Despite these promising in vivo results, several obstacles remain to be addressed, particularly understanding the mechanism of lipid-based nanoparticles absorption in order to overcome the bottleneck to the development of oral nanomedicines [66].

\subsubsection{Passive and Active Targeting}

A central paradigm behind intensive research on cancer nanomedicines has been the concept of preferential extravasation and the accumulation of nanoparticles within the tumor interstitium, a phenomenon described as the enhanced permeability and retention (EPR) effect [78]. This concept is justified by the observation that the inter-endothelial gaps in the tumor blood vessels formed during disorganized angiogenesis have a range of up to $2000 \mathrm{~nm}$ [79]. In addition, the EPR effect also relates to the findings that solid tumours tend to have a deficient functional intratumoral lymphatic system to remove extravasated nanoparticles [80]. Therefore, scientists are exploiting the EPR effect in the design of nanoparticles to induce passive transport and the accumulation of drugs in the tumor. Studies have reported that up to $10-15 \%$ of injected nanoparticles accumulate at the tumor site in vivo, as compared to $0.1 \%$ of the injected free drug, which may be attributed to the EPR effect $[81,82]$.

However, this predominant concept is being increasingly challenged by the nanotechnology community recently due to the poor clinical translation of nanomedicines after three decades of research [83]. A recent study addressed this question by performing imaging techniques and computational analysis to study the transport mechanism of nanoparticles into solid tumors. The study found that the frequency of inter-endothelial gaps is far less abundant to account for the nanoparticle accumulation in the tumor. The study reported that nanoparticles enter tumors mainly through active transcytosis by endothelial cells [84]. Furthermore, a meta-analysis of preclinical studies published over the past ten years revealed that only a median of $0.7 \%$ of nanoparticles' injected dose (\% ID) reaches the tumors in mice [82]. However, it is important to recognize the limitations of these 
studies and exercise caution in drawing general conclusions that de-emphasize the EPR effect, as the study by Sindhwani and colleagues only studied the extravasation of one type of nanoparticle at three sizes $(15 \mathrm{~nm}, 50 \mathrm{~nm}$ and $100 \mathrm{~nm}$ of colloidal gold). Besides, Wilhelm and colleagues evaluated the effectiveness of nanomedicines based on an unconventional parameter (\% ID) and did not consider traditional pharmacokinetic parameters such as peak drug concentration $\left(C_{\max }\right)$, clearance $(C L)$, elimination half-life $\left(t_{1 / 2}\right)$ and volume of distribution $\left(\mathrm{V}_{\mathrm{d}}\right)$ which are regularly used to govern regulatory approval of drugs [85]. Nevertheless, Sindhwani and colleagues provided compelling evidence that active transcytosis may act as the dominant transport mechanism of nanoparticles into tumors and motivates researchers to revisit the long-established paradigm and understand the mechanism governing extravasation.

Moreover, EPR effects are highly heterogenous and have been shown to vary over time during tumor development, differing substantially between animal models and patients, among different tumors from the same origin, and among tumors within the same individual [86]. The heterogeneity of EPR effects is the result of the heterogenous nature of intratumoral blood flow, variable vascular permeability, lymphatic drainage network, interstitial tissue pressure, density and composition of the extracellular matrix (ECM) [87-89]. These intrinsic heterogeneities of tumors in patients were observed primarily in large clinical tumors than in smaller tumours and have greatly impeded successful clinical translation of nanomedicines [90]. Thus, it may be inappropriate to draw conclusions that underestimate the potential of EPR effects in nanomedicines before understanding the interactions that influence the fate of nanoparticles in biological systems. In fact, the strategy of applying EPR-effect enhancers has been increasingly discussed, including physical methods and pharmacological agents to induce vessel permeabilization, normalization, disruption and promotion [86,90-93]. The importance of patient stratification has also been highlighted, recognizing that clinical trials of patients with high or low levels of EPR will lead to vastly different therapeutic outcomes [31,86]. Recent studies have employed ferumoxytolenhanced magnetic resonance imaging (MRI) to quantify and characterize tumor-EPR heterogeneity, where higher levels of ferumoxytol accumulation are correlated with greater lesion size reduction following Onivyde treatment $[94,95]$. Furthermore, the pessimistic conclusions that EPR effects are absent in humans may be due to poorly designed nanoparticles, particularly those with a low plasma half-life $\left(t_{1 / 2}\right)$ or active pharmaceutical ingredients (API) that are readily converted free low molecular weight drugs [91]. In contrast to passive targeting, active targeting involves grafting the nanoparticle surface with specific targeting ligands, including antibodies, antibody fragments, peptides, aptamers and folic acid to direct the nanoparticles to the receptors or antigens expressed at the cancer cell surfaces and enhance tumor accumulation [96-101]. This requires an extensive understanding of the specific characteristics of the tumor site and receptor structures of the targeted disease cells. These targeting ligands facilitate selective internalization of nanoparticles into cancer cells via selective receptor-mediated endocytosis, allowing enhancement of cytotoxic activity while avoiding adverse effects on non-cancerous tissues [102,103]. Some of the most widely used ligands in cancer nanomedicines include transferrin, hyaluronic acid, folic acid and arginine-glycine-aspartate (RGD) peptide [104-106]. Furthermore, surface functionalization of nanoparticles with targeting ligands also endows them with the ability to traverse physiological barriers such as intestinal mucosa and the blood-brain barrier [26,107-109]. However, it is important to understand that targeted nanoparticles still rely on EPR effects to extravasate and reach the tumor cells [93]. This may be the reason why targeted nanoparticles do not radically improve the biodistribution of nanomedicines, and active targeting is often seen as a complementary approach to EPR to improve the efficacy of nanomedicines [78]. In fact, studies comparing the accumulation of nanoparticles in tumors did not observe significant difference between EPR-mediated passive targeting and peptide-mediated or transferrin-mediated active targeting [110-112]. Despite the advantages reported for active targeting, only limited actively targeted nanoparticles have reached clinical trials, and none have advanced past clinical trials [83]. Some 
examples of promising targeted nanomedicines in clinical trials include the BIND-014 prostate-specific membrane antigen (PSMA)-targeted docetaxel nanoparticle for metastatic prostate cancer (Phase 2 completed) [113,114], SGT-53 anti-transferrin receptor single chain antibody fragment (anti-TfR-scFv) liposomal nanoparticle delivering wild-type p53 gene for advanced solid tumor (Phase 2 ongoing; NCT02340117) [115], SGT-94 anti-TfR-scFv liposomal nanoparticle delivering RB-94 gene for metastatic genitourinary cancer (phase 1 completed) [116] and anti-epidermal growth factor receptor (anti-EGFR) immunoliposomes loaded with doxorubicin (anti-EGFR ILs-dox) for advanced solid tumor (phase 2 ongoing; NCT02833766) [117]. Another very promising approach of targeted drug delivery involves magnetic targeting to target drugs precisely to desired tumor regions with the aid of magnetic nanoparticles guided by the external magnetic field $[118,119]$. Interestingly, the lipid-based nanocarriers showed enhanced radiation and chemotherapy-induced immunogenic cell death as well [120].

With these aforementioned benefits and innovations provided by nanotechnology in drug delivery (Figure 1), numerous opportunities are presented to improve the biomedical applications of natural products, which are generally characterized by low aqueous solubility and chemical instability that severely hinder their formulations into parenteral drugs. Furthermore, a considerable portion of natural products have poor intestinal permeability and bioavailability which limit their development into oral drugs [121]. In fact, the alkaloids such as paclitaxel and docetaxel are categorized as Class IV drugs (low solubility-low permeability) under the Biopharmaceutics Classification System (BCS) [122]. The detailed limitations of alkaloids are discussed in Section 3.2. These limitations, together with the rapid emergence of targeted therapies, have led to the marginalization of anticancer natural products by pharmaceutical companies [123]. However, the exciting advances in nanotechnology for drug delivery have spurred new opportunities to reformulate natural products and rekindled interest in anticancer natural products, especially alkaloid compounds.
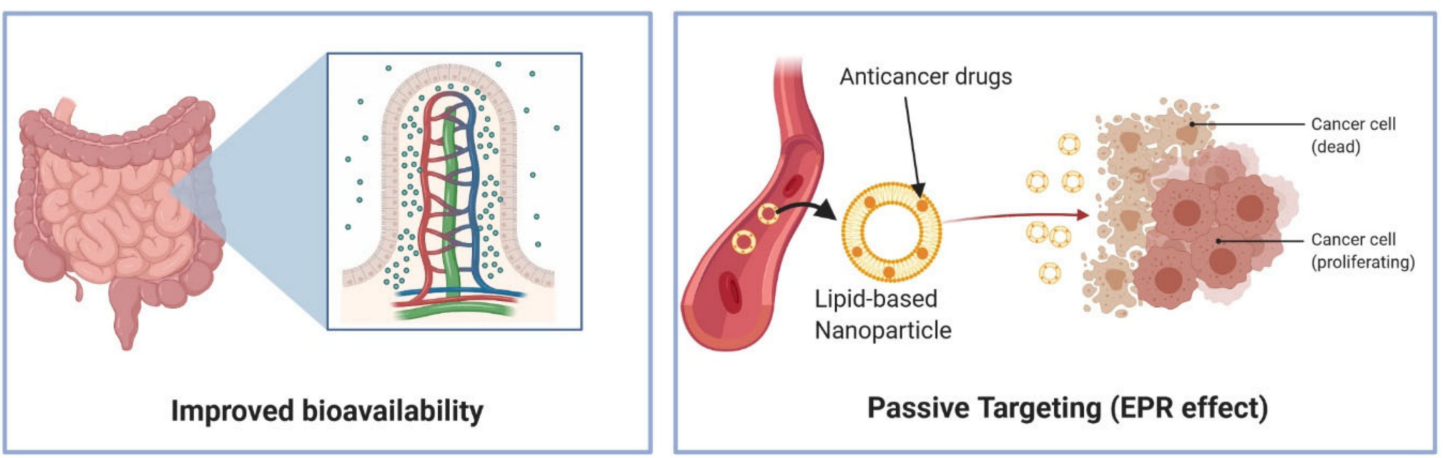

Figure 1. Cont. 


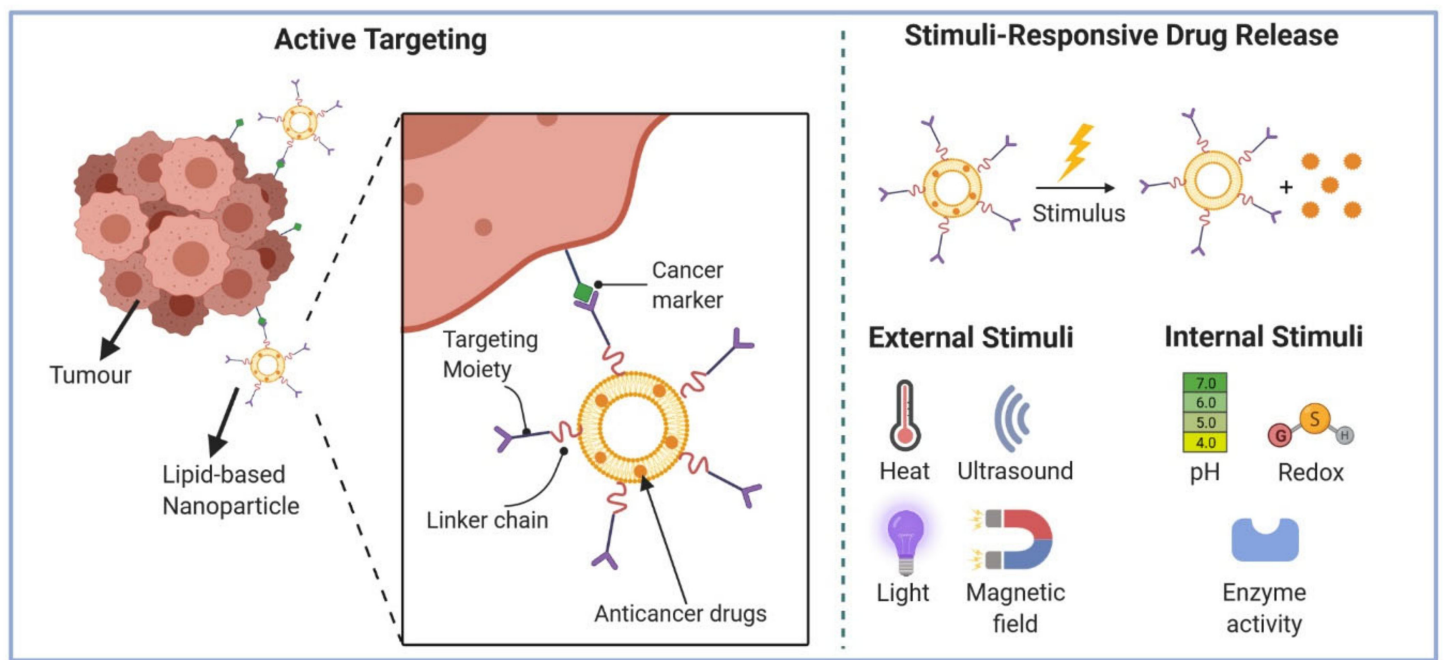

Figure 1. Advantages of nanoparticles in drug delivery. The nanosized drugs demonstrated immense promise due to their ability to enhance the stability, solubility and permeability in the gastrointestinal tract. Apart from the passive targeting by enhanced permeability and retention effect, the nanoparticles can also be formulated by targeting moiety such as an antibody to enhance the drug targeting. External and internal stimuli could also be employed to trigger the drug release at the specific site and specific time, thereby enhancing the drug-targeting properties.

\section{Alkaloid}

Alkaloids are ubiquitous in nature. They are mostly found in plants, and can also be produced by terrestrial animals, marine organisms, microorganisms such as bacteria, fungi and insects. Approximately $20 \%$ of plant species contain alkaloids, most of which are biosynthetically derived from amino acids lysine (Lys), ornithine (Orn), tryptophan (Trp), tyrosine (Tyr) and phenylalanine (Phe) [124].

Alkaloid is a class of naturally occurring heterocyclic organic compounds that contain a nitrogen atom. With over 20,000 structurally characterized members, alkaloids remain one of the most medicinally important classes of compounds with a wide range of pharmacological activities, often considered privileged structures in drug discovery [10,11]. In fact, the first naturally derived pure medicine was morphine, an alkaloid isolated from opium poppy in 1805 and commercialized by Merck in 1826 [13]. Since then, numerous alkaloids have been isolated and exploited effectively for the betterment of mankind.

Due to its vast structural diversity and widespread distribution in nature, several classification systems have been used to classify alkaloids, including chemical classification, taxonomic classification, pharmacological classification and biosynthetic classification, each with their own strengths and limitations. In this review, we have adopted the chemical classification to classify the alkaloids based on their chemical structures as this is the most established classification scheme for alkaloids. On this classification basis, the main classes of alkaloids in our review are indole, quinoline, isoquinoline, pyrrolidine, pyridine, piperidine, tropane, indolizidine, terpenoid, purine, imidazole and steroidal alkaloids. Table 1 summarizes different types of medicinally significant alkaloids according to the chemical classification. 
Table 1. Medicinally Significant Alkaloids According to the Chemical Classification.

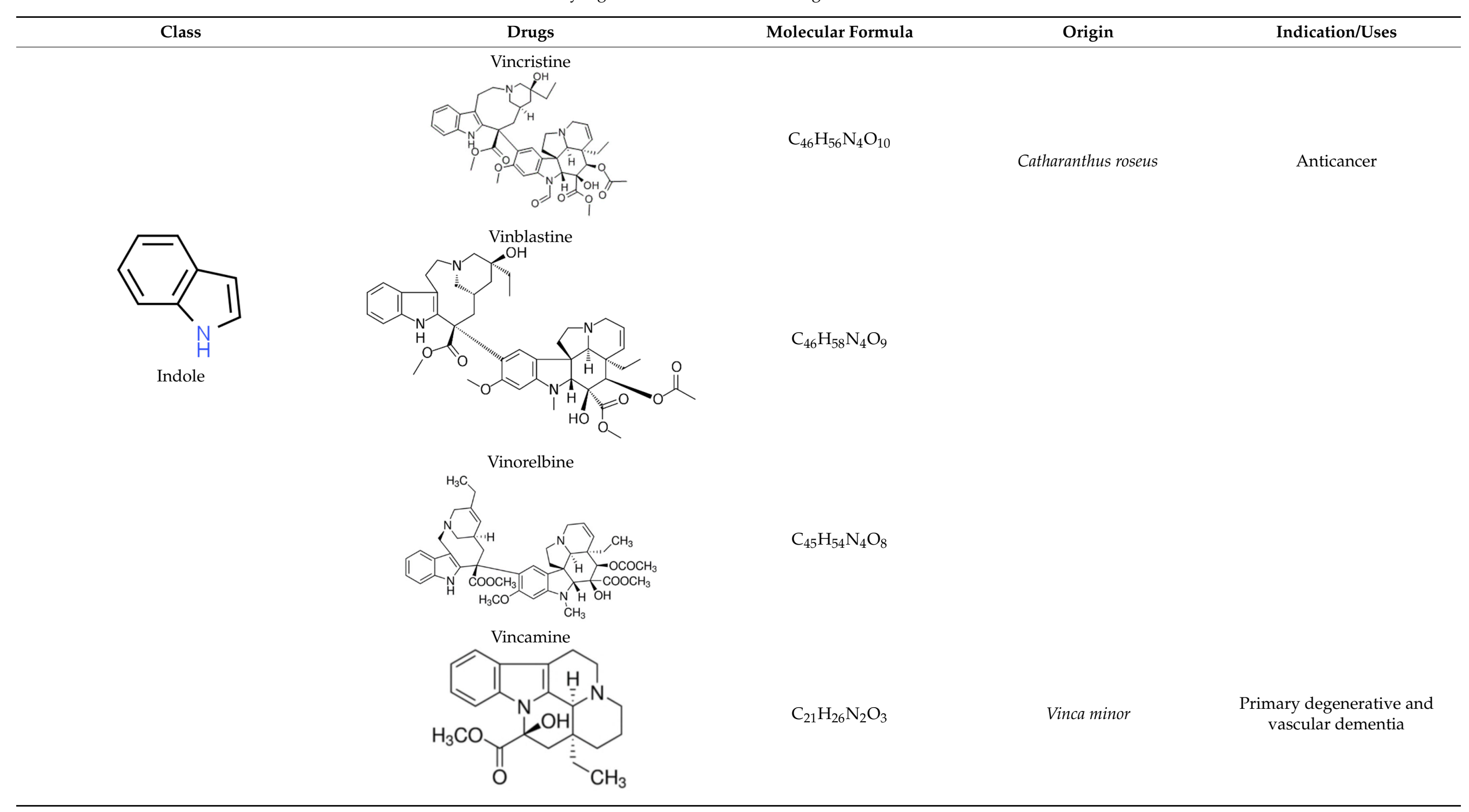


Table 1. Cont.

\section{Class}

Drugs

Molecular Formula

Origin

Indication/Uses

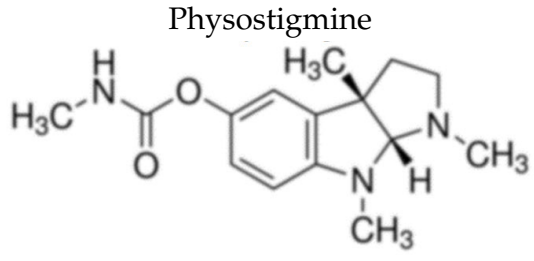

$\mathrm{C}_{15} \mathrm{H}_{21} \mathrm{~N}_{3} \mathrm{O}_{2}$

Physostigma venenosum

Glaucoma

Ajmaline

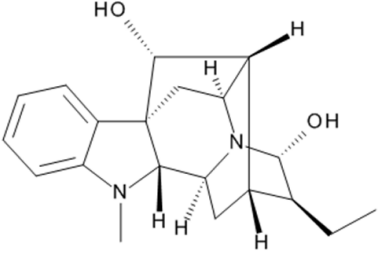

$\mathrm{C}_{20} \mathrm{H}_{26} \mathrm{~N}_{2} \mathrm{O}_{2}$

Rauvolfia serpentina

Anti-arrhythmic

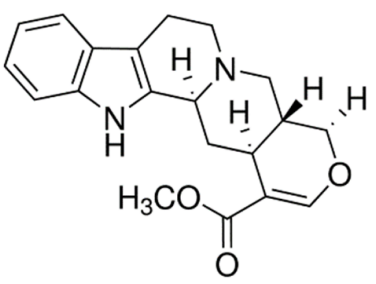

$\mathrm{C}_{21} \mathrm{H}_{24} \mathrm{~N}_{2} \mathrm{O}_{3}$

Anti-hypertensive

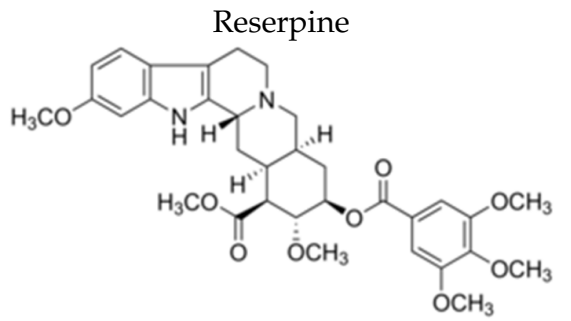

$\mathrm{C}_{33} \mathrm{H}_{40} \mathrm{~N}_{2} \mathrm{O}_{9}$

Rauvolfia serpentina

Anti-hypertensive 
Table 1. Cont

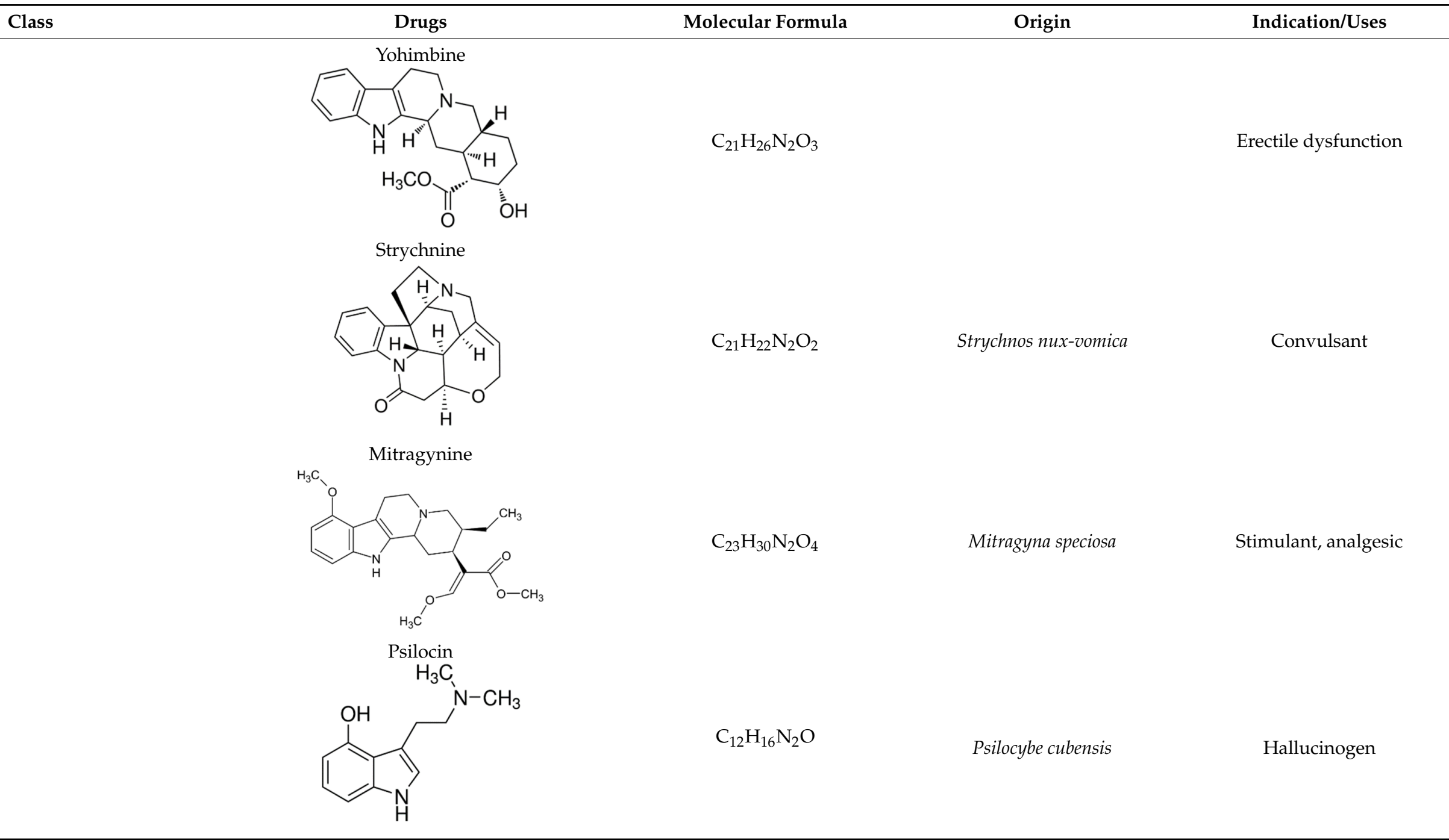


Table 1. Cont.

Class

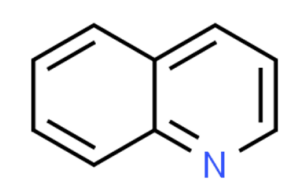

Quinoline

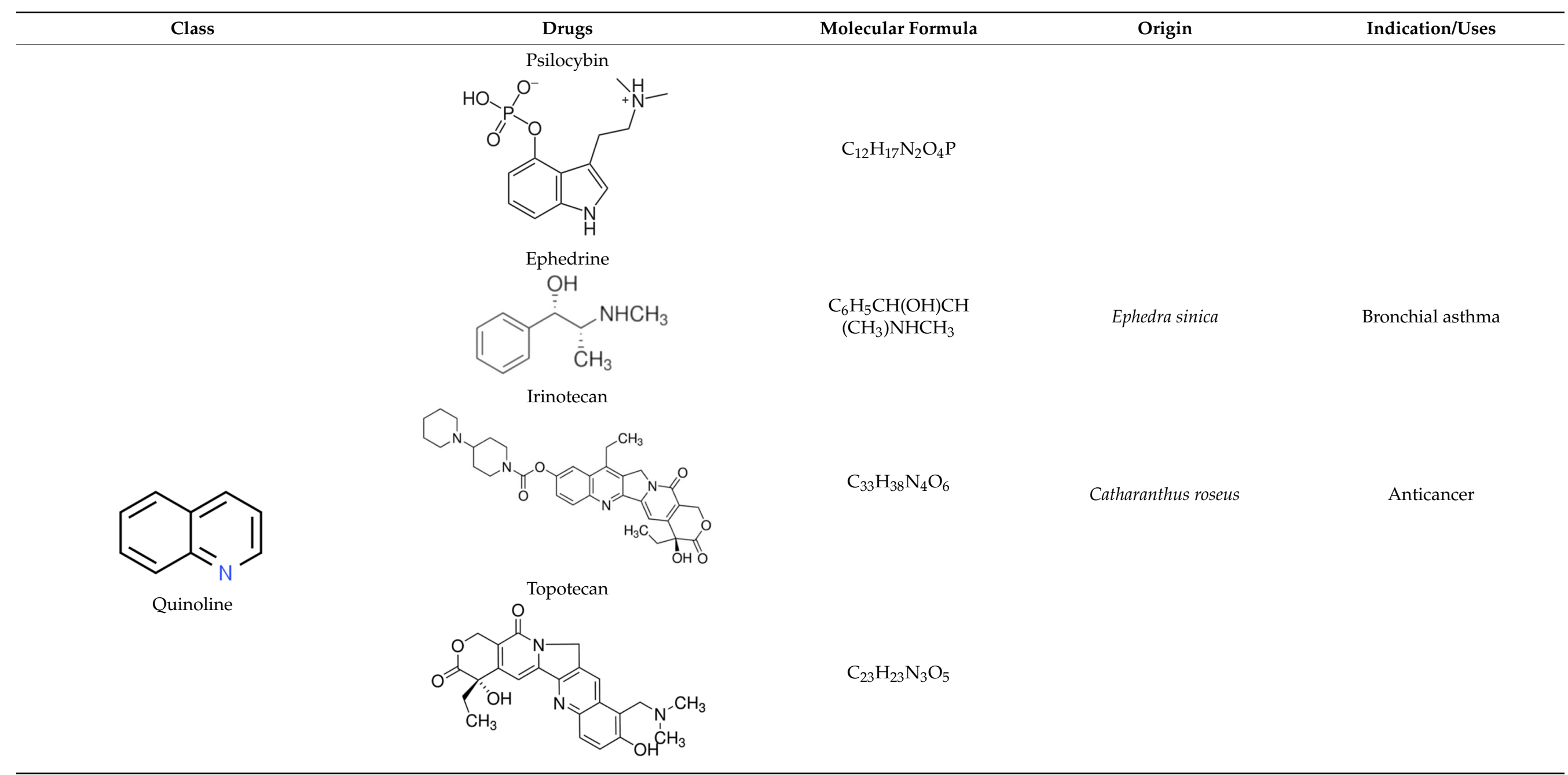


Table 1. Cont.

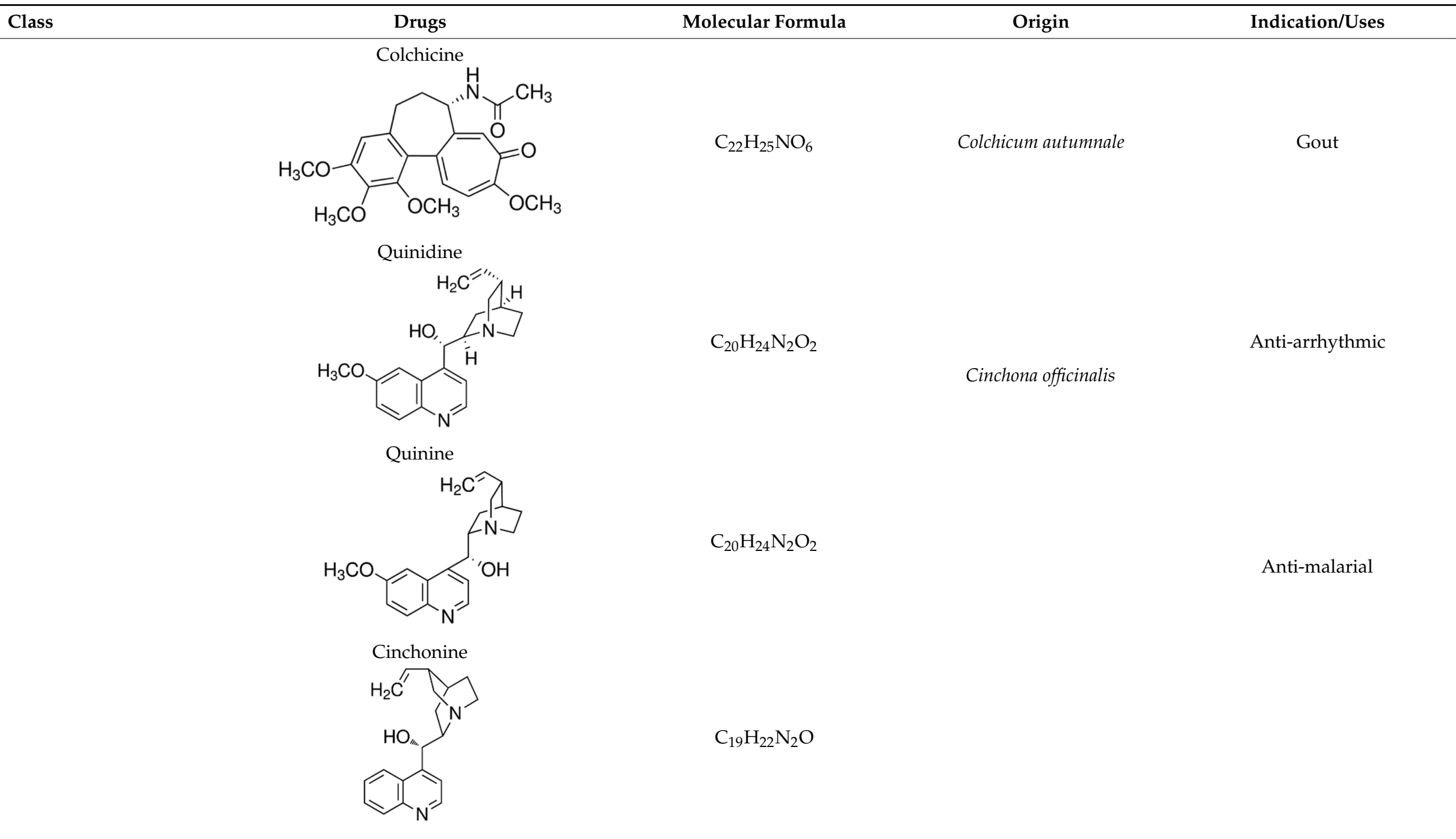


Table 1. Cont.

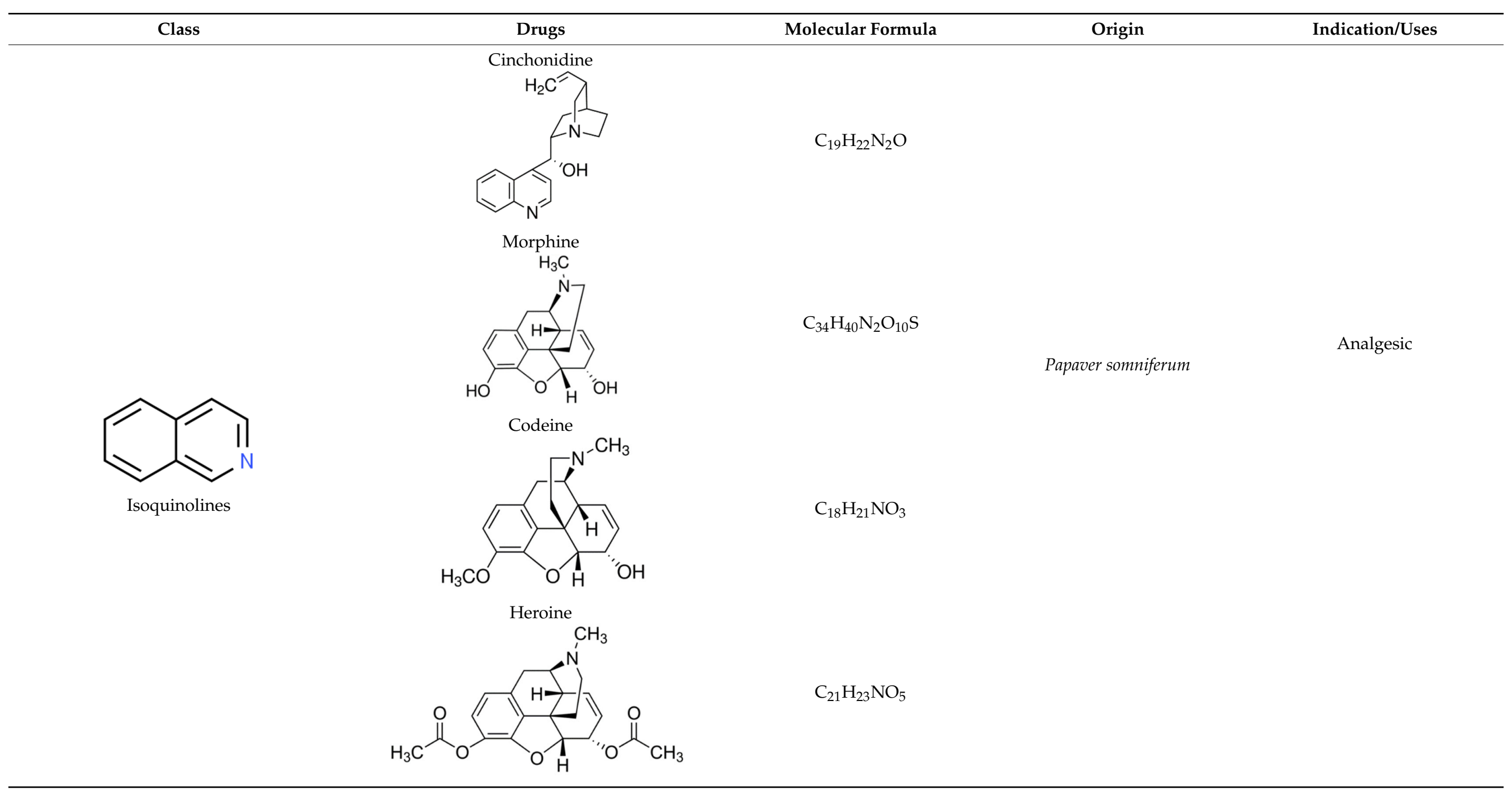


Table 1. Cont.

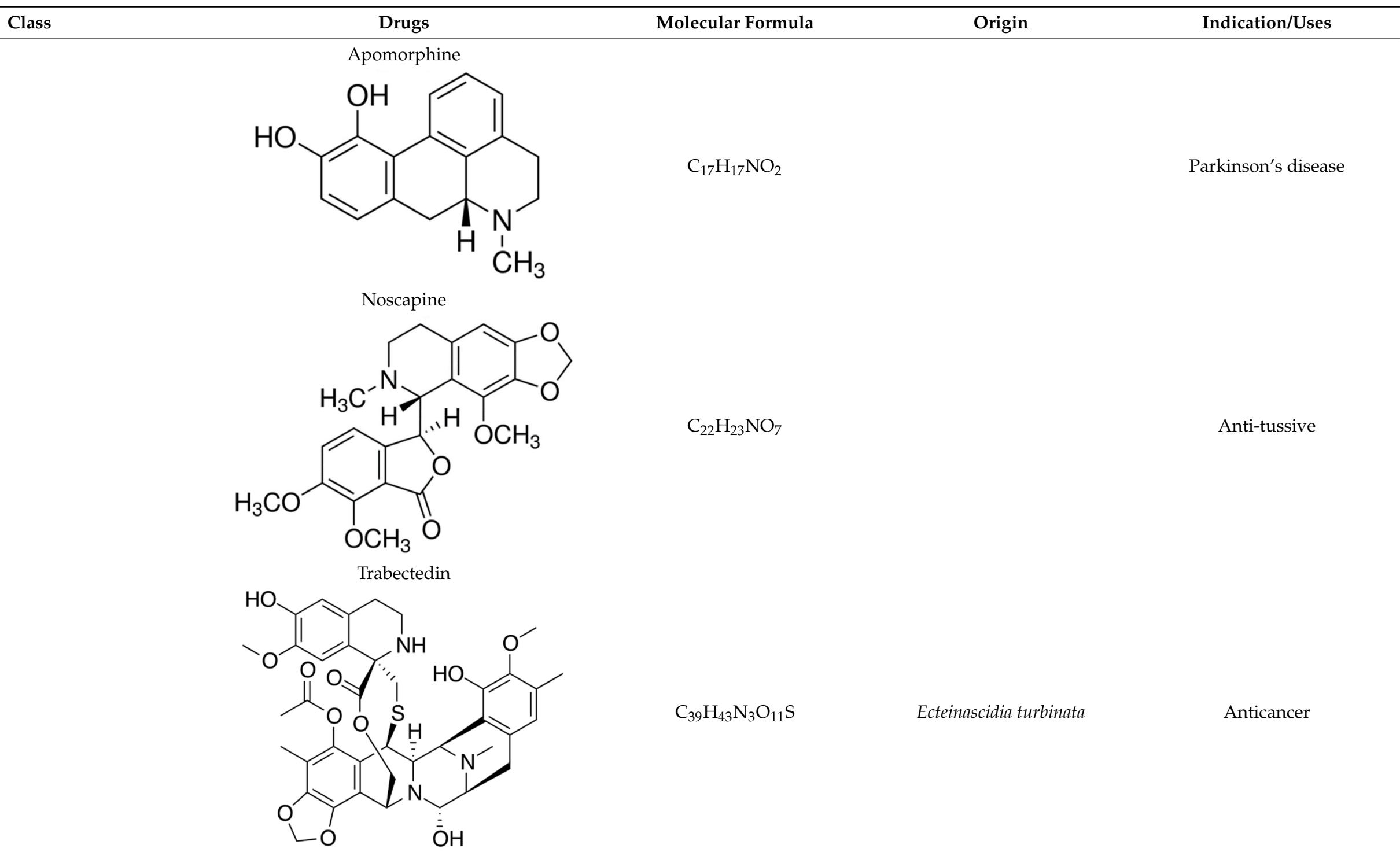


Table 1. Cont

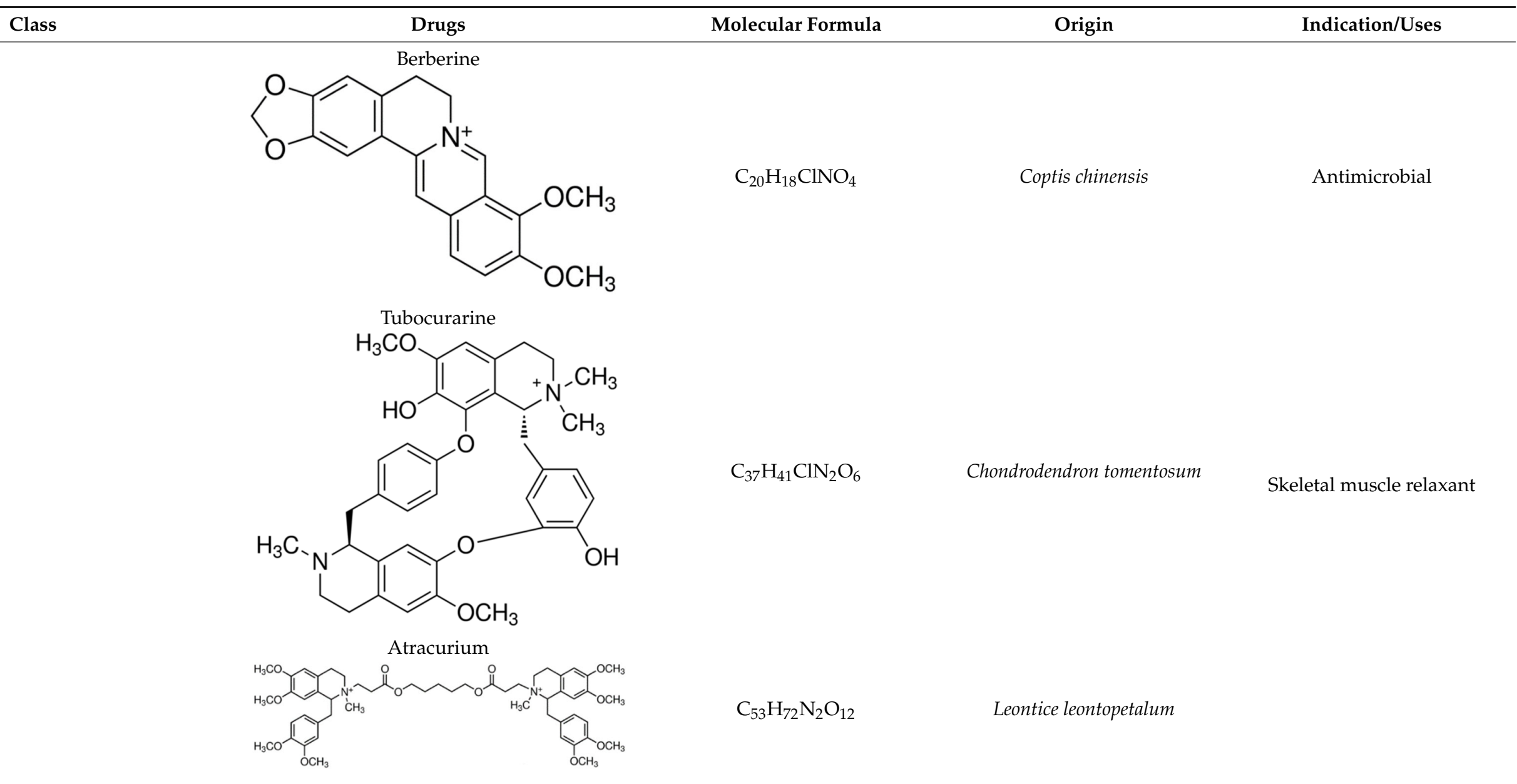


Table 1. Cont.

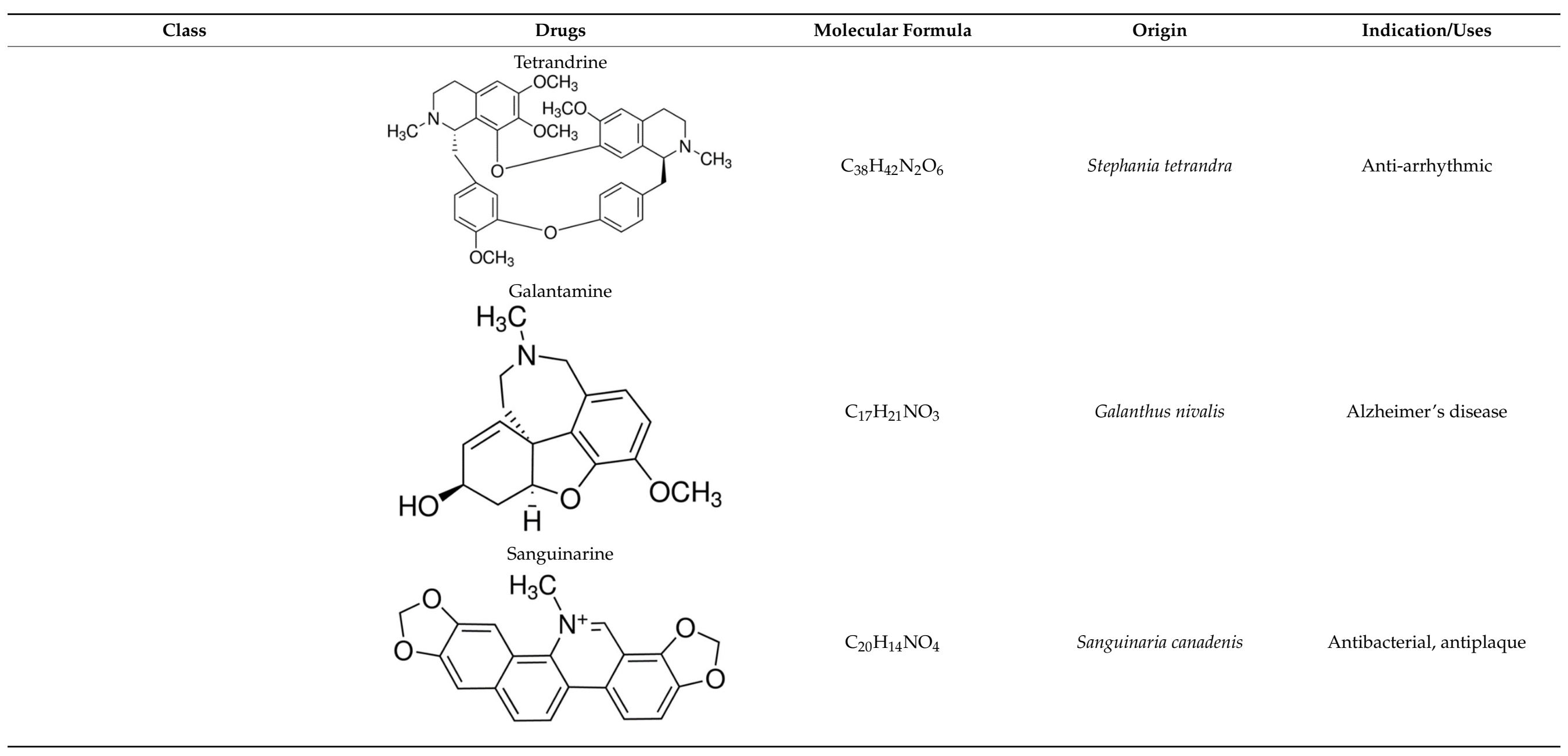


Table 1. Cont.

\section{Class}

Drugs

Papaverine
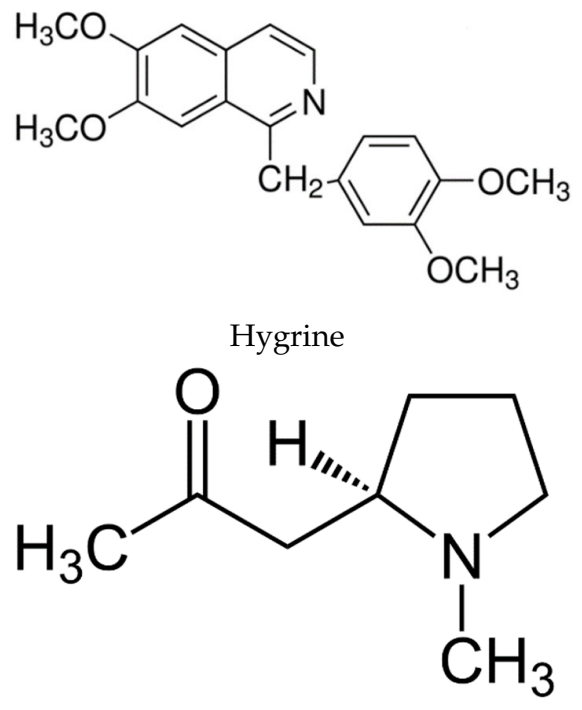

Cuscohygrine<smiles>CN1CCC[C@H]1CC(=O)C[C@@H]1CCCN1C</smiles>

Stachydrine

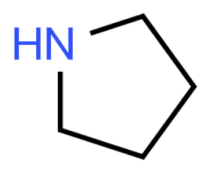

Pyrrolidines
Molecular Formula

Origin

Indication/Uses

$\mathrm{C}_{20} \mathrm{H}_{21} \mathrm{NO}_{4}$

Papaver somniferum

Vasodilator

$\mathrm{C}_{8} \mathrm{H}_{15} \mathrm{NO}$

Erythroxylon coca

Laxative, diuretic

$\mathrm{C}_{13} \mathrm{H}_{24} \mathrm{~N}_{2} \mathrm{O}$

$\mathrm{C}_{7} \mathrm{H}_{14} \mathrm{NO}_{2}$ 
Table 1. Cont.

\section{Class}

Drugs

Molecular Formula

$\mathrm{C}_{8} \mathrm{H}_{13} \mathrm{NO}_{2}$

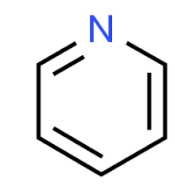

Pyridines

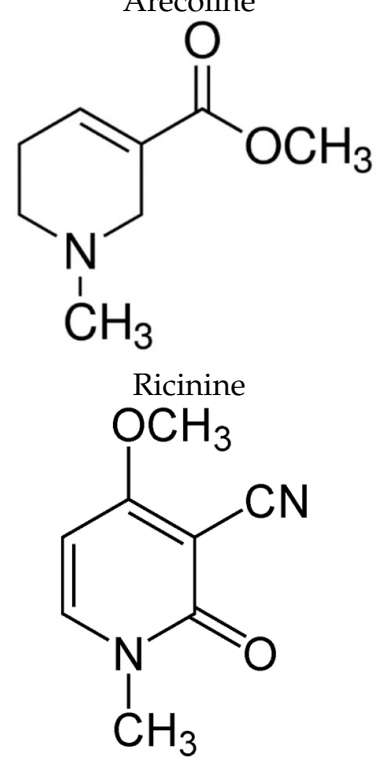

Trigonelline<smiles>C[n+]1cccc(C(=O)O)c1</smiles>

Origin

Indication/Uses

$\mathrm{C}_{8} \mathrm{H}_{8} \mathrm{~N}_{2} \mathrm{O}_{2}$

Ricinus communis

Insecticide

$\mathrm{C}_{7} \mathrm{H}_{7} \mathrm{NO}_{2}$

Trigonella foenum-graecum

Antidiabetic 
Table 1. Cont.

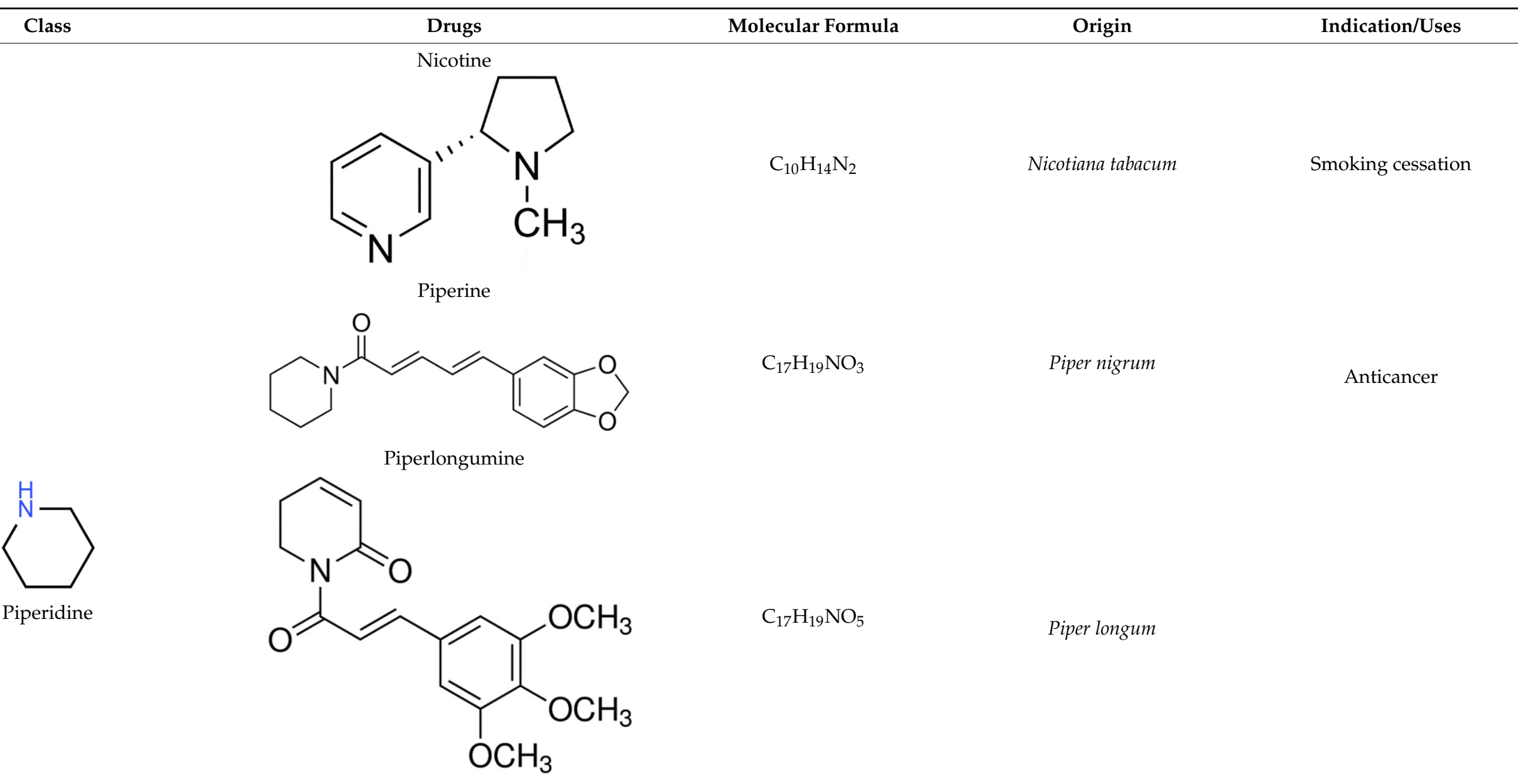


Table 1. Cont.

\begin{tabular}{|c|c|c|c|c|}
\hline Class & Drugs & Molecular Formula & Origin & Indication/Uses \\
\hline & & $\mathrm{C}_{21} \mathrm{H}_{27} \mathrm{NO}_{3}$ & & Antifungal \\
\hline & & $\mathrm{C}_{17} \mathrm{H}_{23} \mathrm{NO}_{3}$ & Atropa belladonna & Anticholinergic \\
\hline & & $\mathrm{C}_{17} \mathrm{H}_{21} \mathrm{NO}_{4}$ & Erythroxylum coca & Local anaesthetic \\
\hline & & $\mathrm{C}_{17} \mathrm{H}_{23} \mathrm{NO}_{3}$ & $\begin{array}{c}\text { Atropa belladonna, Hyoscyamus } \\
\text { niger }\end{array}$ & Anticholinergic \\
\hline
\end{tabular}


Table 1. Cont.

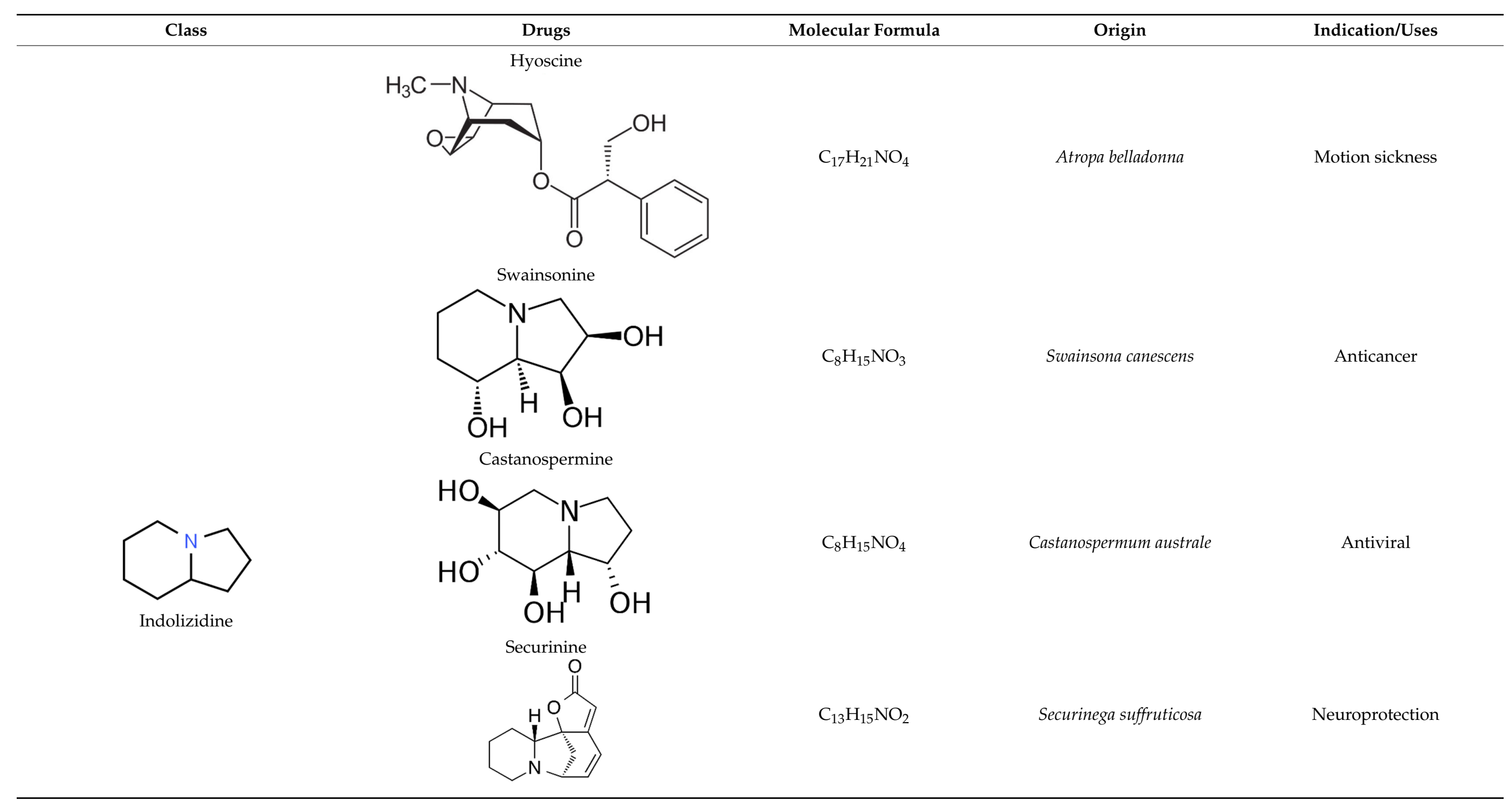


Table 1. Cont.

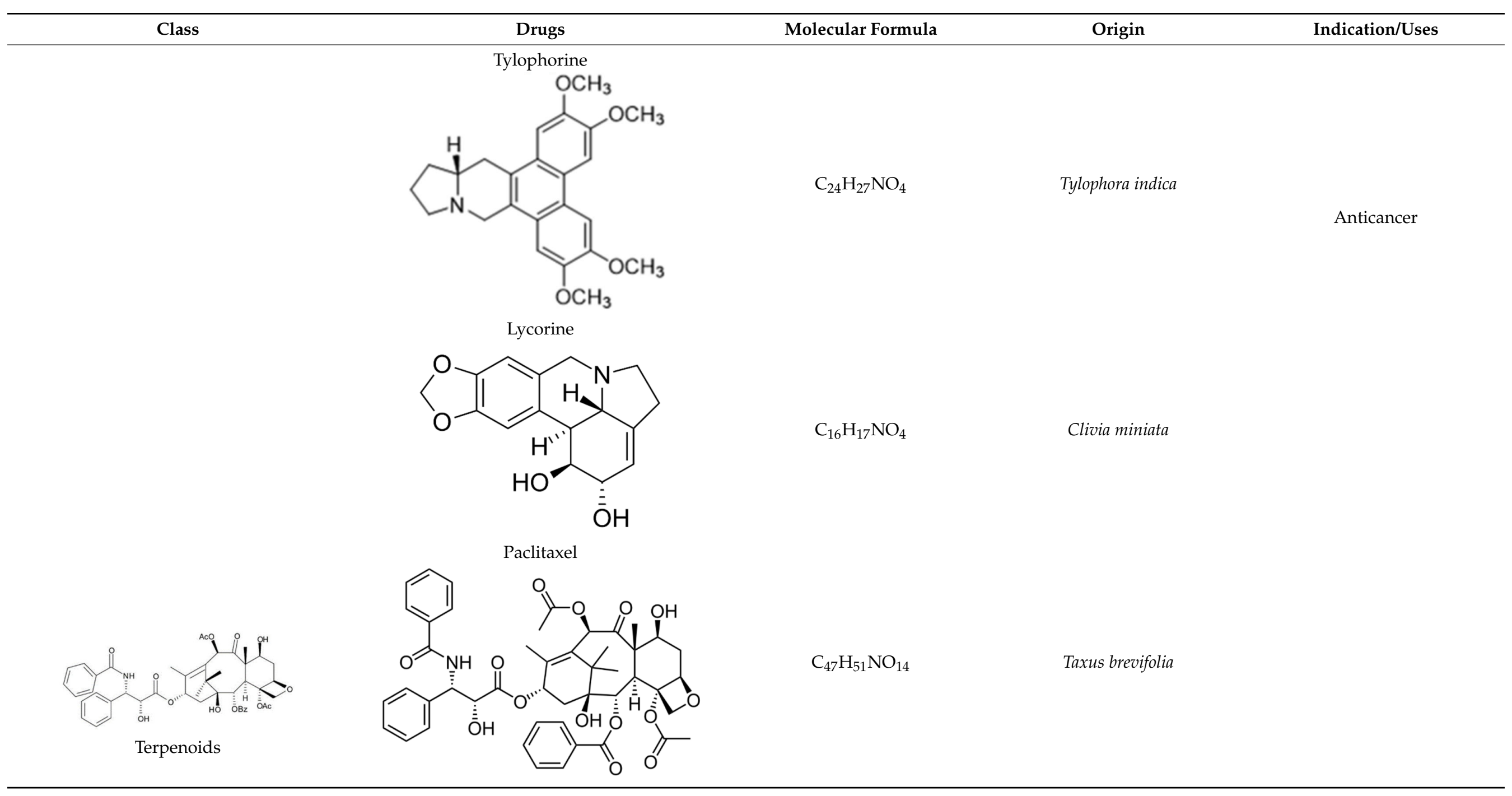


Table 1. Cont.

\begin{tabular}{|c|c|c|c|c|}
\hline Class & Drugs & Molecular Formula & Origin & Indication/Uses \\
\hline & & $\mathrm{C}_{43} \mathrm{H}_{53} \mathrm{NO}_{14}$ & Taxus baccata & \\
\hline & & $\mathrm{C}_{8} \mathrm{H}_{10} \mathrm{~N}_{4} \mathrm{O}_{2}$ & Coffee arabica & CNS stimulant \\
\hline & & $\mathrm{C}_{7} \mathrm{H}_{8} \mathrm{~N}_{4} \mathrm{O}_{2}$ & Theobroma cacao & Cardioprotectant \\
\hline
\end{tabular}


Table 1. Cont.

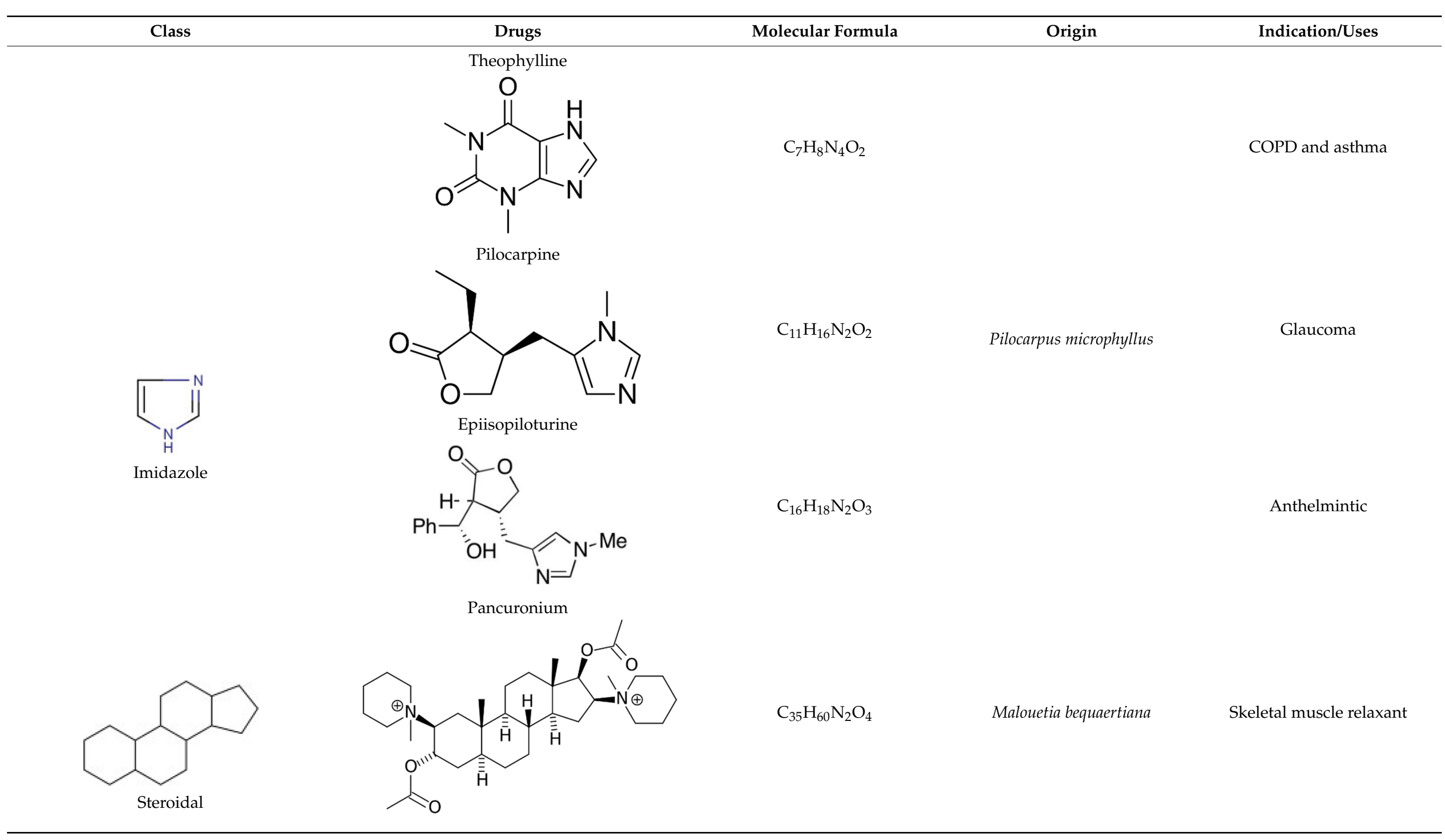


Table 1. Cont.

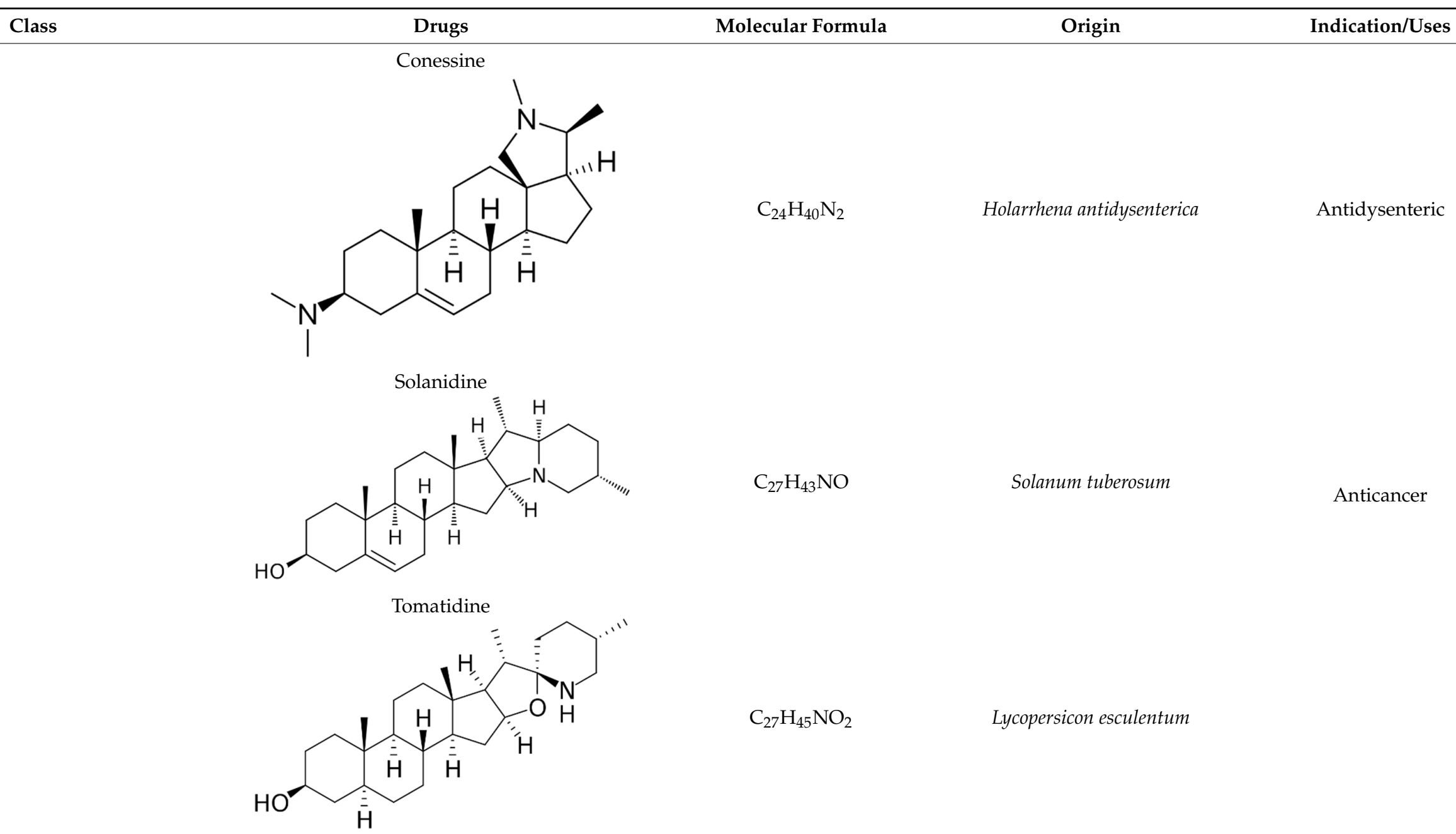


Today, alkaloid drugs have been approved by the FDA for the treatment of cancer, Alzheimer's disease, Parkinson's disease, migraine, pain control, erectile dysfunction, heart failure and many more [12]. Alkaloids have been widely utilized in various solid tumors and hematological malignancies as a monotherapy or in combination with other chemotherapeutic drugs [125-129]. Thus, much effort has been devoted to elucidate and decipher the mechanism of action of these anticancer alkaloids.

\subsection{Anti-Cancer Properties of Alkaloids}

The remarkable progress in understanding the nature of cancer has allowed us to rationalize the vast complexity of cancer pathogenesis and identify a few major hallmarks of cancer acquired by practically all lethal cancers [130-132]. Several alkaloids have demonstrated excellent activity in targeting these cancer hallmarks and are currently being investigated in preclinical studies, and some have successfully entered the clinics as chemotherapeutic drugs. The most notable anticancer alkaloids that continue to maintain palpable significance in clinical practice include paclitaxel, docetaxel, vincristine, vinblastine, irinotecan and topotecan.

Alkaloids have demonstrated the ability to eradicate cancer cells by overcoming their ability to sustain proliferation and evade apoptosis by suppressing microtubules dynamics. Microtubules are cytoskeletal filaments that permeate the cytoplasm of all eukaryotic cells and play a pivotal role in numerous biological processes, including intracellular transport, cell motility, cell morphology maintenance and formation of mitotic spindle to facilitate chromosome separation during cell division [133-137]. Microtubules are inherently dynamic and capable of organizing and restructuring into different architectures in precise timing and location to facilitate various cellular functions [138,139]. During mitosis, the microtubule dynamics are increased by $20-100$-fold [140]. As such, microtubules are important targets for anticancer drugs. Natural products targeting microtubules, including alkaloids, have demonstrated remarkable effectiveness in the treatment of both solid tumors and hematological malignancies [141]. Microtubule-targeting agents are broadly classified into microtubule-stabilizing agents (taxanes) and microtubule-destabilizing agents (vinca alkaloids) [15].

Taxanes such as paclitaxel and docetaxel are microtubule-targeting agents that work by stabilizing microtubule dynamics to inhibit cell entry into mitosis. They bind to $\beta$-tubulin and promote the polymerization of microtubules to form stable microtubules, resulting in the disruption of microtubule dynamics [142-144]. By interfering with microtubule dynamics, paclitaxel and docetaxel inhibit mitotic spindle formation, arrest cancer cells in the metaphase of mitosis, and eventually trigger apoptotic cell death through mitotic catastrophe [15,145]. Taxane-induced mitotic spindle defect induces chronic activation of the spindle assembly checkpoint (SAC) to arrest the metaphase-to-anaphase transition until chromosomes are properly attached and aligned to the spindle microtubules [146]. Chronic SAC activation inhibits ubiquitination and proteasomal degradation of cyclin B1 and chronically increases the activity of CDK1, resulting in sustained mitotic arrest in the G2/M phase $[147,148]$.

However, during mitotic catastrophe, a shift of the cellular response from mitotic arrest to apoptosis occurred through upregulation of the tumor necrosis factor (TNF)-like cytokine 1A (TL1A) that activates death receptor 3 (DR3). This subsequently initiates the recruitment of FADD and caspase-8 to form the death-inducing signaling complex (DISC), and activates the executioner caspases (caspase-3/-7) to execute extrinsic apoptosis [145]. Prolonged mitotic arrest due to persistent activation of SAC following taxanes treatment also leads to cell death via the intrinsic apoptosis pathway, which is regulated by the $\mathrm{B}$ cell lymphoma-2 (BCL-2) family [149-151]. Taxanes accumulate pro-apoptotic signals and inactivate anti-apoptotic proteins, resulting in the activation of BCL-2 effector proteins $\mathrm{BAX}$ and BAK. BAX and BAK oligomerize at the mitochondria and cause MOMP, inducing release of cytochrome- $c$ that promotes the formation of apoptosomes. This subsequently leads to the engagement of caspase- 9 , ultimately the activation of caspase- 3 and caspase- 
7 [152,153]. Paclitaxel has been reported to bind directly to BCL-2 in mitochondria and induce apoptosis [154]. A recent study reported that preventing SAC silencing through p31 $1^{\text {comet }}$ depletion enhanced paclitaxel-mediated apoptosis and markedly potentiated the cytotoxicity of paclitaxel [155].

Another major class of the microtubule-targeting agent is the microtubule-destabilizing agents. Similar to taxanes, vinca alkaloids (vincristine, vinblastine, vinorelbine, vindesine, vinflunine) are remarkable anticancer drugs that target $\beta$-tubulin [156]. However, instead of promoting the polymerization of microtubules to disrupt microtubule dynamics, vinca alkaloids bind to a different site of $\beta$-tubulin to depolymerize the microtubules [157]. Vinca alkaloids bind between two tubulin heterodimers near the exchangeable GTP site to inhibit the GTP to GDP hydrolysis and GDP-GTP exchange. This triggers a conformational change in tubulin heterodimers from straightened conformation favored for polymerization to curved conformation, lowering the amount of tubulin available for polymerization. This microtubule dynamics disruption prevents mitotic spindle from assembling normally and causes mitotic arrest at the metaphase [157-159]. Similar to taxanes, prolonged mitotic arrest caused by vinca alkaloids triggers mitotic catastrophe and induction of apoptosis through the intrinsic and extrinsic pathways in cancer cells $[145,160,161]$.

On the other hand, irinotecan and topotecan are highly potent semi-synthetic analogues of alkaloid camptothecin which have demonstrated wide-spectrum anticancer activity by inhibiting topoisomerase I and inducing catastrophic DNA damage [14]. DNA topoisomerases are ubiquitous and complex vital enzymes responsible for regulating fundamental DNA transactions such as replication, transcription, recombination and repair. Topological problems such as disordered DNA entanglements and knots may be generated during these DNA transactions which, if left unresolved, can lead to genomic instability. Topoisomerase I resolves these topological constraints that arise from RNA polymerase II activity by producing transient single-stranded nick, relaxing the strand and re-ligating the double-stranded DNA structure [162-164]. Topoisomerase I inhibitors irinotecan and topotecan stabilize and trap the topoisomerase I-DNA-cleaved complexes (TOP1cc), disabling the re-ligation of the nicked strand and preventing the release of topoisomerase. The trapped TOP1cc eventually collides with advancing replication forks, resulting in lethal and irreversible double-strand breaks and ultimately causes cancer cell death $[164,165]$.

In response to DNA double-strand breaks induced by topoisomerase I inhibitors, the DNA insults are sensed by the MRE11-RAD50-NBS1 (MRN) complex which promotes the activation of ataxia-telangiectasia mutated (ATM) kinase. ATM checkpoint signaling phosphorylates and activates checkpoint kinase 2 (Chk2), leading to cell cycle regulation. ATM together with Chk2 also phosphorylates p53, reducing p53 affinity to its negative regulator E3 ubiquitin ligase MDM2, and resulting in p53 stabilization. Once p53 is activated and stabilized, it acts as a transcription factor and induces the expression of genes involved in cell cycle arrest (p21) and apoptosis (Bax, PUMA, NOXA). This leads to the activation of protease activity of caspases of both intrinsic and extrinsic apoptosis pathways (caspase-8, caspase-9 and caspase-3/7) [166-168]. The MRN activation also induces activation of ataxia-telangiectasia and RAD3-related (ATR) kinase which phosphorylates checkpoint kinase 1 (Chk1), arresting the cell cycle in the S phase $[169,170]$.

\subsection{Limitations of Current Alkaloid Anticancer Drugs Formulation}

Despite all the unique anticancer mechanism of actions demonstrated by alkaloids via modulation of several pathways, the full potential of currently available alkaloids and the commercialization of potential anticancer alkaloids could not be achieved due to their lack of specificity to cancer cells, indiscriminate tissue distribution, dose-limiting side effects and toxic formulation excipients $[16-18,171]$. This section summarizes the limitations of taxanes (paclitaxel and docetaxel), vinca alkaloid (vincristine) and topoisomerase I inhibitor (irinotecan) to provide an overview of the challenges faced by these approved drugs and to provide insights into the obstacles possibly holding back the successful commercialization of promising alkaloids. 


\subsubsection{Taxanes}

Paclitaxel is a highly hydrophobic chemotherapeutic drug that can cause embolism when injected intravenously without co-solubilizers due to the presence of particulate drug matters [172]. To enhance its water solubility and enable parenteral administration, paclitaxel is formulated in a 1:1 $(v / v)$ mixture of polyethoxylated castor oil (Cremophor EL) and dehydrated ethanol as the vehicle [173]. The amount of Cremophor EL administered is about $25 \mathrm{~mL}$ at the recommended dose of $175 \mathrm{mg} / \mathrm{m}^{2}$ once every three weeks, which necessitates a long infusion duration [174]. However, the use of Cremophor EL as solubilizing agents is clinically associated with several severe side effects, including anaphylaxis and life-threatening hypersensitivity reactions even with corticosteroid and antihistamines premedication $[175,176]$. Approximately $30 \%$ of patients receiving paclitaxel without premedication have been reported to experience these hypersensitivity reactions [18]. Cremophor EL has also been reported to cause nephrotoxicity and neurotoxicity [177]. Furthermore, studies have also shown that Cremophor EL adversely affects the efficacy of paclitaxel due to its ability to form plasma micelles capable of entrapping paclitaxel [178]. This leads to a reduced volume of distribution, increased systemic drug exposure and reduced drug clearance, resulting in the non-linear pharmacokinetics of paclitaxel observed clinically $[177,179]$. The fraction of drug trapped in micellar bodies is made unavailable to tumor sites despite increasing the dose, as higher doses introduce a higher concentration of Cremophor EL, further limiting the bioavailability and anti-tumor activity [177]. The non-linear pharmacokinetics, unpredictable activity and toxicity profile of paclitaxel further complicate combination chemotherapy regimens.

Similar to paclitaxel, the second generation taxane docetaxel is a hydrophobic drug with low aqueous solubility. To improve its solubility and enable intravenous administration, docetaxel is formulated with non-ionic surfactant polysorbate 80 (Tween 80) and ethanol, where the former is associated with hypersensitivity reactions [180]. Approximately $30 \%$ of patients receiving docetaxel without premedication have been reported to experience these hypersensitivity reactions, and $2 \%$ of patients experience severe reactions with premedication [18]. Although docetaxel possesses linear pharmacokinetics, there is large interindividual pharmacokinetics variability, particularly clearance and area under the curve (AUC), which causes highly unpredictable efficacy and toxicity profiles [181]. The most prominent toxicity of docetaxel is its hematological toxicities such as neutropenia, which correlates with the systemic exposure to unbound drugs [182]. All these aforementioned limitations prompted unceasing investigational efforts to develop novel nanoformulations for taxanes and obviate the need for surfactants including Cremophor EL and polysorbate 80 .

\subsubsection{Vinca Alkaloids}

As vinca alkaloids target cancer cells exclusively during metaphase, it is ideal to increase the drug concentration at the tumor site for a prolonged duration to kill actively dividing cancer cells during the most sensitive part of their cell cycle [183]. However, this could not be achieved due to their rapid plasma clearance and dose-limiting side effects such as sensory and motor peripheral neuropathies, which are the most common and severe in vincristine treatment $[184,185]$. As a result, the approved adult dose of vincristine is $1.4 \mathrm{mg} / \mathrm{m}^{2}$ and routinely capped at $2 \mathrm{mg}$ to prevent severe peripheral neuropathy, resulting in underdosing in patients with a body surface area larger than $1.43 \mathrm{~m}^{2}$ [16]. This suboptimal dosing is significant, as a study found that the average body surface area of 3613 adult cancer patients was $1.79 \mathrm{~m}^{2}$, with $1.91 \mathrm{~m}^{2}$ for men and $1.71 \mathrm{~m}^{2}$ for women [186]. This indicates that nearly all adult patients receiving vincristine are greatly underdosed, leading to unsatisfactory treatment outcomes. To overcome these pharmacokinetics and dosing limitations, liposomal vincristine (Marqibo) was developed and received accelerated FDA approval in 2012 for the treatment of Philadelphia chromosome (Ph)-negative acute lymphoblastic leukemia at the dose of $2.25 \mathrm{mg} / \mathrm{m}^{2}$ without dose capping [187,188]. As compared to free vincristine, Marqibo has prolonged plasma circulation, lower clearance 
and higher AUC without apparent toxicity exacerbation at doses unachievable by free vincristine [187,189-191].

\subsubsection{Topoisomerase I Inhibitors}

Irinotecan has a complex metabolism due to the involvement of various drug-metabolizing enzymes, such as cytochrome P450 (CYP) and uridine diphosphate glucuronosyltransferase 1A (UGT1A), and thus is subjected to large interindividual pharmacokinetic variabilities. Following administration, irinotecan is metabolized by carboxylesterases to its active metabolite, SN-38, which is approximately 100- to 1000-fold more potent than the parent drug. SN-38 is then immediately inactivated within minutes via glucuronidation by UGT1A1 to the inactive SN-38 glucuronide (SN-38G) and excreted via the bile, resulting in the short half-life of irinotecan [192]. The use of irinotecan is often limited by dose-limiting toxicities, such as diarrhea and neutropenia, which shows significant interindividual variability even at standard doses due to genetic variations in drug-metabolizing enzymes and drug transporters [17]. Compounding these limitations is the fact that enterohepatic recirculation of SN-38G exposes SN-38G to bacterial enzymes in the intestines which convert SN-38G to active SN-38, resulting in serious and life-threatening late diarrhea among patients receiving irinotecan [171]. The strategy of UGT1A1 genotype-guided irinotecan dosing has been recently investigated in a phase III trial which reported a significant increased pathological complete response (pCR) rate when combined with capecitabinebased neoadjuvant chemoradiotherapy in patients with locally advanced rectal cancer [193]. To overcome the limitations of irinotecan, several approaches have been investigated. The most successful example is the nanomedicine liposomal irinotecan (Onivyde) which was approved by the FDA in 2015 for the treatment of metastatic pancreatic cancer in combination with 5-fluorouracil and folinic acid. Nanoliposomal irinotecan encapsulates and prevents irinotecan from being converted into SN-38 in the circulation to increase and sustain the intra-tumoral levels of both irinotecan and SN-38 [194,195].

\section{Lipid-Based Nanoparticles for Encapsulation of Anticancer Alkaloids}

Considering all the foregoing hints, nanocarriers could be a potential strategy to overcome the limitations of alkaloids. Nanocarriers are around 5 to $200 \mathrm{~nm}$ in size and can be used in a wide range of applications [196]. They can be categorized into various types (e.g., organic, inorganic, polymeric, biological, lipid-based nanocarriers) according to their physical properties, chemical properties, morphology and size. Among the carriers, lipid-based nanocarriers offer an alternative to solubilize, encapsulate and deliver alkaloids in a programmed manner to enhance their water solubility, bioavailability and anticancer efficacy [25]. Examples of lipid-based nanocarriers are liposomes, solid lipid nanoparticles (SLN) and nanostructured lipid-carriers (NLC) (Figure 2). These drug carriers are made up of biocompatible lipids triglycerides, cholesterol and phospholipids in which most of them are derivatized based on or extracted from natural sources, resulting in their excellent biodegradability and biocompatibility [197]. Excipients use in lipid carriers such as cholesterol, PEG and phosphatidylcholine have established toxicology data and safety profiles for their use in pharmaceutical products, further strengthening their potential as the ideal drug delivery system [198]. Lipid-based nanoparticles with an average size of $100 \mathrm{~nm}$ and have longer circulation half-lives which enhance their propensity to extravasate through vascular fenestrations of tumors' vasculature, thus enhancing the potency of anticancer agents [199]. However, it is relatively difficult to prepare such small-sized lipidbased nanoparticles. In this regard, a "top down" size reduction approach that requires high energy input (e.g., sonication) and a "bottom up" method that produces nanoparticles by lipid condensation from solution can be used to solve this problem [200]. As far as we know, clinically approved cancer nanomedicines that utilize lipid-based nanocarriers as drug delivery agents have particle sizes larger than $80 \mathrm{~nm}$, for example, Doxil80-100 nm), Marqibo (100 nm) and Abraxane (130 nm) [190,201,202]. Numerous studies have been conducted to encapsulate alkaloids into lipid nanocarriers. 


\section{Lipid-based Drug Delivery System}
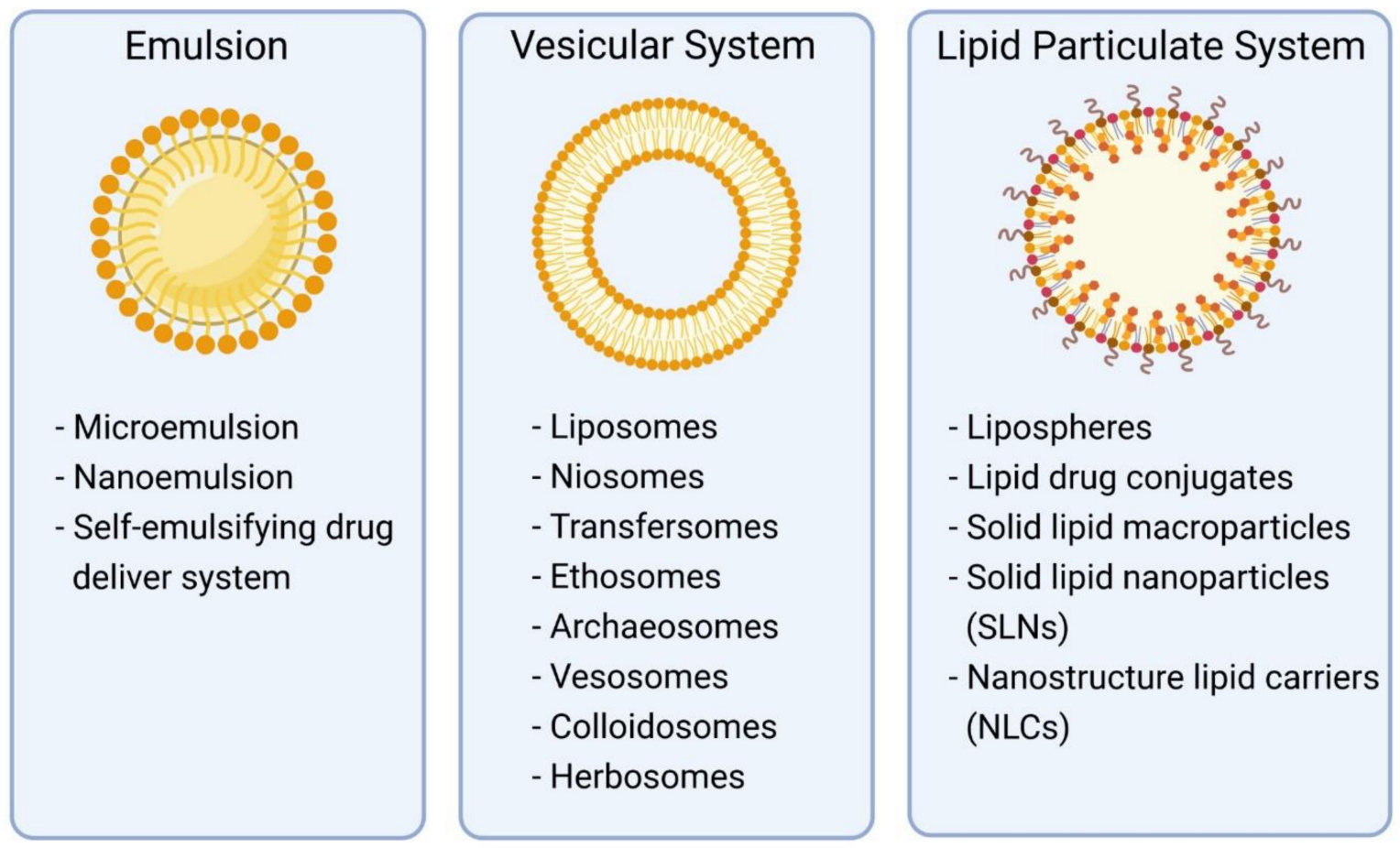

Figure 2. Classification of Lipid-based Nanocarriers.

\subsection{Liposome}

Liposomes are one of the extensively studied lipid vesicles, which are made up of phospholipids and an aqueous medium. Lipid vesicles are formed when lipids interact with the aqueous medium, where the lipid hydrophilic head group envelops the aqueous core along with exposure of the hydrophilic tail group to the external medium. Owing to this distinct structural property, drugs can be entrapped in the lipid bilayer or loaded in the internal aqueous core of liposomes depending on their hydrophilicity, for example, Doxil and Onivyde [203]. The first nano-based formulations approved by the FDA for cancer treatment are liposomal anticancer drugs. Doxil was the first doxorubicin-loaded liposomal drug which received FDA approval in 1995 to be used in the treatment of AIDS-related multiple myeloma and Kaposi sarcoma due to its lower cardiotoxicity and higher efficacy as compared to free doxorubicin alone. The clinical success of Doxil further established the potential of liposomes in drug delivery, and many promising liposomal formulations are currently being scrutinized intensively in clinical studies [203,204]. Reduced doselimiting toxicities, improved undesirable pharmacokinetics and drug solubility are the primary objectives in liposomal development to deliver alkaloids. Liposomes' stability is one of the major issues in the development of liposomal alkaloids [197]. The drug to lipid ratio and lipid composition have to be taken into consideration in preparing physically stable liposomal alkaloids. Neutral zwitterionic lipids are the most commonly used lipids in preparing liposomes such as phosphatidylcholine. Phospholipids and cholesterol can be added to enhance stability, reduce aggregation and improve permeability of drugs [205,206]. Introduction of the PEGylation approach in the early nineties was shown to prolong the circulation time of liposome significantly due to steric stabilization of vesicles [207]. Likewise, incorporation of PEG-modified lipids was found to enhance delivery and cytotoxicity of paclitaxel liposome to human cancer cells [208]. However, 
PEG, which is hydrophobic in nature, was later found to lower the polarity of the aqueous matrix and destabilize the liposomes, leading to rapid drug leakage. To overcome the issue, poly(zwitterionic) polymers such as poly[2-(methacryloyloxy)ethyl phosphorylcholine) (PMPC) [209] and poly(carboxybetaine) (PCB) [210] were introduced to replace PEG. That said, liposomes have disadvantages including limited drug loading capacity due to space available in liposomal lipid membranes, inadequate control of drug release, reproducibility issues and stability issues [211]. The drug-loading capacity of liposome can be solved by a remote loading approach where the drug will be added to preformed liposomes via $\mathrm{pH}$ gradient or ion gradient competent to create a $\mathrm{pH}$ gradient [212].

In 2014, liposomes were used to co-encapsulate doxorubicin and a contrast agent (Magnevist) or hyperthermic agent $\left(\mathrm{Fe}_{3} \mathrm{O}_{4}\right)$ [213,214]. Doxorubicin has also been encapsulated into ultrasound-sensitive liposomes in which the drug release can be facilitated by sonication that degrades liposomes, co-encapsulated with curcumin in liposomes to enhance anti-tumor efficacy of doxorubicin in the C26 colon cancer cell line, encapsulated in arginine-penetrating peptides/PEG modified liposomes to decrease in vitro cytotoxicity and enhance delivery of doxorubicin for the treatment of ovarian cancer [215-217]. In addition, incorporation of docetaxel in anacardic acid and PEG-modified liposomes have proven to stabilize docetaxel [218]. Many different liposomes and modified liposomes were designed to carry a variety of anticancer agents, such as paclitaxel and 5-fluorouracil [219].

Liposomal preparation requires a cryogenic atmosphere brought on to the introduction of vesicular drug delivery systems using non-ionic surfactants. It was named niosome consisting of either uni- or multi- lamellar vesicles. Niosome was first introduced in the cosmetic industry and its potential application in drug delivery was only discovered thenceforth [220]. The unique structure of niosome allows it to encapsulate both hydrophilic materials in vesicular aqueous core and lipophilic materials in the bilayer domain. It is composed of non-ionic surfactants with cholesterol and can increase the size and provide charge to vesicles, therefore, enhancing the entrapment efficiency of noisome. Niosome has a similar structure as liposomes and it is expected to be a better delivery system than liposomes due to its stability, cost and entrapment efficiency [221,222]. Nevertheless, only few niosome formulations are tested in clinical trials, and no formulations are commercially marketed heretofore owing to their low efficacy [223]. Ethosome is also a modified version of classical liposomes and is mainly composed of phospholipids, ethanol and water in which the concentration of ethanol is relatively high, differentiating it from other vesicular carriers. High ethanol constituents of ethosome improve skin permeability by releasing the encapsulated materials into deeper layers and systemic circulation [224,225]. For transdermal delivery of drugs, ethosome is superior over classical liposomes due to its higher entrapment efficiency, more negative zeta potential and smaller size $[226,227]$. Despite having these superiorities, only few ethosome formulations enter clinical trials due to limitations such as low yield and suitability to carry potent drugs only but not drugs which require a high concentration of blood [224].

\subsection{Micelles}

Micelles are colloidal systems formed through self-assembly of amphiphilic molecules. They can be further classified into polymeric micelles, lipid micelles and lipid polymeric hybrid micelles based on types of amphiphilic molecules. Amphiphilic molecules in lipid micelles are normally small-molecule surfactants. Unlike liposomes having a lipid bilayer, lipid micelles have a monolayer with an outer hydrophilic corona enclosing an inner hydrophobic core form by hydrophobic acyl chains [228]. Critical micelle concentration $(\mathrm{CMC})$ refers to concentration of surfactants above which micelles form. It is an important surfactants parameter to consider in designing micelles [197]. Enhancing solubility of drugs is the primary objective of designing micelles as drug nano-carriers. Hydrophobic drugs such as docetaxel and paclitaxel are carried in the lipophilic core of micelles [228]. Nevertheless, lipid micelles possess major limitations: unstable in bloodstream as dissociation occurred upon dilution below the micelle forming concentration (CMC) and 
limited interior hydrophobic space influencing the loading capacity of drugs. In order to stabilize the micelles by reinforcing weak intermolecular interactions, several strategies such as the formation of covalent crosslinking (for i.e., shell crosslinking) and non-covalent crosslinking (for i.e., diblock copolymers) can be used [229]. Lipid micelle has been used to deliver various drugs including paclitaxel, doxorubicin and camptothecin in the preclinical stage [230-232]. Cabral and co-workers identified that small polymeric micelles are suitable in delivering drug to the tumor site due to their favorable size range between 30 to $100 \mathrm{~nm}$ which penetrates well in highly permeable tumors [200]. However, they are not up to the market until today due to insufficient cellular interaction with tumor cells for cellular uptake and poor physical stability in vivo [233]. Even though both micelles and vesicles were formulated in the same principle whereby the lipid molecules reorganized and clustered together in an aqueous solution, the lipid layers were formed differently depending on their shapes. Lipid micelles were formed by wedge-shaped lipid molecules with the hydrophobic tails facing inwards, whereas the vesicles were formed by the cylinder-shaped phospholipid molecules with the hydrophobic tails sandwiched between the hydrophilic head groups [234].

\subsection{Solid Lipid Nanoparticles}

Comparing the lipid-based nanocarriers discussed, solid lipid nanoparticles (SLN) represent a colloidal drug delivery system with an external aqueous phase and internal lipid phase introduced in the early 1990s. They are composed of a combination of various solid lipids such as waxes and fatty acids, as well as mono-, di- and triacylglycerols that form a lipid matrix entrapping drugs or other hydrophobic materials. Beneficial properties of SLN, such as cost effectiveness, non-toxicity, ease of preparation, controlled drug release, good system stability and provision of target-specific effects, made them outstrip other carriers when they were first introduced $[235,236]$. On top of that, use of IV acceptable solid lipids (e.g., phospholipids, glycerides) and surfactants (e.g., poloxamer 188, lecithin, tween-80) makes SLN a versatile platform for drug delivery readily to translate into clinical application [235]. SLN-based formulations have shown a substantial enhancement in the anti-tumor efficacy of hydrophobic drugs. For example, resveratrol-SLN have greater inhibitory effects against the proliferation, invasion and migration of breast cancer cells than the free drug alone; talazoparib-SLN improve the therapeutic index against triplenegative breast cancer by overcoming homologous recombination-mediated resistance and talazoparib toxicity [237]. However, the highly organized crystalline structure of solid lipids leaves a limited room for drug incorporation which contributes to low drug capacity and drug expulsion during storage [238]. However, the highly organized crystalline structure of solid lipids leaves a limited room for drug incorporation which contributes to a low drug-loading capacity and drug expulsion during storage [238]. To overcome this problem, Muller and colleagues have come out with a novel lipid delivery system called nanostructured lipid carriers (NLC) [239].

\subsection{Nanostructured Lipid Carriers}

NLC are a modified version of conventional SLN by incorporating liquid lipids with a solid lipid. The room between crystal imperfections and fatty acid chains of NLC allows more drug accommodation. Moreover, certain drugs are more soluble in liquid lipids than solid lipids [240]. Hence, NLC as the second generation lipid carriers after SLN reduce drug expulsion during storage and enhance the drug-loading capacity [238]. NLC can be prepared using various surfactants and co-surfactants, allowing them to be formulated for various administration routes (e.g., parenteral, oral, topical, ocular, nasal) to deliver drugs and active substances for biochemical, cosmetic and pharmaceutical purposes [240]. NLC possess favorable properties of low toxicity and controlled drug release, and provide target-specific effects and a high drug load for both hydrophilic and hydrophobic agents, making them outstrip SLN when they were introduced $[235,241]$. NLC-based formulations have been studied extensively for the delivery of anti-tumor 
agents. For example, 6-gingerol-NLC has a greater water solubility and oral bioavailability than the free drug alone, penetrating peptides, and hyaluronic-acid-modified artesunateNLC has a better cell-membrane-penetrating ability against hepatic cancer; thymoquinoneNLC and fluvastatin-NLC have an improved anti-tumor efficacy against hepatic cancer and prostate cancer, respectively [242].

Lipid-based delivery systems attracted a great deal of attention in the past decades as a strategy to enhance anticancer efficacy and overcome delivery barriers and the therapeutic index of various drugs, especially alkaloids. Myriads of preclinical studies have been focused on the use of lipid carriers to deliver alkaloids due to their potential in cancer treatment. Table 2 summarizes alkaloids that have been encapsulated in lipid-based nanocarriers for cancer treatment. Some of them utilized vesicular systems while others used lipid-particulate systems.

Table 2. Alkaloids that have been Successfully Encapsulated in Lipid-based Nanoparticles.

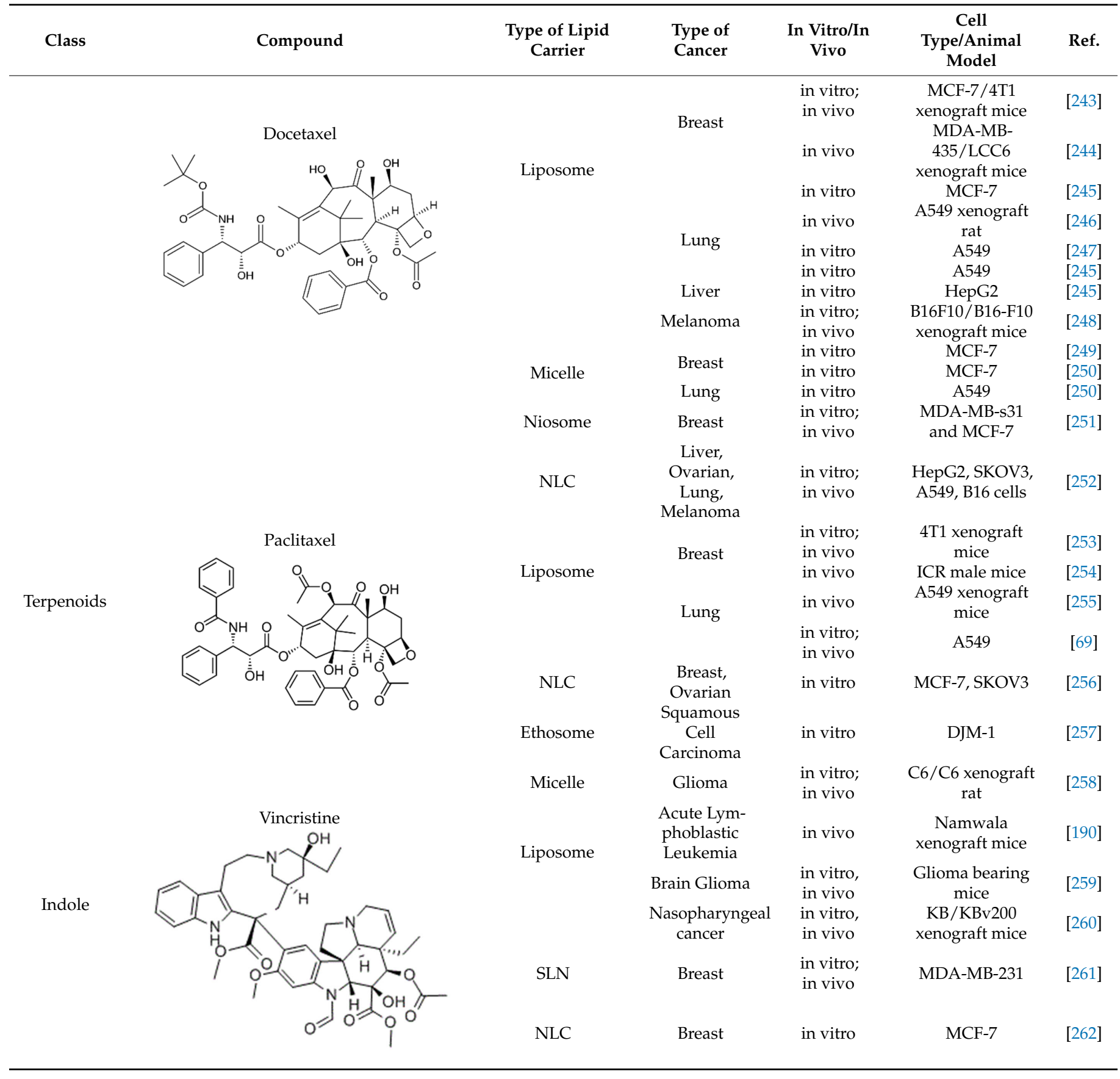


Table 2. Cont

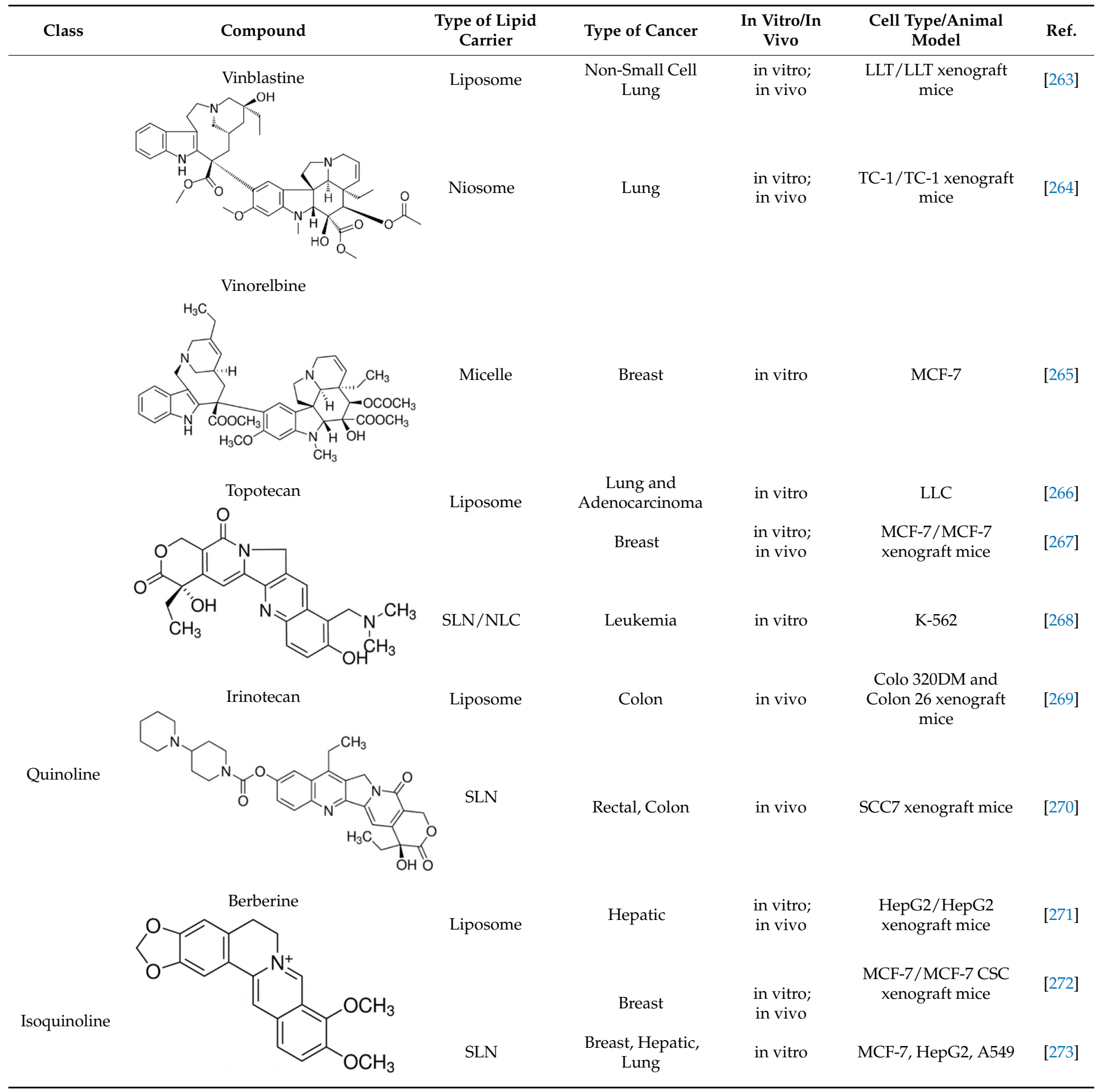

5. Integration of Lipid-Based Nanoparticles Improves Efficacy and Safety of Alkaloids 5.1. In Vitro Efficacy of Alkaloid Encapsulated in Lipid-Based Nanoparticles

The encapsulation of alkaloids in lipid-based nanoparticles have been extensively studied in numerous cancers, such as breast, lung and hepatocellular carcinoma [205]. Table 3 summarizes the in vitro efficacy of encapsulated alkaloids. The encapsulation of alkaloidal drugs in lipid-based nanoparticles generally improves cytotoxicity reflected by a reduction in the $\mathrm{IC}_{50}$. Considerable reductions in the $\mathrm{IC}_{50}$ were observed in cells treated with encapsulated alkaloids, most notably lipid-based docetaxel, paclitaxel and vincristine as compared to their respective free drugs. The higher anti-cancer effects could be attributed to a possible increase in cellular uptake by modulating active and passive 
transport to overcome the biological barriers and drug resistance. In addition, differences in the cellular uptake mechanism between the diffusion of free alkaloids and endocytosis of encapsulated alkaloids could be one of the potential contributing factors [274-276]. Apart from that, improvements in efficacy were observed in the encapsulated alkaloids ranging from 20.24 to $99.94 \%$ as compared to free drugs. Free topotecan exhibited a IC 50 of 1.88 $\mu \mathrm{g} / \mathrm{mL}$ in BT20 breast cancer cells, and the $\mathrm{IC}_{50}$ of topotecan-encapsulated liposomes was significantly reduced to $0.33 \mu \mathrm{g} / \mathrm{mL}$, showing an approximate six-fold reduction compared to the free form of topotecan [266]. Free docetaxel exhibited the $\mathrm{IC}_{50}$ of $14.4 \mu \mathrm{g} / \mathrm{mL}$ in MCF7 cells, whereas liposomal docetaxel exhibited an eight-fold reduced $\mathrm{IC}_{50}$ of $1.9 \mu \mathrm{g} / \mathrm{mL}$ with approximately an eight-fold reduction from its free form [243]. Similarly, the $\mathrm{IC}_{50}$ of free vincristine and liposomal vincristine in $\mathrm{KB}$ cells was $3.47 \mu \mathrm{g} / \mathrm{mL}$ and $0.0021 \mu \mathrm{g} / \mathrm{mL}$, respectively [260]. In general, alkaloids encapsulated in lipid-based nanoparticles exhibit elevated cytotoxicity at a lower concentration as compared to their respective free drugs. This may be attributed to a smaller nanoparticle size that enhances the drug uptake [26].

Table 3. In vitro Efficacy of Alkaloids in Lipid-based Nanoparticles.

\begin{tabular}{|c|c|c|c|c|c|c|c|c|}
\hline \multirow[b]{2}{*}{$\begin{array}{l}\text { Type of Lipid } \\
\text { Carrier }\end{array}$} & \multirow[b]{2}{*}{ Alkaloids } & \multirow[b]{2}{*}{$\begin{array}{l}\text { Type of } \\
\text { Cancer }\end{array}$} & \multirow[b]{2}{*}{ Cell Line } & \multicolumn{4}{|c|}{$\mathrm{IC}_{50}$} & \multirow[b]{2}{*}{ Ref. } \\
\hline & & & & $\begin{array}{l}\text { Exposure } \\
\text { Time (h) }\end{array}$ & $\begin{array}{c}\text { Free Drug } \\
(\mu \mathrm{g} / \mathrm{mL})\end{array}$ & $\begin{array}{c}\text { Drug-Carrier } \\
(\mu \mathrm{g} / \mathrm{mL})\end{array}$ & $\begin{array}{l}\text { Reduction } \\
\text { in } \mathrm{IC}_{50}(\%)\end{array}$ & \\
\hline \multirow{15}{*}{ Liposome } & \multirow{2}{*}{ Vincristine } & $\begin{array}{c}\text { Oral } \\
\text { Epidermoid }\end{array}$ & KB & 72 & 3.47 & 0.0021 & 99.94 & \multirow[b]{2}{*}{ [260] } \\
\hline & & $\begin{array}{l}\text { MDR Oral } \\
\text { Epidermoid }\end{array}$ & KBv200 & 72 & 1.31 & 0.33 & 74.88 & \\
\hline & \multirow{4}{*}{ Topotecan } & Breast & BT20 & 24 & 1.88 & 0.33 & 82.45 & [266] \\
\hline & & MDR Breast & $\begin{array}{l}\text { MCF- } \\
7 / \text { ADR }\end{array}$ & 48 & 2.47 & 0.71 & 71.43 & [267] \\
\hline & & $\begin{array}{l}\text { Non-Small } \\
\text { Cell Lung }\end{array}$ & LLC & 24 & 2.49 & 0.78 & 68.67 & [266] \\
\hline & & Breast & MCF-7 & 48 & 2.07 & 2.07 & -0.22 & [267] \\
\hline & \multirow{7}{*}{ Docetaxel } & Breast & MCF-7 & 72 & 14.40 & 1.90 & 86.81 & [243] \\
\hline & & $\begin{array}{l}\text { Non-Small } \\
\text { Cell Lung }\end{array}$ & A549 & 24 & 9.39 & 2.42 & 74.23 & [245] \\
\hline & & Hepatocellular & HepG2 & 24 & 7.91 & 3.12 & 60.56 & [245] \\
\hline & & Breast & MCF-7 & 24 & 8.40 & 3.77 & 55.12 & [245] \\
\hline & & Melanoma & B16F10 & 48 & 12.46 & 6.60 & 47.03 & [248] \\
\hline & & Breast & $4 \mathrm{TI}$ & 72 & 13.00 & 8.70 & 33.08 & [243] \\
\hline & & Breast & TUBO & 72 & 4.70 & 4.10 & 12.77 & [243] \\
\hline & Berberine & Hepatocellular & HepG2 & 72 & 4.23 & 1.67 & 60.52 & [271] \\
\hline & Paclitaxel & $\begin{array}{l}\text { Non-Small } \\
\text { Cell Lung }\end{array}$ & A549 & 72 & 35.42 & 28.25 & 20.24 & [69] \\
\hline \multirow{6}{*}{ NLC } & & Breast & MCF-7 & 24 & 0.011 & 0.0031 & 71.97 & [262] \\
\hline & Vincristine & $\begin{array}{c}\text { Diffuse large } \\
\text { B-cell } \\
\text { lymphoma }\end{array}$ & LY1 & 48 & 9.82 & 3.31 & 66.29 & [277] \\
\hline & \multirow{4}{*}{ Docetaxel } & $\begin{array}{l}\text { Non-Small } \\
\text { Cell Lung }\end{array}$ & A549 & 96 & 0.60 & 0.12 & 79.73 & \multirow{4}{*}[252]{} \\
\hline & & Ovarian & SKOV3 & 96 & 0.065 & 0.016 & 75.00 & \\
\hline & & Hepatocellular & HepG2 & 96 & 0.78 & 0.38 & 51.04 & \\
\hline & & $\begin{array}{l}\text { Murine } \\
\text { melanoma }\end{array}$ & B16 & 96 & 0.58 & 0.36 & 38.89 & \\
\hline
\end{tabular}


Table 3. Cont.

\begin{tabular}{|c|c|c|c|c|c|c|c|c|}
\hline \multirow[b]{2}{*}{$\begin{array}{l}\text { Type of Lipid } \\
\text { Carrier }\end{array}$} & \multirow[b]{2}{*}{ Alkaloids } & \multirow[b]{2}{*}{$\begin{array}{l}\text { Type of } \\
\text { Cancer }\end{array}$} & \multirow[b]{2}{*}{ Cell Line } & \multicolumn{4}{|c|}{$\mathrm{IC}_{50}$} & \multirow[b]{2}{*}{ Ref. } \\
\hline & & & & $\begin{array}{l}\text { Exposure } \\
\text { Time (h) }\end{array}$ & $\begin{array}{c}\text { Free Drug } \\
(\mu \mathrm{g} / \mathrm{mL})\end{array}$ & $\begin{array}{c}\text { Drug-Carrier } \\
(\mu \mathrm{g} / \mathrm{mL})\end{array}$ & $\begin{array}{l}\text { Reduction } \\
\text { in } \mathrm{IC}_{50}(\%)\end{array}$ & \\
\hline & \multirow{4}{*}{ Paclitaxel } & MDR Breast & $\begin{array}{l}\text { MCF- } \\
7 / \mathrm{ADR}\end{array}$ & 48 & 8.61 & 0.065 & 99.25 & \multirow{4}{*}{ [256] } \\
\hline & & $\begin{array}{c}\text { MDR } \\
\text { Ovarian }\end{array}$ & $\begin{array}{l}\text { SKOV3- } \\
\text { TR30 }\end{array}$ & 48 & 9.35 & 0.10 & 98.93 & \\
\hline & & Breast & MCF-7 & 48 & 0.29 & 0.075 & 74.14 & \\
\hline & & Ovarian & SKOV3 & 48 & 0.16 & 0.053 & 66.88 & \\
\hline \multirow{4}{*}{ SLN } & \multirow{3}{*}{ Berberine } & $\begin{array}{l}\text { Non-Small } \\
\text { Cell Lung }\end{array}$ & A549 & 24 & 13.45 & 5.11 & 62.00 & \multirow{3}{*}{ [273] } \\
\hline & & Hepatocellular & HepG2 & 24 & 3.46 & 1.61 & 53.40 & \\
\hline & & Breast & MCF-7 & 24 & 13.45 & 6.90 & 48.75 & \\
\hline & Vincristine & Breast & $\begin{array}{c}\text { MDA-MB- } \\
231\end{array}$ & 72 & 0.09 & 0.078 & 11.05 & [261] \\
\hline \multirow{5}{*}{ Micelle } & \multirow{3}{*}{ Docetaxel } & Breast & MCF-7 & 72 & 9.00 & 0.090 & 99.00 & \multirow{2}{*}{ [250] } \\
\hline & & $\begin{array}{l}\text { Non-Small } \\
\text { Cell Lung }\end{array}$ & A549 & 72 & 12.80 & 0.56 & 95.63 & \\
\hline & & Breast & MCF-7 & 48 & 1.28 & 0.25 & 80.39 & [249] \\
\hline & Vinorelbine & Breast & MCF-7 & 72 & 8.13 & 1.20 & 85.24 & [265] \\
\hline & Paclitaxel & Glioma & C6 & 48 & 0.36 & 0.24 & 32.92 & [258] \\
\hline \multirow{3}{*}{ Niosome } & \multirow{2}{*}{ Docetaxel } & \multirow{2}{*}{ Breast } & $\begin{array}{c}\text { MDA-MB- } \\
231\end{array}$ & 24 & 12.34 & 5.47 & 55.67 & \multirow{2}{*}{ [251] } \\
\hline & & & MCF-7 & 24 & 0.72 & 0.51 & 28.95 & \\
\hline & Vinblastine & Lung & TC-1 & 72 & 7.40 & 13.30 & -79.73 & [264] \\
\hline
\end{tabular}

Over decades, multidrug resistance (MDR) has been a major complex issue especially in cancer treatment. It can be either intrinsic or acquired due to prolonged drug exposure, resulting in drug efflux from the cancer cells, leading to a reduced intracellular drug concentration and diminished therapeutic efficacy. Increasing the dose of chemotherapeutic agents or using combination therapy are usually the courses of action at this point. However, it might lead to increased patient morbidity as a result of increased toxicity, eventually leading to treatment failure. Moreover, the approach of using combination therapy may be ineffective in preventing the development of drug resistance, as tumors are made of diverse populations of cells. These cells are genetically unstable and will inevitably develop resistance to multiple drugs of the combination therapy $[19,278,279]$. In fact, the majority of cancer patients died from a disseminated disease that developed resistance to multiple treatment modalities [280]. MDR normally arises from the overexpression of ATP-binding cassette $(\mathrm{ABC})$ transporters, especially ABCB1 (also known as P-glycoprotein or MDR1), ABCG2 (also known as breast cancer resistance protein BCRP) and ABCC1 (also known as multidrug-resistant protein-1 MRP-1) [281]. These ABC transporters have been demonstrated to efflux numerous chemotherapeutic agents, including taxanes, vinca alkaloids, topotecan and irinotecan [280]. Therefore, extensive efforts were undertaken to search for effective treatments to overcome MDR.

Lipid-based nanoparticle encapsulation of chemotherapeutic agents serves as a potential strategy in overcoming MDR. For examples, Yu and co-workers formulated topotecan liposome, and Zhang and co-workers developed paclitaxel-NLC, both tested in MCF-7 and drug-resistant MCF-7/ADR breast cancer cell lines [256,267]. A particularly promising trend was observed in the luminal breast cancer cell line where encapsulated alkaloids displayed a lower $\mathrm{IC}_{50}$ value in the resistant cell line compared to the non-resistant breast cancer cell line. In the case of topotecan-liposome, it exhibited a $\mathrm{IC}_{50}$ of $2.07 \mu \mathrm{g} / \mathrm{mL}$ in the MCF-7 cell line; however, the $\mathrm{IC}_{50}$ was reduced to $0.71 \mu \mathrm{g} / \mathrm{mL}$ in the MCF-7/ADR cell line, 
showing an approximate three-fold reduction, while for paclitaxel-NLC, it exhibited a $\mathrm{IC}_{50}$ of $0.075 \mu \mathrm{g} / \mathrm{mL}$ in the MCF-7 cell line, but the $\mathrm{IC}_{50}$ was reduced to $0.065 \mu \mathrm{g} / \mathrm{mL}$ in the MCF-7 / ADR cell line. On the other hand, a higher $\mathrm{IC}_{50}$ is observed in resistant cell lines; for example, vincristine-liposomes have a $\mathrm{IC}_{50}$ value of $0.0021 \mu \mathrm{g} / \mathrm{mL}$ in non-resistant (KB) and $0.33 \mu \mathrm{g} / \mathrm{mL}$ in resistant oral epidermoid (KBv200) cell lines, respectively, while the $\mathrm{IC}_{50}$ of paclitaxel-NLC on non-resistant (SKOV3) and resistant ovarian (SKOV3-TR30) cell lines are $0.053 \mu \mathrm{g} / \mathrm{mL}$ and $0.1 \mu \mathrm{g} / \mathrm{mL}$, respectively [254,256]. Nevertheless, they are still more effective towards oral epidermoid and ovarian cancers when compared to free drugs. This may be attributed to the small particle size of alkaloid-encapsulated lipid nanocarriers which are taken up by cells through endocytosis that may bypass or evade $\mathrm{ABC}$ transporters which are responsible to efflux cytotoxic agents after being released into the cytoplasm and the subsequent emergence of MDR in cancer treatment. On top of that, a smaller particle size may increase the intracellular concentration of the alkaloid which will enhance its cytotoxicity in resistant cells [280,282].

\subsection{In Vivo Efficacy and Toxicity of Alkaloids in Lipid-Based Nanoparticles}

The in vivo efficacy and toxicity of the lipid-based nanoparticles are summarized in Table 4. The encapsulation of alkaloid drugs in lipid-based nanocarriers generally improves their anti-tumor efficacies, with better tolerability as reflected by the changes in body weight. In the study by Zhigaltsev and co-workers, the liposomal docetaxel appeared to be less effective than Taxotere (commercial formulation of docetaxel) when administered at the same dose $(25 \mathrm{mg} / \mathrm{kg})$. However, they found that the liposomal encapsulation of docetaxel reduces the toxicity of docetaxel and allows a three-fold higher maximum tolerated dose (MTD) than Taxotere, from $29 \mathrm{mg} / \mathrm{kg}$ to $>88 \mathrm{mg} / \mathrm{kg}$. The increased MTD in liposomal docetaxel may be attributed to reduced systemic exposure to docetaxel and reduced vehicle toxicity due to the absence of surfactant polysorbate 80 [244]. The concept of MTD is fundamental in clinical oncology, where the optimal dose of chemotherapeutic agents is determined based on the safety aspects. The potential for tumor remission is maximized by administering the highest possible dose based on the ability of patients to tolerate the associated side effects [283]. Thus, the ability of lipid-based nanoparticles to increase the MTD of docetaxel by more than three-fold in vivo supports the broad application of nanoparticles in cancer treatment.

Consistent with their in vitro results reporting an enhanced ability to eliminate MDR breast cancer cell lines, Yu and colleagues demonstrated that liposomal topotecan possesses substantially enhanced anti-tumor efficacy in resistant MCF-7/ADR cell xenografts in mice as compared to free topotecan [267]. This is clinically significant, as the ability of nanoparticles to overcome the drug resistance mechanism allows effective use of established chemotherapeutic drugs. Indeed, lipid-based nanocarriers such as liposomes and micelles are the most studied in targeting MDR in cancer [285].

The administration of conventional chemotherapeutic drugs has generally been limited by serious side effects due to their lack of specificity to cancer cells, indiscriminate tissue distribution and toxic formulation excipients. Therefore, it is desirable to develop nanoformulations that possess the ability to target cancer cells passively or actively to minimize the collateral damage towards non-cancerous cells $[19,177,180]$. As shown in Table 4, considerable reductions in toxicity were observed in animals treated with lipid-based nanoparticles, most notably lipid-based docetaxel, paclitaxel and vincristine, as compared to their respective free drugs. Lipid encapsulation was shown to be able to improve the toxicity profile of the encapsulated drugs by approximately $30 \%$ in xenograft mouse models as compared to free drugs, while retaining or even demonstrating superior anti-tumor efficacy. This may be attributed to the EPR effects whereby nanoparticles preferentially extravasate and accumulate in tumor tissues due to the presence of inter-endothelial gaps in the tumor blood vessels formed during disorganized angiogenesis and defective lymphatic drainage $[78,80]$. 
Table 4. In vivo Efficacy and Toxicity of Alkaloids in Lipid-based Nanoparticles.

\begin{tabular}{|c|c|c|c|c|c|c|c|c|c|c|}
\hline \multirow{2}{*}{$\begin{array}{l}\text { Type of Lipid } \\
\text { Carrier }\end{array}$} & \multirow[b]{2}{*}{ Alkaloids } & \multirow{2}{*}{ Type of Cancer } & \multirow[b]{2}{*}{ Animal Model } & \multirow[b]{2}{*}{ Cancer Cell } & \multirow{2}{*}{$\begin{array}{c}\text { Route of } \\
\text { Administration }\end{array}$} & \multicolumn{2}{|c|}{$\begin{array}{c}\text { Reduction in Tumor } \\
\text { Volume (\%) }\end{array}$} & \multicolumn{2}{|c|}{ Weight Changes (\%) } & \multirow[b]{2}{*}{ Ref. } \\
\hline & & & & & & $\begin{array}{l}\text { Vs. Negative } \\
\text { Control }\end{array}$ & $\begin{array}{l}\text { Vs. Free } \\
\text { Drug }\end{array}$ & Free Drug & $\begin{array}{l}\text { Lipid- } \\
\text { Carrier }\end{array}$ & \\
\hline & \multirow[t]{2}{*}{ Irinotecan } & $\begin{array}{c}\text { Colorectal } \\
\text { Adenocarcinoma }\end{array}$ & Female ddY mice & Colo 320DM & IV & 97 & 92.5 & -18.1 & -5.2 & \multirow{2}{*}{269} \\
\hline & & Murine Colon & Female ddY mice & Colon 26 & IV & 36 & 14.7 & +7.8 & +3.9 & \\
\hline & \multirow{3}{*}{ Paclitaxel } & Breast & $\mathrm{BALB} / \mathrm{c}$ mice & $4 \mathrm{~T} 1$ & IV & 96.6 & 89.8 & +8.6 & +19 & [253] \\
\hline & & Non-Small Cell Lung & Male BALB/c mice & A549 & IV & 55.6 & 23.8 & +7.9 & +6.4 & [255] \\
\hline & & Breast & ICR male mice & - & IV & 38.2 & 10.5 & 0 & +30 & [254] \\
\hline & & \multirow{2}{*}{ Breast } & \multirow{2}{*}{ Female BALB/c mice } & TUBO & IV & 85.7 & 83.3 & +14 & +22 & \multirow{2}{*}{243} \\
\hline & & & & $4 \mathrm{~T} 1$ & IV & 78.9 & 71.4 & +18 & +36 & \\
\hline & & Non-Small Cell Lung & Sprague- Dawley rats & A549 & IV & 96.3 & 50 & -13 & +5.6 & [246] \\
\hline & Docetaxel & Breast & Female RAG2-M mice & $\begin{array}{l}\text { MDA-MB- } \\
\text { 435/LCC6 }\end{array}$ & IV & 34.8 & +25 & NR & NR & [183] \\
\hline & & Melanoma & C57BL/6 mice & B16-F10 & IV & 12 & 1.8 & -14.3 & +14.3 & [248] \\
\hline \multirow{5}{*}{ Liposome } & \multirow{2}{*}{ Topotecan } & Breast & $\begin{array}{l}\text { NCR nu/nu athymic } \\
\text { female mice }\end{array}$ & BT474 & IV & 83.3 & 63.6 & NR & NR & [284] \\
\hline & & MDR Breast & $\begin{array}{l}\text { Female BALB/c nude } \\
\text { mice }\end{array}$ & MCF-7/ADR & IV & 75.3 & 58.2 & NR & NR & [267] \\
\hline & Vinblastine & Non-Small Cell Lung & C57BL/6 mice & LLT & IV & 54.3 & 30.4 & NR & NR & [263] \\
\hline & Berberine & Breast & $\begin{array}{l}\text { Female BALB/c nude } \\
\text { mice }\end{array}$ & MCF-7 CSC & IV & 47.4 & 23.1 & NR & NR & [272] \\
\hline & Vincristine & MDR Oral Epidermoid & Male nude mice & KBv200 & IV & 44.3 & 2.9 & NR & NR & [260] \\
\hline \multirow[b]{2}{*}{ NLC } & Docetaxel & Murine melanoma & Female Kunming Mice & B16 & IV & 62 & 32 & +20 & +33.3 & [252] \\
\hline & Vincristine & $\begin{array}{l}\text { Diffuse Large B-Cell } \\
\text { Lymphoma }\end{array}$ & BALB/c mice & LY-1 & IV & 44.2 & 21.6 & -14.8 & +19.1 & {$[277]$} \\
\hline SLN & Irinotecan & Squamous Cell & $\begin{array}{l}\text { Female athymic nude } \\
\text { mice }\end{array}$ & SCC7 & Rectal & 70 & 58.3 & -6.9 & +0.8 & [270] \\
\hline \multirow{2}{*}{ Niosome } & Docetaxel & Breast & Female nude mice & MCF-7 & $\mathrm{PO}$ & 53.1 & 21.1 & +26.3 & +27 & [251] \\
\hline & Vinblastine & Murine Lung & Female C57BL/6 mice & TC-1 & IV & 33.3 & 18.5 & NR & NR & [264] \\
\hline
\end{tabular}


It is important to understand that the incorporation of compounds in nanocarriers significantly alters the properties of the compounds and changes the way they interact with biological systems [286-288]. However, a portion of the studies summarized in Table 4 did not report the basic toxicity profile, such as the weight changes induced by these lipid-based nanoparticles in animal models. Furthermore, many of these studies did not report the pharmacokinetic and biodistribution data. Previous studies have shown that administered nanoparticles are sequestered by macrophages of the mononuclear phagocyte system (MPS), causing high accumulation in the liver and spleen, resulting in local toxicity in these organs [289-291]. Furthermore, pharmacokinetic and biodistribution profiles of nanoparticles are important to predict their anti-tumor efficacy and toxicity profiles [287]. Thus, it is vital to include this information in addition to their anti-tumor efficacy in order to allow unbiased comparisons of lipid-based nanocarriers across experiments and achieve a balance of acceptable toxicity and good efficacy. Uncertainty regarding the hazard and safety information will impede the exploitation and use of these nanoparticles in humans. In fact, many nanomedicines failed in the clinical trials due to unexpected toxicities from preclinical studies, with the most recent example being MM-310 (liposomal docetaxel prodrug). MM-310 was discontinued in 2019 following reports of cumulative peripheral neuropathy in a Phase 1 clinical trial despite demonstrating excellent results in a preclinical study [292,293]. Therefore, it is ideal to standardize evaluation criteria and unify preclinical standards to accelerate clinical translation. Moreover, a number of studies compared their lipid-based nanoparticles with a solution of pure compounds, instead of formulations available on the market, such as Taxol (paclitaxel) or Taxotere (docetaxel). This may generate improper conclusions about the effectiveness and advantages of their nanoparticles as compared to the conventional medicines currently used clinically.

\subsection{From Bench to Bedside}

Similar to conventional drugs, the regulatory approval for nanomedicines is stringent, expensive and time-consuming, requiring evidence to prove their efficacy, safety and quality [294]. Furthermore, successful translation of nanomedicines from bench to bedside are often limited by design complexity which prevents economic production and scale-up production [20]. Nevertheless, a few anticancer alkaloids encapsulated in lipid-based nanoparticles have successfully overcome these hurdles and have been approved by the FDA and foreign equivalents. In this section, we aim to provide a snapshot of anticancer alkaloids encapsulated in lipid-based nanoparticles that have received regulatory approval and the current status of those undergoing different phases of clinical trials (Table 5).

Table 5. Clinically Approved Anticancer Alkaloids in Lipid-Based Nanoparticles and Clinical Trials to Date.

\begin{tabular}{|c|c|c|c|c|}
\hline Alkaloids & Product Name & $\begin{array}{c}\text { Type of } \\
\text { Lipid-Based } \\
\text { Nanoparticles }\end{array}$ & Indication & Status \\
\hline \multirow[b]{3}{*}{ Paclitaxel } & Lipusu & Liposome & $\begin{array}{c}\text { Squamous Non-small-cell } \\
\text { Lung Cancer }\end{array}$ & $\begin{array}{c}\text { Approved by State FDA of } \\
\text { China (2006); Phase IV } \\
\text { ongoing (NCT02996214) }\end{array}$ \\
\hline & LEP-ETU & Liposome & Metastatic breast cancer & $\begin{array}{l}\text { Phase II completed } \\
\text { (NCT01190982) }\end{array}$ \\
\hline & EndoTAG-1 & Cationic Liposome & $\begin{array}{l}\text { Locally advanced and/or } \\
\text { metastatic adenocarcinoma } \\
\text { of the pancreas }\end{array}$ & $\begin{array}{l}\text { Phase III ongoing } \\
\text { (NCT03126435) }\end{array}$ \\
\hline Docetaxel & $\begin{array}{c}\text { CPC634(CriPec } \\
\text { docetaxel) }\end{array}$ & Micelle & Ovarian cancer & $\begin{array}{l}\text { Phase II ongoing } \\
\text { (NCT03742713) }\end{array}$ \\
\hline
\end{tabular}


Table 5. Cont.

\begin{tabular}{|c|c|c|c|c|}
\hline Alkaloids & Product Name & $\begin{array}{c}\text { Type of } \\
\text { Lipid-Based } \\
\text { Nanoparticles }\end{array}$ & Indication & Status \\
\hline \multirow{4}{*}{ Irinotecan } & \multirow{2}{*}{ Onivyde } & \multirow{2}{*}{ Liposome } & Metastatic pancreatic cancer & Approved by FDA (2015) \\
\hline & & & Small cell lung cancer & $\begin{array}{l}\text { Phase III ongoing } \\
\text { (NCT03088813) }\end{array}$ \\
\hline & LY01610 & Liposome & Small cell lung cancer & $\begin{array}{l}\text { Phase II ongoing } \\
\text { (NCT04381910) }\end{array}$ \\
\hline & & & Advanced solid tumors & $\begin{array}{l}\text { Phase I ongoing } \\
\text { (NCT04088604) }\end{array}$ \\
\hline \multirow{3}{*}{ Topotecan } & FF-10850 & Liposome & Advanced solid tumors & $\begin{array}{l}\text { Phase I ongoing } \\
\text { (NCT04047251) }\end{array}$ \\
\hline & TLI & Liposome & Advanced solid tumors & $\begin{array}{l}\text { Phase I ongoing } \\
\text { (NCT00765973) }\end{array}$ \\
\hline & OSI-211 & Liposome & Small cell lung cancer & $\begin{array}{c}\text { Phase II completed } \\
\text { (NCT00046787) }\end{array}$ \\
\hline Lurtotecan & NX-211 & Liposome & $\begin{array}{l}\text { Metastatic or locally } \\
\text { recurrent head and neck } \\
\text { cancer }\end{array}$ & $\begin{array}{l}\text { Phase II completed } \\
\text { (NCT00022594) }\end{array}$ \\
\hline Vincristine & Marqibo (Onco TCS) & Liposome & $\begin{array}{c}\text { Acute lymphoblastic } \\
\text { leukemia }\end{array}$ & Approved by FDA (2012) \\
\hline Vinorelbine & TLC178 & Liposome & Advanced malignancies & $\begin{array}{l}\text { Phase I/II ongoing } \\
\text { (NCT02925000) }\end{array}$ \\
\hline
\end{tabular}

The first FDA-approved anticancer alkaloid that has been successfully encapsulated in lipid-based nanoparticles was liposomal vincristine (Marqibo), which was approved in 2012 for the treatment of Philadelphia chromosome-negative acute lymphoblastic leukemia $[45,190]$. In the phase I trial that led to its FDA approval, Marqibo was shown to overcome the dosing limitations of vincristine, allowing the administration of vincristine at the dose of $2.25 \mathrm{mg} / \mathrm{m}^{2}$ without dose capping and apparent toxicity exacerbation $[187,188]$. Furthermore, Marqibo has improved pharmacokinetic profiles, demonstrating prolonged plasma circulation, lower clearance and higher AUC than free vincristine [190,191]. A phase I study conducted in children showed that the approved adult weekly dose of $2.25 \mathrm{mg} / \mathrm{m}^{2}$ was well tolerated without evidence of neurotoxicity [189].

In 2015, the liposomal irinotecan (Onivyde) received its FDA approval for the treatment of metastatic pancreatic ductal adenocarcinoma (mPDAC) in combination with 5-fluorouracil and folinic acid in patients previously treated with gemcitabine-based treatment. The approval was based on the global phase III NAPOLI-1 trial which reported that the addition of Onivyde significantly improved the median overall survival (OS) compared with 5-fluorouracil + folinic acid alone (6.1 months vs. 4.2 months) (hazard ratio $0.67 ; p=0.012$ ) with a manageable safety profile in patients who progressed after gemcitabine-based therapy [195]. Subsequent extended follow-up analysis of the long-term survivors of the NAPOLI1 trial further confirmed the OS advantage of Onivyde + 5-fluorouracil + folinic acid as compared to 5 -fluorouracil + folinic acid alone (6.2 months vs. 4.2 months). Approximately $25 \%$ patients who received Onivyde +5 -fluorouracil + folinic acid were alive after a oneyear follow-up as compared to $13 \%$ patients who were given 5 -fluorouracil + folinic acid alone [295].

On the other hand, Lipusu was the first paclitaxel liposome approved for clinical use by the State Food and Drug Administration of China in 2006. It eliminates the use of the toxic vehicle Cremophor EL, thus reducing the toxicities while retaining the anti-tumor activity of free paclitaxel. A study reported that the hallmark hypersensitivity reactions 
of paclitaxel was not observed in 53 patients receiving Lipusu-based chemotherapy [296]. In addition, Lipusu has also shown comparable activity as a free paclitaxel but with a lower incidence of adverse effects in metastatic gastric cancer [297]. Randomized phase 4 trials (LIPUSU, NCT02996214) are currently on-going to study the safety and efficacy of the combination of Lipusu and cisplatin as the first-line treatment in patients diagnosed with advanced squamous NSCLC. Figure 3 summarizes the in-vitro, in vivo anti-tumor effects and the anticancer alkaloids encapsulated in lipid-based nanoparticles that have successfully received regulatory approval for clinical use.

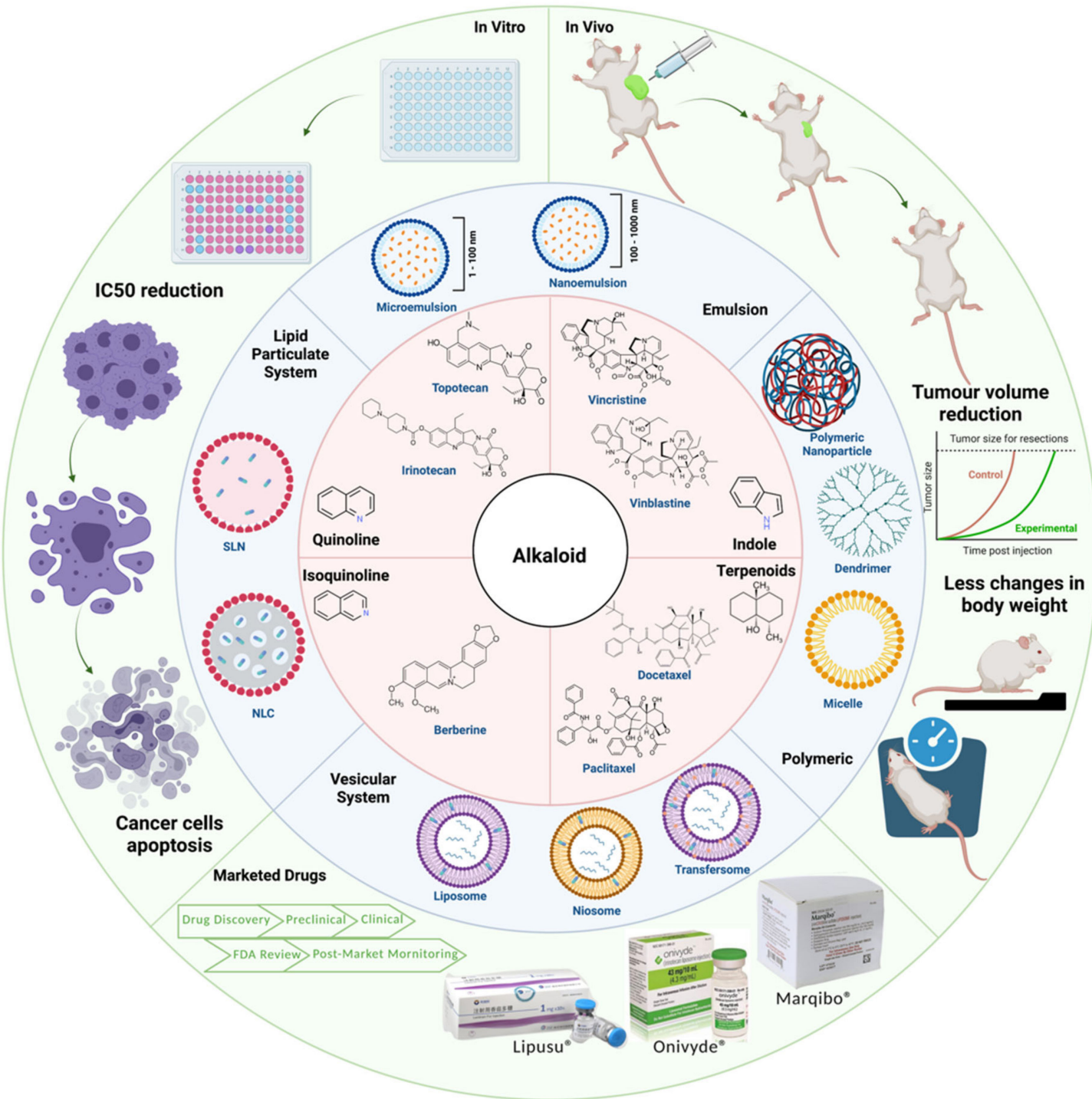

Figure 3. Overview highlighting the types of lipid-based nanoparticles that have been utilized to encapsulate anticancer alkaloids, the in vitro and in vivo anti-tumor effects and products that have successfully received regulatory approval for clinical use. As explored in this review, anticancer alkaloids encapsulated in lipid-based nanoparticles demonstrated enhanced in vitro efficacy (reduced $\mathrm{IC}_{50}$ ), in vivo efficacy (increased tumor volume reduction), in vivo toxicity profile (changes in body weight), as compared to unencapsulated anticancer alkaloids.

\section{Conclusions and Future Perspectives}

In the race against cancer, bioactive natural products such as alkaloids have gained great interest due to their vast scaffold diversity and structural complexity unrivaled by current synthetic drugs [8]. However, the anticancer alkaloids currently employed in clinical practice are largely limited by serious side effects due to their lack of specificity to cancer cells, indiscriminate tissue distribution and toxic formulation excipients. The last 
few decades have seen considerable progress in nanotechnology, offering a multitude of opportunities and possibilities to overcome these shortcomings. Apart from improving the bioavailability, the drug efficacy was largely improved by the controlled drug release of these nanocarriers [298]. Several stimuli such as temperature [299], $\mathrm{pH}$ [300] and redox sensitivity [301] were shown to trigger and enhance the release of the drug cargo in selected locations. Lipid-based nanoparticles, particularly liposomes, have been investigated and exploited in a vast range of pharmaceutical products owing to their unique, appealing characteristics for drug delivery. Lipid-based nanoparticles are envisioned to have a great impact on public health, especially with the recent success of the BioNTech/Pfizer (BNT162b2) and Moderna (mRNA-1273) COVID-19 mRNA vaccine [54,55].

Our review evaluated several lines of in vitro and in vivo evidence of the efficacy and toxicity of anticancer alkaloids encapsulated in lipid-based nanoparticles. Encapsulated alkaloids generally show enhanced in vitro cytotoxicity and an improved in vivo efficacy and toxicity profile than free alkaloids in various cancers. This may be attributed to the superiority in physicochemical properties and pharmacokinetic, pharmacodynamic and biodistribution profiles endowed by lipid-based nanoparticles. Studies also reported the ability of encapsulated alkaloids to overcome the long-dreaded MDR, which is the major cause of treatment failure and deaths among cancer patients [280]. Thus, lipidbased nanoparticles encapsulation proved to be a powerful approach for advancing the clinical translation of anticancer alkaloids. Three liposomal nanoformulations of alkaloids, Onivyde, Marqibo and Lipusu, have been approved for clinical use, with more promising lipid-based nanoparticles currently undergoing different phases of clinical trials. Most of these lipid-based nanoparticles have been designed to exploit the EPR effects to enhance their efficacy and tolerability [86].

With the explosive increase in preclinical studies investigating the effectiveness of nanoparticles, it is important to unify the reporting standards of all the efficacy, toxicity, pharmacokinetics and biodistribution parameters necessary for the nanoscience community to make unbiased evaluations of the effectiveness of these nanoparticles. While a false negative toxicity profile due to the use of poorly predictive preclinical studies may lead to products being potentially harmful to patients, erroneous toxicity signals may also prevent the development of potentially safe drugs. Similarly, overestimation of the efficacy of nanoparticles may put patients participating in clinical trials at risk of ineffective treatments $[302,303]$. Thus, standardizing the research protocols and reporting criteria will certainly enhance the clinical translatability of nanoparticles. In fact, the FDA has established the Nanotechnology Characterization Lab (NCL) and provided the standardized analytical cascade specifying the key preclinical characterizations as a guide for the nanoscience community to gather the in vitro and in vivo data necessary for Investigational New Drug (IND) applications [83]. However, these discrepancies in reporting standards, particularly the pharmacokinetics, biodistribution and toxicity data, were observed clearly in the studies summarized in Table 4 , where a number of studies only reported the efficacy of their nanoparticles.

The number of nanomedicines that have successfully translated to the clinical settings is unsatisfactory, despite a myriad of research articles reporting the superiority of nanoparticles over conventional drugs in preclinical studies. The main reason causing this attrition is the complex heterogeneity in EPR effects, varying over time during tumor development, differing significantly between animal models and humans, among different tumors from the same origin, and among tumors within the same individual [86]. The role and complexity of endocytosis in the uptake of nanoparticles have also been reviewed recently, highlighting the limitations of present experimental methods in understanding the internalization mechanisms of nanoparticles and how they reach the intended site of action [304,305]. Interestingly, a recent study discovered that a threshold dose of 1 trillion nanoparticles overwhelmed the liver and dramatically increased the tumor delivery efficiency of nanoparticles from $0.7 \%$ to $12 \%$ of the injected dose (\% ID) in mice [306]. Moreover, a recent study challenged the long-established EPR effects by providing evidence that the 
dominant transport mechanism of colloidal gold nanoparticles into solid tumors is through active transcytosis by endothelial cells [84]. Understanding these nanoparticle-biological (nano-bio) interactions will allow us to harness the true potential of nanoparticles and ensure that nano-concepts have a macro-impact in clinical settings.

Author Contributions: Writing—original draft preparation: J.S.L. and L.K.S.T.; writing—review and editing: W.L.L., L.C.M., N.K., C.W.H. and J.B.F.; Conceptualization: W.L.L., Y.S.O. and B.H.G. All authors have read and agreed to the published version of the manuscript.

Funding: The work is funded by Monash Global Asia in the 21st Century (GA21) research grant (GA-ST-21-L03).

Conflicts of Interest: The authors declare no conflict of interest.

\section{Abbreviations}

$\begin{array}{ll}\text { 0-D } & \text { No Dimension } \\ \text { 1-D } & \text { One Dimension } \\ \text { 2-D } & \text { Two-Dimension } \\ \text { ABC } & \text { ATP-Binding Cassette } \\ \text { ABCB1 } & \text { ABC Sub-Family B Member 1 } \\ \text { ABCC1 } & \text { ABC transporter C1 } \\ \text { ABCG2 } & \text { ABC transporter G2 } \\ \text { ATM } & \text { Ataxia-Telangiectasia Mutated } \\ \text { ATR } & \text { Ataxia-Telangiectasia and RAD3-Related } \\ \text { AUC } & \text { Area Under The Curve } \\ \text { BAK } & \text { Bcl-2 Homologous Antagonist Killer } \\ \text { BAX } & \text { Bcl-2-Associated X Protein } \\ \text { BCL } & \text { B cell lymphoma } \\ \text { BCRP } & \text { Breast Cancer Resistance Protein } \\ \text { BH3 } & \text { Bcl-2 Homology 3 } \\ \text { BIND-014 } & \text { PSMA-Targeted Docetaxel Nanoparticles } \\ \text { CDK } & \text { Cyclin-Dependent Kinase } \\ \text { Chk2 } & \text { Checkpoint Kinase 2 } \\ \text { CL } & \text { Clearance } \\ \text { Cmax } & \text { Peak Drug Concentration } \\ \text { COVID-19 } & \text { Coronavirus Disease 2019 } \\ \text { CR } & \text { Complete Remission } \\ \text { CYP } & \text { Cytochrome P450 } \\ \text { DDR } & \text { DNA Damage Response } \\ \text { DISC } & \text { Death-Inducing Signaling Complex } \\ \text { DNA } & \text { Deoxyribonucleic Acid } \\ \text { DR3 } & \text { Death Receptor 3 } \\ \text { EGFR } & \text { Epidermal Growth Factor Receptor } \\ \text { EPR } & \text { Enhanced Permeability and Retention } \\ \text { FADD } & \text { Fas-Associated Protein With Death Domain } \\ \text { FDA } & \text { Food and Drug Administration } \\ \text { GDP } & \text { Guanosine 5'-Diphosphate } \\ \text { GTP } & \text { Guanosine 5'-Triphosphate } \\ \text { IC50 } & \text { Half-Maximal Inhibitory Concentration } \\ \text { ID } & \text { Injected Dose } \\ \text { ILs } & \text { Interleukins } \\ \text { Lys } & \text { Lysine } \\ \text { MCL-1 } & \text { Myeloid Cell Leukemia 1 } \\ & \end{array}$




$\begin{array}{ll}\text { MDR } & \text { Multidrug Resistance } \\ \text { MOMP } & \text { Mitochondria Outer Membrane Permeabilization } \\ \text { MRD } & \text { Minimal Residual Disease } \\ \text { MRE11 } & \text { Meiotic Recombination 11 Homolog 1 } \\ \text { MRI } & \text { Magnetic Resonance Imaging } \\ \text { MRN } & \text { MRE11-RAD50-NBS1 } \\ \text { mRNA } & \text { Messenger Ribonucleic Acid } \\ \text { MTD } & \text { Maximum Tolerated Dose } \\ \text { NLC } & \text { Nanostructured Lipid Carriers } \\ \text { NNI } & \text { National Nanotechnology Initiative } \\ \text { Orn } & \text { Ornithine } \\ \text { pCR } & \text { Pathological Complete Response } \\ \text { PEG } & \text { Polyethylene Glycol } \\ \text { Phe } & \text { Phenylalanine } \\ \text { PSMA } & \text { Prostate Specific Membrane Antigen } \\ \text { RAD50 } & \text { Double Strand Break Repair Protein } \\ \text { RB } & \text { Retinoblastoma } \\ \text { RES } & \text { Reticuloendothelial System } \\ \text { SAC } & \text { Spindle Assembly Checkpoint } \\ \text { SARS-CoV-2 } & \text { Severe Acute Respiratory Syndrome Coronavirus 2 } \\ \text { scFv } & \text { Single Chain Fragment Variable } \\ \text { SCLC } & \text { Small Cell Lung Cancer } \\ \text { SGT-53 } & \text { Tumor Suppressor Gene TP53/scL-p53 } \\ \text { SLN } & \text { Solid Lipid Nanoparticles } \\ \text { SN-38 } & \text { 7-Ethyl-10-Hydroxycamptothecin } \\ \text { SN-38G } & \text { SN-38 Glucuronide } \\ t_{1 / 2} & \text { Elimination half-life } \\ \text { TfR } & \text { Transferrin Receptor } \\ \text { TL1A } & \text { TNF-Like Cytokine 1A } \\ \text { TNF } & \text { Tumor Necrosis Factor } \\ \text { TOP1cc } & \text { Topoisomerase I-DNA Cleaved Complexes } \\ \text { Trp } & \text { Tryptophan } \\ \text { Tyr } & \text { Tyrosine } \\ \text { UGT1A } & \text { Uridine Diphosphate Glucuronosyltransferase 1A } \\ \text { V } & \text { Volume of Distribution } \\ \text { VYXEOS } & \text { Liposomal Cytarabine/Daunorubicin } \\ & \end{array}$

\section{References}

1. Sung, H.; Ferlay, J.; Siegel, R.L.; Laversanne, M.; Soerjomataram, I.; Jemal, A.; Bray, F. Global cancer statistics 2020: GLOBOCAN estimates of incidence and mortality worldwide for 36 cancers in 185 countries. CA Cancer J. Clin. 2021. [CrossRef]

2. $\quad$ Bryant, A.K.; Banegas, M.P.; Martinez, M.E.; Mell, L.K.; Murphy, J.D. Trends in Radiation Therapy among Cancer Survivors in the United States, 2000-2030. Cancer Epidemiol. Biomark. Prev. 2017, 26, 963-970. [CrossRef]

3. Perera, S.K.; Jacob, S.; Sullivan, R.; Barton, M. Evidence-based benchmarks for use of cancer surgery in high-income countries: A population-based analysis. Lancet Oncol. 2021, 22, 173-181. [CrossRef]

4. Wilson, B.E.; Jacob, S.; Yap, M.L.; Ferlay, J.; Bray, F.; Barton, M.B. Estimates of global chemotherapy demands and corresponding physician workforce requirements for 2018 and 2040: A population-based study. Lancet Oncol. 2019, 20, 769-780. [CrossRef]

5. Falzone, L.; Salomone, S.; Libra, M. Evolution of Cancer Pharmacological Treatments at the Turn of the Third Millennium. Front. Pharmacol. 2018, 9, 1300. [CrossRef]

6. Sharma, P.; Hu-Lieskovan, S.; Wargo, J.A.; Ribas, A. Primary, Adaptive, and Acquired Resistance to Cancer Immunotherapy. Cell 2017, 168, 707-723. [CrossRef]

7. Li, F.S.; Weng, J.K. Demystifying traditional herbal medicine with modern approach. Nat. Plants 2017, 3, 17109. [CrossRef]

8. Atanasov, A.G.; Zotchev, S.B.; Dirsch, V.M.; International Natural Product Sciences Taskforce; Supuran, C.T. Natural products in drug discovery: Advances and opportunities. Nat. Rev. Drug Discov. 2021, 20, 200-216. [CrossRef] [PubMed]

9. Newman, D.J.; Cragg, G.M. Natural Products as Sources of New Drugs from 1981 to 2014. J. Nat. Prod. 2016, 79, 629-661. [CrossRef] [PubMed]

10. Davison, E.K.; Brimble, M.A. Natural product derived privileged scaffolds in drug discovery. Curr. Opin Chem Biol. 2019, 52, 1-8. [CrossRef] [PubMed] 
11. Eguchi, R.; Ono, N.; Hirai Morita, A.; Katsuragi, T.; Nakamura, S.; Huang, M.; Altaf-Ul-Amin, M.; Kanaya, S. Classification of alkaloids according to the starting substances of their biosynthetic pathways using graph convolutional neural networks. BMC Bioinform. 2019, 20, 380. [CrossRef] [PubMed]

12. Ehrenworth, A.M.; Peralta-Yahya, P. Accelerating the semisynthesis of alkaloid-based drugs through metabolic engineering. Nat. Chem. Biol. 2017, 13, 249-258. [CrossRef] [PubMed]

13. Bharate, S.S.; Mignani, S.; Vishwakarma, R.A. Why Are the Majority of Active Compounds in the CNS Domain Natural Products? A Critical Analysis. J. Med. Chem. 2018, 61, 10345-10374. [CrossRef]

14. Reuvers, T.G.A.; Kanaar, R.; Nonnekens, J. DNA Damage-Inducing Anticancer Therapies: From Global to Precision Damage. Cancers 2020, 12, 2098. [CrossRef]

15. Steinmetz, M.O.; Prota, A.E. Microtubule-Targeting Agents: Strategies to Hijack the Cytoskeleton. Trends Cell Biol. 2018, 28, 776-792. [CrossRef] [PubMed]

16. Douer, D. Efficacy and Safety of Vincristine Sulfate Liposome Injection in the Treatment of Adult Acute Lymphocytic Leukemia. Oncologist 2016, 21, 840-847. [CrossRef]

17. Innocenti, F.; Schilsky, R.L.; Ramirez, J.; Janisch, L.; Undevia, S.; House, L.K.; Das, S.; Wu, K.; Turcich, M.; Marsh, R.; et al. Dose-finding and pharmacokinetic study to optimize the dosing of irinotecan according to the UGT1A1 genotype of patients with cancer. J. Clin. Oncol. 2014, 32, 2328-2334. [CrossRef]

18. Rosello, S.; Blasco, I.; Garcia Fabregat, L.; Cervantes, A.; Jordan, K.; Committee, E.G. Management of infusion reactions to systemic anticancer therapy: ESMO Clinical Practice Guidelines. Ann. Oncol. 2017, 28, iv100-iv118. [CrossRef]

19. Blanco, E.; Shen, H.; Ferrari, M. Principles of nanoparticle design for overcoming biological barriers to drug delivery. Nat. Biotechnol. 2015, 33, 941-951. [CrossRef] [PubMed]

20. Pelaz, B.; Alexiou, C.; Alvarez-Puebla, R.A.; Alves, F.; Andrews, A.M.; Ashraf, S.; Balogh, L.P.; Ballerini, L.; Bestetti, A.; Brendel, C.; et al. Diverse Applications of Nanomedicine. ACS Nano 2017, 11, 2313-2381. [CrossRef]

21. Tang, W.; Fan, W.; Lau, J.; Deng, L.; Shen, Z.; Chen, X. Emerging blood-brain-barrier-crossing nanotechnology for brain cancer theranostics. Chem. Soc. Rev. 2019, 48, 2967-3014. [CrossRef]

22. Lancet, J.E.; Uy, G.L.; Cortes, J.E.; Newell, L.F.; Lin, T.L.; Ritchie, E.K.; Stuart, R.K.; Strickland, S.A.; Hogge, D.; Solomon, S.R.; et al. CPX-351 (cytarabine and daunorubicin) Liposome for Injection Versus Conventional Cytarabine Plus Daunorubicin in Older Patients With Newly Diagnosed Secondary Acute Myeloid Leukemia. J. Clin. Oncol. 2018, 36, 2684-2692. [CrossRef]

23. Pattni, B.S.; Chupin, V.V.; Torchilin, V.P. New Developments in Liposomal Drug Delivery. Chem. Rev. 2015, 115, 10938-10966. [CrossRef]

24. Suk, J.S.; Xu, Q.; Kim, N.; Hanes, J.; Ensign, L.M. PEGylation as a strategy for improving nanoparticle-based drug and gene delivery. Adv. Drug Deliv. Rev. 2016, 99, 28-51. [CrossRef]

25. Shi, J.; Kantoff, P.W.; Wooster, R.; Farokhzad, O.C. Cancer nanomedicine: Progress, challenges and opportunities. Nat. Rev. Cancer 2017, 17, 20-37. [CrossRef]

26. Mitchell, M.J.; Billingsley, M.M.; Haley, R.M.; Wechsler, M.E.; Peppas, N.A.; Langer, R. Engineering precision nanoparticles for drug delivery. Nat. Rev. Drug Discov. 2021, 20, 101-124. [CrossRef] [PubMed]

27. Bayda, S.; Adeel, M.; Tuccinardi, T.; Cordani, M.; Rizzolio, F. The History of Nanoscience and Nanotechnology: From ChemicalPhysical Applications to Nanomedicine. Molecules 2019, 25, 112. [CrossRef] [PubMed]

28. Roco, M.C. The long view of nanotechnology development: The National Nanotechnology Initiative at 10 years. J. Nanopart. Res. 2011, 13, 427-445. [CrossRef]

29. Porter, A.L.; Youtie, J. How interdisciplinary is nanotechnology? J. Nanopart. Res. 2009, 11, 1023-1041. [CrossRef] [PubMed]

30. Chen, H.; Gu, Z.; An, H.; Chen, C.; Chen, J.; Cui, R.; Chen, S.; Chen, W.; Chen, X.; Chen, X.; et al. Precise nanomedicine for intelligent therapy of cancer. Sci. China Chem. 2018, 61, 1503-1552. [CrossRef]

31. Van der Meel, R.; Sulheim, E.; Shi, Y.; Kiessling, F.; Mulder, W.J.M.; Lammers, T. Smart cancer nanomedicine. Nat. Nanotechnol. 2019, 14, 1007-1017. [CrossRef] [PubMed]

32. Zaytseva, O.; Neumann, G. Carbon nanomaterials: Production, impact on plant development, agricultural and environmental applications. Chem. Biol. Technol. Agric. 2016, 3, 17. [CrossRef]

33. Liu, Z.; Robinson, J.T.; Tabakman, S.M.; Yang, K.; Dai, H. Carbon materials for drug delivery \& cancer therapy. Mater. Today 2011, 14, 316-323. [CrossRef]

34. Patel, K.D.; Singh, R.K.; Kim, H.-W. Carbon-based nanomaterials as an emerging platform for theranostics. Mater. Horiz. 2019, 6, 434-469. [CrossRef]

35. Mody, V.V.; Siwale, R.; Singh, A.; Mody, H.R. Introduction to metallic nanoparticles. J. Pharm. Bioallied. Sci. 2010, 2, 282-289. [CrossRef] [PubMed]

36. Saleh, T.A. Nanomaterials: Classification, properties, and environmental toxicities. Environ. Technol. Innov. 2020, $20,101067$. [CrossRef]

37. Palazzolo, S.; Bayda, S.; Hadla, M.; Caligiuri, I.; Corona, G.; Toffoli, G.; Rizzolio, F. The Clinical Translation of Organic Nanomaterials for Cancer Therapy: A Focus on Polymeric Nanoparticles, Micelles, Liposomes and Exosomes. Curr. Med. Chem. 2018, 25, 4224-4268. [CrossRef]

38. Chen, Q.; Wang, C.; Zhang, X.; Chen, G.; Hu, Q.; Li, H.; Wang, J.; Wen, D.; Zhang, Y.; Lu, Y.; et al. In situ sprayed bioresponsive immunotherapeutic gel for post-surgical cancer treatment. Nat. Nanotechnol. 2019, 14, 89-97. [CrossRef] 
39. Pratt, E.C.; Shaffer, T.M.; Zhang, Q.; Drain, C.M.; Grimm, J. Nanoparticles as multimodal photon transducers of ionizing radiation. Nat. Nanotechnol. 2018, 13, 418-426. [CrossRef]

40. Yaari, Z.; da Silva, D.; Zinger, A.; Goldman, E.; Kajal, A.; Tshuva, R.; Barak, E.; Dahan, N.; Hershkovitz, D.; Goldfeder, M.; et al. Theranostic barcoded nanoparticles for personalized cancer medicine. Nat. Commun. 2016, 7, 13325. [CrossRef]

41. Petersen, G.H.; Alzghari, S.K.; Chee, W.; Sankari, S.S.; La-Beck, N.M. Meta-analysis of clinical and preclinical studies comparing the anticancer efficacy of liposomal versus conventional non-liposomal doxorubicin. J. Control Release 2016, 232, 255-264. [CrossRef] [PubMed]

42. Trujillo-Alonso, V.; Pratt, E.C.; Zong, H.; Lara-Martinez, A.; Kaittanis, C.; Rabie, M.O.; Longo, V.; Becker, M.W.; Roboz, G.J.; Grimm, J.; et al. FDA-approved ferumoxytol displays anti-leukaemia efficacy against cells with low ferroportin levels. Nat. Nanotechnol. 2019, 14, 616-622. [CrossRef]

43. Untch, M.; Jackisch, C.; Schneeweiss, A.; Conrad, B.; Aktas, B.; Denkert, C.; Eidtmann, H.; Wiebringhaus, H.; Kummel, S.; Hilfrich, J.; et al. Nab-paclitaxel versus solvent-based paclitaxel in neoadjuvant chemotherapy for early breast cancer (GeparSeptoGBG 69): A randomised, phase 3 trial. Lancet Oncol. 2016, 17, 345-356. [CrossRef]

44. Tardi, P.; Johnstone, S.; Harasym, N.; Xie, S.; Harasym, T.; Zisman, N.; Harvie, P.; Bermudes, D.; Mayer, L. In vivo maintenance of synergistic cytarabine:daunorubicin ratios greatly enhances therapeutic efficacy. Leuk. Res. 2009, 33, 129-139. [CrossRef]

45. Anselmo, A.C.; Mitragotri, S. Nanoparticles in the clinic: An update. Bioeng. Transl. Med. 2019, 4, e10143. [CrossRef] [PubMed]

46. Fumoto, S.; Nishida, K. Co-delivery Systems of Multiple Drugs Using Nanotechnology for Future Cancer Therapy. Chem. Pharm. Bull. 2020, 68, 603-612. [CrossRef]

47. Kang, L.; Gao, Z.; Huang, W.; Jin, M.; Wang, Q. Nanocarrier-mediated co-delivery of chemotherapeutic drugs and gene agents for cancer treatment. Acta Pharm. Sin. B 2015, 5, 169-175. [CrossRef] [PubMed]

48. Liu, Q.; Wang, C.; Zheng, Y.; Zhao, Y.; Wang, Y.; Hao, J.; Zhao, X.; Yi, K.; Shi, L.; Kang, C.; et al. Virus-like nanoparticle as a co-delivery system to enhance efficacy of CRISPR/Cas9-based cancer immunotherapy. Biomaterials 2020, 258, 120275. [CrossRef]

49. Meng, Q.Y.; Cong, H.L.; Hu, H.; Xu, F.J. Rational design and latest advances of codelivery systems for cancer therapy. Mater. Today Bio. 2020, 7, 100056. [CrossRef]

50. Song, Q.; Yin, Y.; Shang, L.; Wu, T.; Zhang, D.; Kong, M.; Zhao, Y.; He, Y.; Tan, S.; Guo, Y.; et al. Tumor Microenvironment Responsive Nanogel for the Combinatorial Antitumor Effect of Chemotherapy and Immunotherapy. Nano Lett. 2017, 17, 6366-6375. [CrossRef]

51. Wang, J.; Li, Y.; Nie, G. Multifunctional biomolecule nanostructures for cancer therapy. Nat. Rev. Mater. 2021. [CrossRef]

52. Liu, J.; Song, L.; Liu, S.; Zhao, S.; Jiang, Q.; Ding, B. A Tailored DNA Nanoplatform for Synergistic RNAi-/Chemotherapy of Multidrug-Resistant Tumors. Angew. Chem. Int. Ed. Engl. 2018, 57, 15486-15490. [CrossRef]

53. Ortíz, R.; Quiñonero, F.; García-Pinel, B.; Fuel, M.; Mesas, C.; Cabeza, L.; Melguizo, C.; Prados, J. Nanomedicine to Overcome Multidrug Resistance Mechanisms in Colon and Pancreatic Cancer: Recent Progress. Cancers 2021, 13, 2058. [CrossRef] [PubMed]

54. Baden, L.R.; El Sahly, H.M.; Essink, B.; Kotloff, K.; Frey, S.; Novak, R.; Diemert, D.; Spector, S.A.; Rouphael, N.; Creech, C.B.; et al. Efficacy and Safety of the mRNA-1273 SARS-CoV-2 Vaccine. N. Engl. J. Med. 2021, 384, 403-416. [CrossRef]

55. Polack, F.P.; Thomas, S.J.; Kitchin, N.; Absalon, J.; Gurtman, A.; Lockhart, S.; Perez, J.L.; Perez Marc, G.; Moreira, E.D.; Zerbini, C.; et al. Safety and Efficacy of the BNT162b2 mRNA Covid-19 Vaccine. N. Engl J. Med. 2020, 383, 2603-2615. [CrossRef] [PubMed]

56. Chung, Y.H.; Beiss, V.; Fiering, S.N.; Steinmetz, N.F. COVID-19 Vaccine Frontrunners and Their Nanotechnology Design. ACS Nano 2020, 14, 12522-12537. [CrossRef]

57. Kim, J.H.; Marks, F.; Clemens, J.D. Looking beyond COVID-19 vaccine phase 3 trials. Nat. Med. 2021, 27, 205-211. [CrossRef]

58. Pantel, K.; Alix-Panabieres, C. Liquid biopsy and minimal residual disease - latest advances and implications for cure. Nat. Rev. Clin. Oncol. 2019, 16, 409-424. [CrossRef]

59. Pan, H.; Gray, R.; Braybrooke, J.; Davies, C.; Taylor, C.; McGale, P.; Peto, R.; Pritchard, K.I.; Bergh, J.; Dowsett, M.; et al. 20-Year Risks of Breast-Cancer Recurrence after Stopping Endocrine Therapy at 5 Years. N. Engl. J. Med. 2017, 377, 1836-1846. [CrossRef] [PubMed]

60. Lukianova-Hleb, E.Y.; Kim, Y.S.; Belatsarkouski, I.; Gillenwater, A.M.; O’Neill, B.E.; Lapotko, D.O. Intraoperative diagnostics and elimination of residual microtumours with plasmonic nanobubbles. Nat. Nanotechnol. 2016, 11, 525-532. [CrossRef] [PubMed]

61. Dyett, B.P.; Li, M.; Zhao, H.; Zhang, X. Plasmonic Nanobubbles in "Armored" Surface Nanodroplets. J. Phys. Chem. C 2019, 123, 29866-29874. [CrossRef]

62. Anselmo, A.C.; Mitragotri, S. An overview of clinical and commercial impact of drug delivery systems. J. Control Release 2014, 190, 15-28. [CrossRef]

63. Jin, J.; Sklar, G.E.; Min Sen Oh, V.; Chuen Li, S. Factors affecting therapeutic compliance: A review from the patient's perspective. Clin. Risk Manag. 2008, 4, 269-286. [CrossRef]

64. Date, A.A.; Hanes, J.; Ensign, L.M. Nanoparticles for oral delivery: Design, evaluation and state-of-the-art. J. Control Release 2016, 240, 504-526. [CrossRef] [PubMed]

65. Patra, J.K.; Das, G.; Fraceto, L.F.; Campos, E.V.R.; Rodriguez-Torres, M.D.P.; Acosta-Torres, L.S.; Diaz-Torres, L.A.; Grillo, R.; Swamy, M.K.; Sharma, S.; et al. Nano based drug delivery systems: Recent developments and future prospects. J. Nanobiotechnol. 2018, 16, 71. [CrossRef] 
66. He, H.; Lu, Y.; Qi, J.; Zhu, Q.; Chen, Z.; Wu, W. Adapting liposomes for oral drug delivery. Acta Pharm. Sin. B 2019, 9, 36-48. [CrossRef] [PubMed]

67. Plaza-Oliver, M.; Santander-Ortega, M.J.; Lozano, M.V. Current approaches in lipid-based nanocarriers for oral drug delivery. Drug Deliv. Transl. Res. 2021, 11, 471-497. [CrossRef] [PubMed]

68. Cho, H.J.; Park, J.W.; Yoon, I.S.; Kim, D.D. Surface-modified solid lipid nanoparticles for oral delivery of docetaxel: Enhanced intestinal absorption and lymphatic uptake. Int. J. Nanomed. 2014, 9, 495-504. [CrossRef]

69. Jain, S.; Kumar, D.; Swarnakar, N.K.; Thanki, K. Polyelectrolyte stabilized multilayered liposomes for oral delivery of paclitaxel. Biomaterials 2012, 33, 6758-6768. [CrossRef] [PubMed]

70. Pooja, D.; Kulhari, H.; Kuncha, M.; Rachamalla, S.S.; Adams, D.J.; Bansal, V.; Sistla, R. Improving Efficacy, Oral Bioavailability, and Delivery of Paclitaxel Using Protein-Grafted Solid Lipid Nanoparticles. Mol. Pharm. 2016, 13, 3903-3912. [CrossRef]

71. Seo, Y.G.; Kim, D.H.; Ramasamy, T.; Kim, J.H.; Marasini, N.; Oh, Y.K.; Kim, D.W.; Kim, J.K.; Yong, C.S.; Kim, J.O.; et al. Development of docetaxel-loaded solid self-nanoemulsifying drug delivery system (SNEDDS) for enhanced chemotherapeutic effect. Int. J. Pharm. 2013, 452, 412-420. [CrossRef] [PubMed]

72. Garg, B.; Katare, O.P.; Beg, S.; Lohan, S.; Singh, B. Systematic development of solid self-nanoemulsifying oily formulations (S-SNEOFs) for enhancing the oral bioavailability and intestinal lymphatic uptake of lopinavir. Colloids Surf. B Biointerfaces 2016, 141, 611-622. [CrossRef] [PubMed]

73. Makwana, V.; Jain, R.; Patel, K.; Nivsarkar, M.; Joshi, A. Solid lipid nanoparticles (SLN) of Efavirenz as lymph targeting drug delivery system: Elucidation of mechanism of uptake using chylomicron flow blocking approach. Int. J. Pharm. 2015, 495, 439-446. [CrossRef]

74. Diwan, R.; Ravi, P.R.; Pathare, N.S.; Aggarwal, V. Pharmacodynamic, pharmacokinetic and physical characterization of cilnidipine loaded solid lipid nanoparticles for oral delivery optimized using the principles of design of experiments. Colloids Surf. B Biointerfaces 2020, 193, 111073. [CrossRef]

75. Dening, T.J.; Rao, S.; Thomas, N.; Prestidge, C.A. Oral nanomedicine approaches for the treatment of psychiatric illnesses. J. Control Release 2016, 223, 137-156. [CrossRef]

76. Eleraky, N.E.; Omar, M.M.; Mahmoud, H.A.; Abou-Taleb, H.A. Nanostructured Lipid Carriers to Mediate Brain Delivery of Temazepam: Design and In Vivo Study. Pharmaceutics 2020, 12, 451. [CrossRef] [PubMed]

77. Brown, T.D.; Whitehead, K.A.; Mitragotri, S. Materials for oral delivery of proteins and peptides. Nat. Rev. Mater. 2020, 5, 127. [CrossRef]

78. Bertrand, N.; Wu, J.; Xu, X.; Kamaly, N.; Farokhzad, O.C. Cancer nanotechnology: The impact of passive and active targeting in the era of modern cancer biology. Adv. Drug Deliv. Rev. 2014, 66, 2-25. [CrossRef]

79. Hashizume, H.; Baluk, P.; Morikawa, S.; McLean, J.W.; Thurston, G.; Roberge, S.; Jain, R.K.; McDonald, D.M. Openings between defective endothelial cells explain tumor vessel leakiness. Am. J. Pathol. 2000, 156, 1363-1380. [CrossRef]

80. Padera, T.P.; Kadambi, A.; di Tomaso, E.; Carreira, C.M.; Brown, E.B.; Boucher, Y.; Choi, N.C.; Mathisen, D.; Wain, J.; Mark, E.J.; et al. Lymphatic metastasis in the absence of functional intratumor lymphatics. Science 2002, 296, 1883-1886. [CrossRef]

81. Schwartz, S., Jr. Unmet needs in developing nanoparticles for precision medicine. Nanomedicine 2017, 12, 271-274. [CrossRef]

82. Wilhelm, S.; Tavares, A.J.; Dai, Q.; Ohta, S.; Audet, J.; Dvorak, H.F.; Chan, W.C.W. Analysis of nanoparticle delivery to tumours. Nat. Rev. Mater. 2016, 1, 16014. [CrossRef]

83. Rosenblum, D.; Joshi, N.; Tao, W.; Karp, J.M.; Peer, D. Progress and challenges towards targeted delivery of cancer therapeutics. Nat. Commun. 2018, 9, 1410. [CrossRef]

84. Sindhwani, S.; Syed, A.M.; Ngai, J.; Kingston, B.R.; Maiorino, L.; Rothschild, J.; MacMillan, P.; Zhang, Y.; Rajesh, N.U.; Hoang, T.; et al. The entry of nanoparticles into solid tumours. Nat. Mater. 2020, 19, 566-575. [CrossRef]

85. McNeil, S.E. Evaluation of nanomedicines: Stick to the basics. Nat. Rev. Mater. 2016, 1, 16073. [CrossRef]

86. Golombek, S.K.; May, J.N.; Theek, B.; Appold, L.; Drude, N.; Kiessling, F.; Lammers, T. Tumor targeting via EPR: Strategies to enhance patient responses. Adv. Drug Deliv. Rev. 2018, 130, 17-38. [CrossRef] [PubMed]

87. Li, J.; Burgess, D.J. Nanomedicine-based drug delivery towards tumor biological and immunological microenvironment. Acta Pharm. Sin. B 2020, 10, 2110-2124. [CrossRef]

88. Perry, J.L.; Reuter, K.G.; Luft, J.C.; Pecot, C.V.; Zamboni, W.; DeSimone, J.M. Mediating Passive Tumor Accumulation through Particle Size, Tumor Type, and Location. Nano Lett. 2017, 17, 2879-2886. [CrossRef]

89. Danhier, F. To exploit the tumor microenvironment: Since the EPR effect fails in the clinic, what is the future of nanomedicine? J. Control Release 2016, 244, 108-121. [CrossRef] [PubMed]

90. Fang, J.; Islam, W.; Maeda, H. Exploiting the dynamics of the EPR effect and strategies to improve the therapeutic effects of nanomedicines by using EPR effect enhancers. Adv. Drug Deliv. Rev. 2020, 157, 142-160. [CrossRef] [PubMed]

91. Maeda, H. The 35th Anniversary of the Discovery of EPR Effect: A New Wave of Nanomedicines for Tumor-Targeted Drug Delivery-Personal Remarks and Future Prospects. J. Pers. Med. 2021, 11, 229. [CrossRef] [PubMed]

92. Ojha, T.; Pathak, V.; Shi, Y.; Hennink, W.E.; Moonen, C.T.W.; Storm, G.; Kiessling, F.; Lammers, T. Pharmacological and physical vessel modulation strategies to improve EPR-mediated drug targeting to tumors. Adv. Drug Deliv. Rev. 2017, 119, 44-60. [CrossRef] [PubMed]

93. Izci, M.; Maksoudian, C.; Manshian, B.B.; Soenen, S.J. The Use of Alternative Strategies for Enhanced Nanoparticle Delivery to Solid Tumors. Chem. Rev. 2021, 121, 1746-1803. [CrossRef] 
94. Miller, M.A.; Gadde, S.; Pfirschke, C.; Engblom, C.; Sprachman, M.M.; Kohler, R.H.; Yang, K.S.; Laughney, A.M.; Wojtkiewicz, G.; Kamaly, N.; et al. Predicting therapeutic nanomedicine efficacy using a companion magnetic resonance imaging nanoparticle. Sci. Transl. Med. 2015, 7, 314ra183. [CrossRef] [PubMed]

95. Ramanathan, R.K.; Korn, R.L.; Raghunand, N.; Sachdev, J.C.; Newbold, R.G.; Jameson, G.; Fetterly, G.J.; Prey, J.; Klinz, S.G.; Kim, J.; et al. Correlation between Ferumoxytol Uptake in Tumor Lesions by MRI and Response to Nanoliposomal Irinotecan in Patients with Advanced Solid Tumors: A Pilot Study. Clin. Cancer Res. 2017, 23, 3638. [CrossRef]

96. Alibakhshi, A.; Abarghooi Kahaki, F.; Ahangarzadeh, S.; Yaghoobi, H.; Yarian, F.; Arezumand, R.; Ranjbari, J.; Mokhtarzadeh, A.; de la Guardia, M. Targeted cancer therapy through antibody fragments-decorated nanomedicines. J. Control Release 2017, 268, 323-334. [CrossRef]

97. Cheng, W.; Nie, J.; Xu, L.; Liang, C.; Peng, Y.; Liu, G.; Wang, T.; Mei, L.; Huang, L.; Zeng, X. pH-Sensitive Delivery Vehicle Based on Folic Acid-Conjugated Polydopamine-Modified Mesoporous Silica Nanoparticles for Targeted Cancer Therapy. ACS Appl. Mater. Interfaces 2017, 9, 18462-18473. [CrossRef]

98. Dorrance, A.M.; Neviani, P.; Ferenchak, G.J.; Huang, X.; Nicolet, D.; Maharry, K.S.; Ozer, H.G.; Hoellarbauer, P.; Khalife, J.; Hill, E.B.; et al. Targeting leukemia stem cells in vivo with antagomiR-126 nanoparticles in acute myeloid leukemia. Leukemia 2015, 29, 2143-2153. [CrossRef]

99. Li, S.; Jiang, Q.; Liu, S.; Zhang, Y.; Tian, Y.; Song, C.; Wang, J.; Zou, Y.; Anderson, G.J.; Han, J.Y.; et al. A DNA nanorobot functions as a cancer therapeutic in response to a molecular trigger in vivo. Nat. Biotechnol. 2018, 36, 258-264. [CrossRef]

100. Liang, B.; Shahbaz, M.; Wang, Y.; Gao, H.; Fang, R.; Niu, Z.; Liu, S.; Wang, B.; Sun, Q.; Niu, W.; et al. Integrinbeta6-targeted immunoliposomes mediate tumor-specific drug delivery and enhance therapeutic efficacy in colon carcinoma. Clin. Cancer Res. 2015, 21, 1183-1195. [CrossRef]

101. Wei, Y.; Gu, X.; Sun, Y.; Meng, F.; Storm, G.; Zhong, Z. Transferrin-binding peptide functionalized polymersomes mediate targeted doxorubicin delivery to colorectal cancer in vivo. J. Control Release 2020, 319, 407-415. [CrossRef]

102. Bar-Zeev, M.; Livney, Y.D.; Assaraf, Y.G. Targeted nanomedicine for cancer therapeutics: Towards precision medicine overcoming drug resistance. Drug Resist. Updates 2017, 31, 15-30. [CrossRef]

103. Juan, A.; Cimas, F.J.; Bravo, I.; Pandiella, A.; Ocaña, A.; Alonso-Moreno, C. An Overview of Antibody Conjugated Polymeric Nanoparticles for Breast Cancer Therapy. Pharmaceutics 2020, 12, 802. [CrossRef]

104. Ayo, A.; Laakkonen, P. Peptide-Based Strategies for Targeted Tumor Treatment and Imaging. Pharmaceutics 2021, $13,481$. [CrossRef]

105. Mi, P.; Cabral, H.; Kataoka, K. Ligand-Installed Nanocarriers toward Precision Therapy. Adv. Mater. 2020, 32, e1902604. [CrossRef] [PubMed]

106. Wu, P.H.; Opadele, A.E.; Onodera, Y.; Nam, J.M. Targeting Integrins in Cancer Nanomedicine: Applications in Cancer Diagnosis and Therapy. Cancers 2019, 11, 1783. [CrossRef]

107. Lam, F.C.; Morton, S.W.; Wyckoff, J.; Vu Han, T.-L.; Hwang, M.K.; Maffa, A.; Balkanska-Sinclair, E.; Yaffe, M.B.; Floyd, S.R.; Hammond, P.T. Enhanced efficacy of combined temozolomide and bromodomain inhibitor therapy for gliomas using targeted nanoparticles. Nat. Commun. 2018, 9, 1991. [CrossRef] [PubMed]

108. Lundquist, P.; Artursson, P. Oral absorption of peptides and nanoparticles across the human intestine: Opportunities, limitations and studies in human tissues. Adv. Drug Deliv. Rev. 2016, 106, 256-276. [CrossRef] [PubMed]

109. Terstappen, G.C.; Meyer, A.H.; Bell, R.D.; Zhang, W. Strategies for delivering therapeutics across the blood-brain barrier. Nat. Rev. Drug Discov. 2021, 20, 362-383. [CrossRef] [PubMed]

110. Huang, X.; Peng, X.; Wang, Y.; Wang, Y.; Shin, D.M.; El-Sayed, M.A.; Nie, S. A reexamination of active and passive tumor targeting by using rod-shaped gold nanocrystals and covalently conjugated peptide ligands. ACS Nano 2010, 4, 5887-5896. [CrossRef] [PubMed]

111. Kunjachan, S.; Pola, R.; Gremse, F.; Theek, B.; Ehling, J.; Moeckel, D.; Hermanns-Sachweh, B.; Pechar, M.; Ulbrich, K.; Hennink, W.E.; et al. Passive versus Active Tumor Targeting Using RGD- and NGR-Modified Polymeric Nanomedicines. Nano Lett. 2014, 14, 972-981. [CrossRef]

112. Sykes, E.A.; Chen, J.; Zheng, G.; Chan, W.C.W. Investigating the Impact of Nanoparticle Size on Active and Passive Tumor Targeting Efficiency. ACS Nano 2014, 8, 5696-5706. [CrossRef] [PubMed]

113. Autio, K.A.; Dreicer, R.; Anderson, J.; Garcia, J.A.; Alva, A.; Hart, L.L.; Milowsky, M.I.; Posadas, E.M.; Ryan, C.J.; Graf, R.P.; et al. Safety and Efficacy of BIND-014, a Docetaxel Nanoparticle Targeting Prostate-Specific Membrane Antigen for Patients With Metastatic Castration-Resistant Prostate Cancer: A Phase 2 Clinical Trial. JAMA Oncol. 2018, 4, 1344-1351. [CrossRef]

114. Von Hoff, D.D.; Mita, M.M.; Ramanathan, R.K.; Weiss, G.J.; Mita, A.C.; LoRusso, P.M.; Burris, H.A., III; Hart, L.L.; Low, S.C.; Parsons, D.M.; et al. Phase I Study of PSMA-Targeted Docetaxel-Containing Nanoparticle BIND-014 in Patients with Advanced Solid Tumors. Clin. Cancer Res. 2016, 22, 3157-3163. [CrossRef] [PubMed]

115. Pirollo, K.F.; Nemunaitis, J.; Leung, P.K.; Nunan, R.; Adams, J.; Chang, E.H. Safety and Efficacy in Advanced Solid Tumors of a Targeted Nanocomplex Carrying the p53 Gene Used in Combination with Docetaxel: A Phase 1b Study. Mol. Ther. 2016, 24, 1697-1706. [CrossRef]

116. Siefker-Radtke, A.; Zhang, X.Q.; Guo, C.C.; Shen, Y.; Pirollo, K.F.; Sabir, S.; Leung, C.; Leong-Wu, C.; Ling, C.M.; Chang, E.H.; et al. A Phase 1 Study of a Tumor-targeted Systemic Nanodelivery System, SGT-94, in Genitourinary Cancers. Mol. Ther. 2016, 24, 1484-1491. [CrossRef] 
117. Mamot, C.; Ritschard, R.; Wicki, A.; Stehle, G.; Dieterle, T.; Bubendorf, L.; Hilker, C.; Deuster, S.; Herrmann, R.; Rochlitz, C. Tolerability, safety, pharmacokinetics, and efficacy of doxorubicin-loaded anti-EGFR immunoliposomes in advanced solid tumours: A phase 1 dose-escalation study. Lancet Oncol. 2012, 13, 1234-1241. [CrossRef]

118. Sanz-Ortega, L.; Rojas, J.M.; Barber, D.F. Improving Tumor Retention of Effector Cells in Adoptive Cell Transfer Therapies by Magnetic Targeting. Pharmaceutics 2020, 12, 812. [CrossRef]

119. Senapati, S.; Mahanta, A.K.; Kumar, S.; Maiti, P. Controlled drug delivery vehicles for cancer treatment and their performance. Signal Transduct. Target. Ther. 2018, 3, 7. [CrossRef] [PubMed]

120. Gilabert-Oriol, R.; Ryan, G.M.; Leung, A.W.Y.; Firmino, N.S.; Bennewith, K.L.; Bally, M.B. Liposomal Formulations to Modulate the Tumour Microenvironment and Antitumour Immune Response. Int. J. Mol. Sci. 2018, 19, 2922. [CrossRef] [PubMed]

121. Chen, J.; Li, W.; Yao, H.; Xu, J. Insights into drug discovery from natural products through structural modification. Fitoterapia 2015, 103, 231-241. [CrossRef]

122. Ghadi, R.; Dand, N. BCS class IV drugs: Highly notorious candidates for formulation development. J. Control Release 2017, 248, 71-95. [CrossRef] [PubMed]

123. Basmadjian, C.; Zhao, Q.; Bentouhami, E.; Djehal, A.; Nebigil, C.G.; Johnson, R.A.; Serova, M.; de Gramont, A.; Faivre, S.; Raymond, E.; et al. Cancer wars: Natural products strike back. Front. Chem. 2014, 2, 20. [CrossRef] [PubMed]

124. Yang, L.; Stockigt, J. Trends for diverse production strategies of plant medicinal alkaloids. Nat. Prod. Rep. 2010, 27, 1469-1479. [CrossRef]

125. Conroy, T.; Hammel, P.; Hebbar, M.; Ben Abdelghani, M.; Wei, A.C.; Raoul, J.L.; Chone, L.; Francois, E.; Artru, P.; Biagi, J.J.; et al. FOLFIRINOX or Gemcitabine as Adjuvant Therapy for Pancreatic Cancer. N. Engl. J. Med. 2018, 379, 2395-2406. [CrossRef] [PubMed]

126. Socinski, M.A.; Jotte, R.M.; Cappuzzo, F.; Orlandi, F.; Stroyakovskiy, D.; Nogami, N.; Rodriguez-Abreu, D.; Moro-Sibilot, D.; Thomas, C.A.; Barlesi, F.; et al. Atezolizumab for First-Line Treatment of Metastatic Nonsquamous NSCLC. N. Engl. J. Med. 2018, 378, 2288-2301. [CrossRef]

127. Cortinovis, D.; Bidoli, P.; Canova, S.; Colonese, F.; Gemelli, M.; Lavitrano, M.L.; Banna, G.L.; Liu, S.V.; Morabito, A. Novel Cytotoxic Chemotherapies in Small Cell Lung Carcinoma. Cancers 2021, 13, 1152. [CrossRef]

128. Sweeney, C.J.; Chen, Y.H.; Carducci, M.; Liu, G.; Jarrard, D.F.; Eisenberger, M.; Wong, Y.N.; Hahn, N.; Kohli, M.; Cooney, M.M.; et al. Chemohormonal Therapy in Metastatic Hormone-Sensitive Prostate Cancer. N. Engl. J. Med. 2015, 373, 737-746. [CrossRef]

129. Connors, J.M.; Jurczak, W.; Straus, D.J.; Ansell, S.M.; Kim, W.S.; Gallamini, A.; Younes, A.; Alekseev, S.; Illes, A.; Picardi, M.; et al Brentuximab Vedotin with Chemotherapy for Stage III or IV Hodgkin's Lymphoma. N. Engl. J. Med. 2018, 378, 331-344. [CrossRef]

130. Hanahan, D.; Weinberg, R.A. Hallmarks of cancer: The next generation. Cell 2011, 144, 646-674. [CrossRef]

131. Macheret, M.; Halazonetis, T.D. DNA replication stress as a hallmark of cancer. Annu. Rev. Pathol. 2015, 10, 425-448. [CrossRef] [PubMed]

132. Hanahan, D. Rethinking the war on cancer. Lancet 2014, 383, 558-563. [CrossRef]

133. Barisic, M.; Silva e Sousa, R.; Tripathy, S.K.; Magiera, M.M.; Zaytsev, A.V.; Pereira, A.L.; Janke, C.; Grishchuk, E.L.; Maiato, H. Mitosis. Microtubule detyrosination guides chromosomes during mitosis. Science 2015, 348, 799-803. [CrossRef]

134. Gui, M.; Ma, M.; Sze-Tu, E.; Wang, X.; Koh, F.; Zhong, E.D.; Berger, B.; Davis, J.H.; Dutcher, S.K.; Zhang, R.; et al. Structures of radial spokes and associated complexes important for ciliary motility. Nat. Struct. Mol. Biol. 2021, 28, 29-37. [CrossRef]

135. Kopf, A.; Renkawitz, J.; Hauschild, R.; Girkontaite, I.; Tedford, K.; Merrin, J.; Thorn-Seshold, O.; Trauner, D.; Hacker, H.; Fischer, K.D.; et al. Microtubules control cellular shape and coherence in amoeboid migrating cells. J. Cell Biol. $2020,219$. [CrossRef] [PubMed]

136. Roeles, J.; Tsiavaliaris, G. Actin-microtubule interplay coordinates spindle assembly in human oocytes. Nat. Commun. 2019, 10, 4651. [CrossRef] [PubMed]

137. Zenker, J.; White, M.D.; Templin, R.M.; Parton, R.G.; Thorn-Seshold, O.; Bissiere, S.; Plachta, N. A microtubule-organizing center directing intracellular transport in the early mouse embryo. Science 2017, 357, 925-928. [CrossRef] [PubMed]

138. Basnet, N.; Nedozralova, H.; Crevenna, A.H.; Bodakuntla, S.; Schlichthaerle, T.; Taschner, M.; Cardone, G.; Janke, C.; Jungmann, R.; Magiera, M.M.; et al. Direct induction of microtubule branching by microtubule nucleation factor SSNA1. Nat. Cell Biol. 2018, 20, 1172-1180. [CrossRef]

139. Lee, G.; Leech, G.; Rust, M.J.; Das, M.; McGorty, R.J.; Ross, J.L.; Robertson-Anderson, R.M. Myosin-driven actin-microtubule networks exhibit self-organized contractile dynamics. Sci. Adv. 2021, 7. [CrossRef]

140. Bates, D.; Eastman, A. Microtubule destabilising agents: Far more than just antimitotic anticancer drugs. Br. J. Clin. Pharm. 2017, 83, 255-268. [CrossRef] [PubMed]

141. Risinger, A.L.; Du, L. Targeting and extending the eukaryotic druggable genome with natural products: Cytoskeletal targets of natural products. Nat. Prod. Rep. 2020, 37, 634-652. [CrossRef]

142. Lyu, J.; Yang, E.J.; Zhang, B.; Wu, C.; Pardeshi, L.; Shi, C.; Mou, P.K.; Liu, Y.; Tan, K.; Shim, J.S. Synthetic lethality of RB1 and aurora A is driven by stathmin-mediated disruption of microtubule dynamics. Nat. Commun. 2020, 11, 5105. [CrossRef] [PubMed]

143. Prota, A.E.; Bargsten, K.; Zurwerra, D.; Field, J.J.; Diaz, J.F.; Altmann, K.H.; Steinmetz, M.O. Molecular mechanism of action of microtubule-stabilizing anticancer agents. Science 2013, 339, 587-590. [CrossRef] [PubMed] 
144. Risinger, A.L.; Li, J.; Bennett, M.J.; Rohena, C.C.; Peng, J.; Schriemer, D.C.; Mooberry, S.L. Taccalonolide binding to tubulin imparts microtubule stability and potent in vivo activity. Cancer Res. 2013, 73, 6780-6792. [CrossRef] [PubMed]

145. Qi, C.; Wang, X.; Shen, Z.; Chen, S.; Yu, H.; Williams, N.; Wang, G. Anti-mitotic chemotherapeutics promote apoptosis through TL1A-activated death receptor 3 in cancer cells. Cell Res. 2018, 28, 544-555. [CrossRef]

146. Henriques, A.C.; Ribeiro, D.; Pedrosa, J.; Sarmento, B.; Silva, P.M.A.; Bousbaa, H. Mitosis inhibitors in anticancer therapy: When blocking the exit becomes a solution. Cancer Lett. 2019, 440-441, 64-81. [CrossRef]

147. Dang, F.; Nie, L.; Wei, W. Ubiquitin signaling in cell cycle control and tumorigenesis. Cell Death Differ. 2021, 28, 427-438. [CrossRef] [PubMed]

148. Musacchio, A. The Molecular Biology of Spindle Assembly Checkpoint Signaling Dynamics. Curr. Biol. 2015, 25, R1002-R1018. [CrossRef]

149. Haschka, M.D.; Soratroi, C.; Kirschnek, S.; Hacker, G.; Hilbe, R.; Geley, S.; Villunger, A.; Fava, L.L. The NOXA-MCL1-BIM axis defines lifespan on extended mitotic arrest. Nat. Commun. 2015, 6, 6891. [CrossRef]

150. Topham, C.; Tighe, A.; Ly, P.; Bennett, A.; Sloss, O.; Nelson, L.; Ridgway, R.A.; Huels, D.; Littler, S.; Schandl, C.; et al. MYC Is a Major Determinant of Mitotic Cell Fate. Cancer Cell 2015, 28, 129-140. [CrossRef]

151. Wang, P.; Lindsay, J.; Owens, T.W.; Mularczyk, E.J.; Warwood, S.; Foster, F.; Streuli, C.H.; Brennan, K.; Gilmore, A.P. Phosphorylation of the proapoptotic BH3-only protein bid primes mitochondria for apoptosis during mitotic arrest. Cell Rep. 2014, 7, 661-671. [CrossRef]

152. Kalkavan, H.; Green, D.R. MOMP, cell suicide as a BCL-2 family business. Cell Death Differ. 2018, 25, 46-55. [CrossRef] [PubMed]

153. Pena-Blanco, A.; Haschka, M.D.; Jenner, A.; Zuleger, T.; Proikas-Cezanne, T.; Villunger, A.; Garcia-Saez, A.J. Drp1 modulates mitochondrial stress responses to mitotic arrest. Cell Death Differ. 2020, 27, 2620-2634. [CrossRef] [PubMed]

154. Ferlini, C.; Cicchillitti, L.; Raspaglio, G.; Bartollino, S.; Cimitan, S.; Bertucci, C.; Mozzetti, S.; Gallo, D.; Persico, M.; Fattorusso, C.; et al. Paclitaxel directly binds to Bcl-2 and functionally mimics activity of Nur77. Cancer Res. 2009, 69, 6906-6914. [CrossRef]

155. Henriques, A.C.; Silva, P.M.A.; Sarmento, B.; Bousbaa, H. Antagonizing the spindle assembly checkpoint silencing enhances paclitaxel and Navitoclax-mediated apoptosis with distinct mechanistic. Sci. Rep. 2021, 11, 4139. [CrossRef]

156. Arnst, K.E.; Banerjee, S.; Chen, H.; Deng, S.; Hwang, D.J.; Li, W.; Miller, D.D. Current advances of tubulin inhibitors as dual acting small molecules for cancer therapy. Med. Res. Rev. 2019, 39, 1398-1426. [CrossRef]

157. Gigant, B.; Wang, C.; Ravelli, R.B.; Roussi, F.; Steinmetz, M.O.; Curmi, P.A.; Sobel, A.; Knossow, M. Structural basis for the regulation of tubulin by vinblastine. Nature 2005, 435, 519-522. [CrossRef]

158. Alushin, G.M.; Lander, G.C.; Kellogg, E.H.; Zhang, R.; Baker, D.; Nogales, E. High-resolution microtubule structures reveal the structural transitions in alphabeta-tubulin upon GTP hydrolysis. Cell 2014, 157, 1117-1129. [CrossRef] [PubMed]

159. Stanton, R.A.; Gernert, K.M.; Nettles, J.H.; Aneja, R. Drugs that target dynamic microtubules: A new molecular perspective. Med. Res. Rev. 2011, 31, 443-481. [CrossRef] [PubMed]

160. Manchado, E.; Guillamot, M.; Malumbres, M. Killing cells by targeting mitosis. Cell Death Differ. 2012, 19, 369-377. [CrossRef] [PubMed]

161. Mukhtar, E.; Adhami, V.M.; Mukhtar, H. Targeting microtubules by natural agents for cancer therapy. Mol. Cancer 2014, 13, 275-284. [CrossRef]

162. Baranello, L.; Wojtowicz, D.; Cui, K.; Devaiah, B.N.; Chung, H.J.; Chan-Salis, K.Y.; Guha, R.; Wilson, K.; Zhang, X.; Zhang, H.; et al. RNA Polymerase II Regulates Topoisomerase 1 Activity to Favor Efficient Transcription. Cell 2016, 165, 357-371. [CrossRef] [PubMed]

163. Chen, S.H.; Chan, N.L.; Hsieh, T.S. New mechanistic and functional insights into DNA topoisomerases. Annu. Rev. Biochem. 2013, 82, 139-170. [CrossRef] [PubMed]

164. Pommier, Y.; Sun, Y.; Huang, S.N.; Nitiss, J.L. Roles of eukaryotic topoisomerases in transcription, replication and genomic stability. Nat. Rev. Mol. Cell Biol. 2016, 17, 703-721. [CrossRef] [PubMed]

165. Gilbert, D.C.; Chalmers, A.J.; El-Khamisy, S.F. Topoisomerase I inhibition in colorectal cancer: Biomarkers and therapeutic targets. Br. J. Cancer 2012, 106, 18-24. [CrossRef] [PubMed]

166. Roos, W.P.; Thomas, A.D.; Kaina, B. DNA damage and the balance between survival and death in cancer biology. Nat. Rev. Cancer 2016, 16, 20-33. [CrossRef] [PubMed]

167. Shiloh, Y.; Ziv, Y. The ATM protein kinase: Regulating the cellular response to genotoxic stress, and more. Nat. Rev. Mol. Cell Biol. 2013, 14, 197-210. [CrossRef] [PubMed]

168. Syed, A.; Tainer, J.A. The MRE11-RAD50-NBS1 Complex Conducts the Orchestration of Damage Signaling and Outcomes to Stress in DNA Replication and Repair. Annu. Rev. Biochem. 2018, 87, 263-294. [CrossRef] [PubMed]

169. Lecona, E.; Fernandez-Capetillo, O. Targeting ATR in cancer. Nat. Rev. Cancer 2018, 18, 586-595. [CrossRef]

170. Saldivar, J.C.; Cortez, D.; Cimprich, K.A. The essential kinase ATR: Ensuring faithful duplication of a challenging genome. Nat. Rev. Mol. Cell Biol. 2017, 18, 622-636. [CrossRef] [PubMed]

171. Stein, A.; Voigt, W.; Jordan, K. Chemotherapy-induced diarrhea: Pathophysiology, frequency and guideline-based management. Adv. Med. Oncol. 2010, 2, 51-63. [CrossRef]

172. Piao, X.; Yin, H.; Guo, S.; Wang, H.; Guo, P. RNA Nanotechnology to Solubilize Hydrophobic Antitumor Drug for Targeted Delivery. Adv. Sci. 2019, 6, 1900951. [CrossRef] 
173. Hennenfent, K.L.; Govindan, R. Novel formulations of taxanes: A review. Old wine in a new bottle? Ann. Oncol. 2006, 17, 735-749. [CrossRef] [PubMed]

174. Sparreboom, A.; Baker, S.D.; Verweij, J. Paclitaxel repackaged in an albumin-stabilized nanoparticle: Handy or just a dandy? J. Clin. Oncol. 2005, 23, 7765-7767. [CrossRef]

175. Gradishar, W.J.; Tjulandin, S.; Davidson, N.; Shaw, H.; Desai, N.; Bhar, P.; Hawkins, M.; O'Shaughnessy, J. Phase III trial of nanoparticle albumin-bound paclitaxel compared with polyethylated castor oil-based paclitaxel in women with breast cancer. J. Clin. Oncol. 2005, 23, 7794-7803. [CrossRef] [PubMed]

176. Min, Y.; Caster, J.M.; Eblan, M.J.; Wang, A.Z. Clinical Translation of Nanomedicine. Chem. Rev. 2015, 115, 11147-11190. [CrossRef] [PubMed]

177. Gelderblom, H.; Verweij, J.; Nooter, K.; Sparreboom, A. Cremophor EL: The drawbacks and advantages of vehicle selection for drug formulation. Eur. J. Cancer 2001, 37, 1590-1598. [CrossRef]

178. Van Zuylen, L.; Karlsson, M.O.; Verweij, J.; Brouwer, E.; de Bruijn, P.; Nooter, K.; Stoter, G.; Sparreboom, A. Pharmacokinetic modeling of paclitaxel encapsulation in Cremophor EL micelles. Cancer Chemother. Pharm. 2001, 47, 309-318. [CrossRef]

179. Gardner, E.R.; Dahut, W.L.; Scripture, C.D.; Jones, J.; Aragon-Ching, J.B.; Desai, N.; Hawkins, M.J.; Sparreboom, A.; Figg, W.D. Randomized crossover pharmacokinetic study of solvent-based paclitaxel and nab-paclitaxel. Clin. Cancer Res. 2008, 14, 4200-4205. [CrossRef]

180. Hormann, K.; Zimmer, A. Drug delivery and drug targeting with parenteral lipid nanoemulsions-A review. J. Control Release 2016, 223, 85-98. [CrossRef]

181. Engels, F.K.; Loos, W.J.; van der Bol, J.M.; de Bruijn, P.; Mathijssen, R.H.; Verweij, J.; Mathot, R.A. Therapeutic drug monitoring for the individualization of docetaxel dosing: A randomized pharmacokinetic study. Clin. Cancer Res. 2011, 17, 353-362. [CrossRef]

182. Engels, F.K.; Sparreboom, A.; Mathot, R.A.; Verweij, J. Potential for improvement of docetaxel-based chemotherapy: A pharmacological review. Br. J. Cancer 2005, 93, 173-177. [CrossRef]

183. Zhigaltsev, I.V.; Maurer, N.; Akhong, Q.F.; Leone, R.; Leng, E.; Wang, J.; Semple, S.C.; Cullis, P.R. Liposome-encapsulated vincristine, vinblastine and vinorelbine: A comparative study of drug loading and retention. J. Control Release 2005, 104, 103-111. [CrossRef]

184. Madsen, M.L.; Due, H.; Ejskjaer, N.; Jensen, P.; Madsen, J.; Dybkaer, K. Aspects of vincristine-induced neuropathy in hematologic malignancies: A systematic review. Cancer Chemother. Pharm. 2019, 84, 471-485. [CrossRef]

185. Starobova, H.; Vetter, I. Pathophysiology of Chemotherapy-Induced Peripheral Neuropathy. Front. Mol. Neurosci. 2017, 10, 174. [CrossRef]

186. Sacco, J.J.; Botten, J.; Macbeth, F.; Bagust, A.; Clark, P. The average body surface area of adult cancer patients in the UK: A multicentre retrospective study. PLoS ONE 2010, 5, e8933. [CrossRef]

187. O’Brien, S.; Schiller, G.; Lister, J.; Damon, L.; Goldberg, S.; Aulitzky, W.; Ben-Yehuda, D.; Stock, W.; Coutre, S.; Douer, D.; et al. High-dose vincristine sulfate liposome injection for advanced, relapsed, and refractory adult Philadelphia chromosome-negative acute lymphoblastic leukemia. J. Clin. Oncol. 2013, 31, 676-683. [CrossRef] [PubMed]

188. Terwilliger, T.; Abdul-Hay, M. Acute lymphoblastic leukemia: A comprehensive review and 2017 update. Blood Cancer J. 2017, 7, e577. [CrossRef] [PubMed]

189. Shah, N.N.; Merchant, M.S.; Cole, D.E.; Jayaprakash, N.; Bernstein, D.; Delbrook, C.; Richards, K.; Widemann, B.C.; Wayne, A.S. Vincristine Sulfate Liposomes Injection (VSLI, Marqibo(R)): Results From a Phase I Study in Children, Adolescents, and Young Adults With Refractory Solid Tumors or Leukemias. Pediatr. Blood Cancer 2016, 63, 997-1005. [CrossRef] [PubMed]

190. Silverman, J.A.; Deitcher, S.R. Marqibo(R) (vincristine sulfate liposome injection) improves the pharmacokinetics and pharmacodynamics of vincristine. Cancer Chemother. Pharm. 2013, 71, 555-564. [CrossRef]

191. Yan, Z.; Zhu, Z.L.; Qian, Z.Z.; Hu, G.; Wang, H.Q.; Liu, W.H.; Cheng, G. Pharmacokinetic characteristics of vincristine sulfate liposomes in patients with advanced solid tumors. Acta Pharm. Sin. 2012, 33, 852-858. [CrossRef] [PubMed]

192. De Man, F.M.; Goey, A.K.L.; van Schaik, R.H.N.; Mathijssen, R.H.J.; Bins, S. Individualization of Irinotecan Treatment: A Review of Pharmacokinetics, Pharmacodynamics, and Pharmacogenetics. Clin. Pharm. 2018, 57, 1229-1254. [CrossRef] [PubMed]

193. Zhu, J.; Liu, A.; Sun, X.; Liu, L.; Zhu, Y.; Zhang, T.; Jia, J.; Tan, S.; Wu, J.; Wang, X.; et al. Multicenter, Randomized, Phase III Trial of Neoadjuvant Chemoradiation With Capecitabine and Irinotecan Guided by UGT1A1 Status in Patients With Locally Advanced Rectal Cancer. J. Clin. Oncol. 2020, 38, 4231-4239. [CrossRef] [PubMed]

194. Kalra, A.V.; Kim, J.; Klinz, S.G.; Paz, N.; Cain, J.; Drummond, D.C.; Nielsen, U.B.; Fitzgerald, J.B. Preclinical activity of nanoliposomal irinotecan is governed by tumor deposition and intratumor prodrug conversion. Cancer Res. 2014, 74, 7003-7013. [CrossRef]

195. Wang-Gillam, A.; Li, C.P.; Bodoky, G.; Dean, A.; Shan, Y.S.; Jameson, G.; Macarulla, T.; Lee, K.H.; Cunningham, D.; Blanc, J.F.; et al. Nanoliposomal irinotecan with fluorouracil and folinic acid in metastatic pancreatic cancer after previous gemcitabine-based therapy (NAPOLI-1): A global, randomised, open-label, phase 3 trial. Lancet 2016, 387, 545-557. [CrossRef]

196. Silva, C.O.; Pinho, J.O.; Lopes, J.M.; Almeida, A.J.; Gaspar, M.M.; Reis, C. Current Trends in Cancer Nanotheranostics: Metallic, Polymeric, and Lipid-Based Systems. Pharmaceutics 2019, 11, 22. [CrossRef]

197. Lim, S.B.; Banerjee, A.; Önyüksel, H. Improvement of drug safety by the use of lipid-based nanocarriers. J. Control Release 2012, 163, 34-45. [CrossRef] 
198. Rahman, M.A.; Hussain, A.; Hussain, M.S.; Mirza, M.A.; Iqbal, Z. Role of excipients in successful development of selfemulsifying/microemulsifying drug delivery system (SEDDS/SMEDDS). Drug Dev. Ind. Pharm. 2013, 39, 1-19. [CrossRef]

199. Zhigaltsev, I.V.; Tam, Y.K.; Leung, A.K.K.; Cullis, P.R. Production of limit size nanoliposomal systems with potential utility as ultra-small drug delivery agents. J. Liposome Res. 2016, 26, 96-102. [CrossRef] [PubMed]

200. Cabral, H.; Matsumoto, Y.; Mizuno, K.; Chen, Q.; Murakami, M.; Kimura, M.; Terada, Y.; Kano, M.R.; Miyazono, K.; Uesaka, M.; et al. Accumulation of sub-100 nm polymeric micelles in poorly permeable tumours depends on size. Nat. Nanotechnol. 2011, 6, 815-823. [CrossRef]

201. Barenholz, Y. Doxil@—The first FDA-approved nano-drug: Lessons learned. J. Control Release 2012, 160, 117-134. [CrossRef]

202. Green, M.R.; Manikhas, G.M.; Orlov, S.; Afanasyev, B.; Makhson, A.M.; Bhar, P.; Hawkins, M.J. Abraxane, a novel Cremophor-free, albumin-bound particle form of paclitaxel for the treatment of advanced non-small-cell lung cancer. Ann. Oncol. 2006, 17, 1263-1268. [CrossRef]

203. Sercombe, L.; Veerati, T.; Moheimani, F.; Wu, S.Y.; Sood, A.K.; Hua, S. Advances and Challenges of Liposome Assisted Drug Delivery. Front. Pharm. 2015, 6, 286. [CrossRef] [PubMed]

204. Northfelt, D.W.; Dezube, B.J.; Thommes, J.A.; Miller, B.J.; Fischl, M.A.; Friedman-Kien, A.; Kaplan, L.D.; Du Mond, C.; Mamelok, R.D.; Henry, D.H. Pegylated-liposomal doxorubicin versus doxorubicin, bleomycin, and vincristine in the treatment of AIDSrelated Kaposi's sarcoma: Results of a randomized phase III clinical trial. J. Clin. Oncol. 1998, 16, 2445-2451. [CrossRef] [PubMed]

205. Yingchoncharoen, P.; Kalinowski, D.S.; Richardson, D.R. Lipid-Based Drug Delivery Systems in Cancer Therapy: What Is Available and What Is Yet to Come. Pharm. Rev. 2016, 68, 701-787. [CrossRef]

206. Amoabediny, G.; Haghiralsadat, F.; Naderinezhad, S.; Helder, M.N.; Akhoundi Kharanaghi, E.; Mohammadnejad Arough, J.; Zandieh-Doulabi, B. Overview of preparation methods of polymeric and lipid-based (niosome, solid lipid, liposome) nanoparticles: A comprehensive review. Int. J. Polym. Mater. Polym. Biomater. 2018, 67, 383-400. [CrossRef]

207. Gabizon, A.; Shmeeda, H.; Grenader, T. Pharmacological basis of pegylated liposomal doxorubicin: Impact on cancer therapy. Eur. J. Pharm. Sci. 2012, 45, 388-398. [CrossRef]

208. Steffes, V.M.; Zhang, Z.; MacDonald, S.; Crowe, J.; Ewert, K.K.; Carragher, B.; Potter, C.S.; Safinya, C.R. PEGylation of PaclitaxelLoaded Cationic Liposomes Drives Steric Stabilization of Bicelles and Vesicles thereby Enhancing Delivery and Cytotoxicity to Human Cancer Cells. ACS Appl. Mater. Interfaces 2020, 12, 151-162. [CrossRef] [PubMed]

209. Lin, W.; Kampf, N.; Goldberg, R.; Driver, M.J.; Klein, J. Poly-phosphocholinated Liposomes Form Stable Superlubrication Vectors. Langmuir 2019, 35, 6048-6054. [CrossRef] [PubMed]

210. Cao, Z.; Zhang, L.; Jiang, S. Superhydrophilic Zwitterionic Polymers Stabilize Liposomes. Langmuir 2012, 28, 11625-11632. [CrossRef]

211. Perez-Herrero, E.; Fernandez-Medarde, A. Advanced targeted therapies in cancer: Drug nanocarriers, the future of chemotherapy. Eur. J. Pharm. Biopharm. 2015, 93, 52-79. [CrossRef]

212. Lewrick, F.; Süss, R. Remote loading of anthracyclines into liposomes. Methods Mol. Biol. 2010, 605, 139-145. [CrossRef]

213. Hardiansyah, A.; Huang, L.Y.; Yang, M.C.; Liu, T.Y.; Tsai, S.C.; Yang, C.Y.; Kuo, C.Y.; Chan, T.Y.; Zou, H.M.; Lian, W.N.; et al. Magnetic liposomes for colorectal cancer cells therapy by high-frequency magnetic field treatment. Nanoscale Res. Lett. 2014, 9, 497. [CrossRef]

214. Park, J.H.; Cho, H.J.; Yoon, H.Y.; Yoon, I.S.; Ko, S.H.; Shim, J.S.; Cho, J.H.; Park, J.H.; Kim, K.; Kwon, I.C.; et al. Hyaluronic acid derivative-coated nanohybrid liposomes for cancer imaging and drug delivery. J. Control Release 2014, 174, 98-108. [CrossRef]

215. Deshpande, P.; Jhaveri, A.; Pattni, B.; Biswas, S.; Torchilin, V. Transferrin and octaarginine modified dual-functional liposomes with improved cancer cell targeting and enhanced intracellular delivery for the treatment of ovarian cancer. Drug Deliv. 2018, 25, 517-532. [CrossRef]

216. Ninomiya, K.; Kawabata, S.; Tashita, H.; Shimizu, N. Ultrasound-mediated drug delivery using liposomes modified with a thermosensitive polymer. Ultrason. Sonochem. 2014, 21, 310-316. [CrossRef]

217. Sesarman, A.; Tefas, L.; Sylvester, B.; Licarete, E.; Rauca, V.; Luput, L.; Patras, L.; Porav, S.; Banciu, M.; Porfire, A. Co-delivery of curcumin and doxorubicin in PEGylated liposomes favored the antineoplastic C26 murine colon carcinoma microenvironment. Drug Deliv. Transl. Res. 2019, 9, 260-272. [CrossRef]

218. Legut, M.; Lipka, D.; Filipczak, N.; Piwoni, A.; Kozubek, A.; Gubernator, J. Anacardic acid enhances the anticancer activity of liposomal mitoxantrone towards melanoma cell lines - in vitro studies. Int. J. Nanomed. 2014, 9, 653-668. [CrossRef]

219. Lakkadwala, S.; Singh, J. Dual Functionalized 5-Fluorouracil Liposomes as Highly Efficient Nanomedicine for Glioblastoma Treatment as Assessed in an In Vitro Brain Tumor Model. J. Pharm. Sci. 2018, 107, 2902-2913. [CrossRef] [PubMed]

220. Ge, X.; Wei, M.; He, S.; Yuan, W.-E. Advances of Non-Ionic Surfactant Vesicles (Niosomes) and Their Application in Drug Delivery. Pharmaceutics 2019, 11, 55. [CrossRef] [PubMed]

221. Ag Seleci, D.; Seleci, M.; Walter, J.-G.; Stahl, F.; Scheper, T. Niosomes as Nanoparticular Drug Carriers: Fundamentals and Recent Applications. J. Nanomater. 2016, 2016, 7372306. [CrossRef]

222. Gharbavi, M.; Amani, J.; Kheiri-Manjili, H.; Danafar, H.; Sharafi, A. Niosome: A Promising Nanocarrier for Natural Drug Delivery through Blood-Brain Barrier. Adv. Pharmacol. Sci. 2018, 2018, 6847971. [CrossRef]

223. You, L.; Liu, X.; Fang, Z.; Xu, Q.; Zhang, Q. Synthesis of multifunctional Fe3O4@PLGA-PEG nano-niosomes as a targeting carrier for treatment of cervical cancer. Mater. Sci. Eng. C Mater. Biol. Appl. 2019, 94, 291-302. [CrossRef] 
224. Abdulbaqi, I.M.; Darwis, Y.; Khan, N.A.; Assi, R.A.; Khan, A.A. Ethosomal nanocarriers: The impact of constituents and formulation techniques on ethosomal properties, in vivo studies, and clinical trials. Int. J. Nanomed. 2016, 11, $2279-2304$. [CrossRef]

225. Nainwal, N.; Jawla, S.; Singh, R.; Saharan, V.A. Transdermal applications of ethosomes-A detailed review. J. Liposome Res. 2019, 29, 103-113. [CrossRef]

226. Chen, M.; Liu, X.; Fahr, A. Skin penetration and deposition of carboxyfluorescein and temoporfin from different lipid vesicular systems: In vitro study with finite and infinite dosage application. Int. J. Pharm. 2011, 408, 223-234. [CrossRef]

227. Yu, X.; Du, L.; Li, Y.; Fu, G.; Jin, Y. Improved anti-melanoma effect of a transdermal mitoxantrone ethosome gel. Biomed. Pharm. 2015, 73, 6-11. [CrossRef] [PubMed]

228. Mishra, D.K.; Shandilya, R.; Mishra, P.K. Lipid based nanocarriers: A translational perspective. Nanomedicine 2018, 14, 2023-2050. [CrossRef] [PubMed]

229. Lu, Y.; Zhang, E.; Yang, J.; Cao, Z. Strategies to improve micelle stability for drug delivery. Nano Res. 2018, 11, 4985-4998. [CrossRef] [PubMed]

230. Koo, O.M.Y.; Rubinstein, I.; Onyüksel, H. Actively targeted low-dose camptothecin as a safe, long-acting, disease-modifying nanomedicine for rheumatoid arthritis. Pharm. Res. 2011, 28, 776-787. [CrossRef] [PubMed]

231. Krishnadas, A.; Rubinstein, I.; Önyüksel, H. Sterically Stabilized Phospholipid Mixed Micelles: In Vitro Evaluation as a Novel Carrier for Water-Insoluble Drugs. Pharm. Res. 2003, 20, 297-302. [CrossRef] [PubMed]

232. Tang, N.; Du, G.; Wang, N.; Liu, C.; Hang, H.; Liang, W. Improving penetration in tumors with nanoassemblies of phospholipids and doxorubicin. J. Natl. Cancer Inst. 2007, 99, 1004-1015. [CrossRef]

233. Kim, S.; Shi, Y.; Kim, J.Y.; Park, K.; Cheng, J.X. Overcoming the barriers in micellar drug delivery: Loading efficiency, in vivo stability, and micelle-cell interaction. Expert Opin. Drug Deliv. 2010, 7, 49-62. [CrossRef]

234. Alberts, B.; Johnson, A.; Lewis, J.; Raff, M.; Roberts, K.; Peter, W. The Lipid Bilayer. In Molecular Biology of the Cell, 4th ed.; Garland Science: New York, NY, USA, 2002.

235. Muller, R.H.; Shegokar, R.; Keck, C.M. 20 years of lipid nanoparticles (SLN and NLC): Present state of development and industrial applications. Curr. Drug Discov. Technol. 2011, 8, 207-227. [CrossRef]

236. Uner, M.; Yener, G. Importance of solid lipid nanoparticles (SLN) in various administration routes and future perspectives. Int. J. Nanomed. 2007, 2, 289-300.

237. Wang, W.; Zhang, L.; Chen, T.; Guo, W.; Bao, X.; Wang, D.; Ren, B.; Wang, H.; Li, Y.; Wang, Y.; et al. Anticancer Effects of Resveratrol-Loaded Solid Lipid Nanoparticles on Human Breast Cancer Cells. Molecules 2017, 22, 1814. [CrossRef]

238. Ghasemiyeh, P.; Mohammadi-Samani, S. Solid lipid nanoparticles and nanostructured lipid carriers as novel drug delivery systems: Applications, advantages and disadvantages. Res. Pharm. Sci. 2018, 13, 288-303. [CrossRef] [PubMed]

239. Muller, R.H.; Radtke, M.; Wissing, S.A. Nanostructured lipid matrices for improved microencapsulation of drugs. Int. J. Pharm. 2002, 242, 121-128. [CrossRef]

240. Beloqui, A.; Solinis, M.A.; Rodriguez-Gascon, A.; Almeida, A.J.; Preat, V. Nanostructured lipid carriers: Promising drug delivery systems for future clinics. Nanomedicine 2016, 12, 143-161. [CrossRef]

241. Iqbal, M.A.; Md, S.; Sahni, J.K.; Baboota, S.; Dang, S.; Ali, J. Nanostructured lipid carriers system: Recent advances in drug delivery. J. Drug Target 2012, 20, 813-830. [CrossRef]

242. Wei, Q.; Yang, Q.; Wang, Q.; Sun, C.; Zhu, Y.; Niu, Y.; Yu, J.; Xu, X. Formulation, Characterization, and Pharmacokinetic Studies of 6-Gingerol-Loaded Nanostructured Lipid Carriers. AAPS PharmSciTech 2018, 19, 3661-3669. [CrossRef] [PubMed]

243. Vakili-Ghartavol, R.; Rezayat, S.M.; Faridi-Majidi, R.; Sadri, K.; Jaafari, M.R. Optimization of Docetaxel Loading Conditions in Liposomes: Proposing potential products for metastatic breast carcinoma chemotherapy. Sci. Rep. 2020, 10, 5569. [CrossRef]

244. Zhigaltsev, I.V.; Winters, G.; Srinivasulu, M.; Crawford, J.; Wong, M.; Amankwa, L.; Waterhouse, D.; Masin, D.; Webb, M.; Harasym, N.; et al. Development of a weak-base docetaxel derivative that can be loaded into lipid nanoparticles. J. Control Release 2010, 144, 332-340. [CrossRef]

245. Chang, M.; Lu, S.; Zhang, F.; Zuo, T.; Guan, Y.; Wei, T.; Shao, W.; Lin, G. RGD-modified pH-sensitive liposomes for docetaxel tumor targeting. Colloids Surf. B Biointerfaces 2015, 129, 175-182. [CrossRef] [PubMed]

246. Ren, G.; Liu, D.; Guo, W.; Wang, M.; Wu, C.; Guo, M.; Ai, X.; Wang, Y.; He, Z. Docetaxel prodrug liposomes for tumor therapy: Characterization, in vitro and in vivo evaluation. Drug Deliv. 2016, 23, 1272-1281. [CrossRef]

247. Luo, Q.; Yang, B.; Tao, W.; Li, J.; Kou, L.; Lian, H.; Che, X.; He, Z.; Sun, J. ATB $(0,+)$ transporter-mediated targeting delivery to human lung cancer cells via aspartate-modified docetaxel-loading stealth liposomes. Biomater. Sci. 2017, 5, 295-304. [CrossRef]

248. Gu, Z.; Wang, Q.; Shi, Y.; Huang, Y.; Zhang, J.; Zhang, X.; Lin, G. Nanotechnology-mediated immunochemotherapy combined with docetaxel and PD-L1 antibody increase therapeutic effects and decrease systemic toxicity. J. Control Release 2018, 286, 369-380. [CrossRef]

249. Mi, Y.; Liu, Y.; Feng, S.S. Formulation of Docetaxel by folic acid-conjugated d-alpha-tocopheryl polyethylene glycol succinate 2000 (Vitamin E TPGS(2k)) micelles for targeted and synergistic chemotherapy. Biomaterials 2011, 32, 4058-4066. [CrossRef]

250. Shi, C.; Zhang, Z.; Wang, F.; Ji, X.; Zhao, Z.; Luan, Y. Docetaxel-loaded PEO-PPO-PCL/TPGS mixed micelles for overcoming multidrug resistance and enhancing antitumor efficacy. J. Mater. Chem. B 2015, 3, 4259-4271. [CrossRef]

251. Liu, H.; Tu, L.; Zhou, Y.; Dang, Z.; Wang, L.; Du, J.; Feng, J.; Hu, K. Improved Bioavailability and Antitumor Effect of Docetaxel by TPGS Modified Proniosomes: In Vitro and In Vivo Evaluations. Sci. Rep. 2017, 7, 43372. [CrossRef] [PubMed] 
252. Liu, D.; Liu, Z.; Wang, L.; Zhang, C.; Zhang, N. Nanostructured lipid carriers as novel carrier for parenteral delivery of docetaxel. Colloids Surf. B Biointerfaces 2011, 85, 262-269. [CrossRef] [PubMed]

253. Ravar, F.; Saadat, E.; Gholami, M.; Dehghankelishadi, P.; Mahdavi, M.; Azami, S.; Dorkoosh, F.A. Hyaluronic acid-coated liposomes for targeted delivery of paclitaxel, in-vitro characterization and in-vivo evaluation. J. Control Release 2016, $229,10-22$. [CrossRef] [PubMed]

254. Wang, J.; Jia, J.; Liu, J.; He, H.; Zhang, W.; Li, Z. Tumor targeting effects of a novel modified paclitaxel-loaded discoidal mimic high density lipoproteins. Drug Deliv. 2013, 20, 356-363. [CrossRef] [PubMed]

255. Miao, Y.Q.; Chen, M.S.; Zhou, X.; Guo, L.M.; Zhu, J.J.; Wang, R.; Zhang, X.X.; Gan, Y. Chitosan oligosaccharide modified liposomes enhance lung cancer delivery of paclitaxel. Acta Pharm. Sin. 2021. [CrossRef]

256. Zhang, X.G.; Miao, J.; Dai, Y.Q.; Du, Y.Z.; Yuan, H.; Hu, F.Q. Reversal activity of nanostructured lipid carriers loading cytotoxic drug in multi-drug resistant cancer cells. Int. J. Pharm. 2008, 361, 239-244. [CrossRef] [PubMed]

257. Paolino, D.; Celia, C.; Trapasso, E.; Cilurzo, F.; Fresta, M. Paclitaxel-loaded ethosomes(R): Potential treatment of squamous cell carcinoma, a malignant transformation of actinic keratoses. Eur. J. Pharm. Biopharm. 2012, 81, 102-112. [CrossRef] [PubMed]

258. Zhao, B.J.; Ke, X.Y.; Huang, Y.; Chen, X.M.; Zhao, X.; Zhao, B.X.; Lu, W.L.; Lou, J.N.; Zhang, X.; Zhang, Q. The antiangiogenic efficacy of NGR-modified PEG-DSPE micelles containing paclitaxel (NGR-M-PTX) for the treatment of glioma in rats. J. Drug Target. 2011, 19, 382-390. [CrossRef]

259. Song, X.L.; Liu, S.; Jiang, Y.; Gu, L.Y.; Xiao, Y.; Wang, X.; Cheng, L.; Li, X.T. Targeting vincristine plus tetrandrine liposomes modified with DSPE-PEG2000-transferrin in treatment of brain glioma. Eur. J. Pharm. Sci. 2017, 96, 129-140. [CrossRef]

260. Wang, C.; Feng, L.; Yang, X.; Wang, F.; Lu, W. Folic acid-conjugated liposomal vincristine for multidrug resistant cancer therapy. Asian J. Pharm. Sci. 2013, 8, 118-127. [CrossRef]

261. Aboutaleb, E.; Atyabi, F.; Khoshayand, M.R.; Vatanara, A.R.; Ostad, S.N.; Kobarfard, F.; Dinarvand, R. Improved brain delivery of vincristine using dextran sulfate complex solid lipid nanoparticles: Optimization and in vivo evaluation. J. Biomed. Mater. Res. A 2014, 102, 2125-2136. [CrossRef] [PubMed]

262. Gao, X.; Zhang, J.; Xu, Q.; Huang, Z.; Wang, Y.; Shen, Q. Hyaluronic acid-coated cationic nanostructured lipid carriers for oral vincristine sulfate delivery. Drug Dev. Ind. Pharm. 2017, 43, 661-667. [CrossRef]

263. Li, X.T.; He, M.L.; Zhou, Z.Y.; Jiang, Y.; Cheng, L. The antitumor activity of PNA modified vinblastine cationic liposomes on Lewis lung tumor cells: In vitro and in vivo evaluation. Int. J. Pharm. 2015, 487, 223-233. [CrossRef] [PubMed]

264. Amiri, B.; Ahmadvand, H.; Farhadi, A.; Najmafshar, A.; Chiani, M.; Norouzian, D. Delivery of vinblastine-containing niosomes results in potent in vitro/in vivo cytotoxicity on tumor cells. Drug Dev. Ind. Pharm. 2018, 44, 1371-1376. [CrossRef]

265. Bahadori, F.; Topcu, G.; Eroglu, M.S.; Onyuksel, H. A new lipid-based nano formulation of vinorelbine. AAPS Pharm. Sci. Tech. 2014, 15, 1138-1148. [CrossRef] [PubMed]

266. Dadashzadeh, S.; Vali, A.M.; Rezaie, M. The effect of PEG coating on in vitro cytotoxicity and in vivo disposition of topotecan loaded liposomes in rats. Int. J. Pharm. 2008, 353, 251-259. [CrossRef]

267. Yu, Y.; Wang, Z.H.; Zhang, L.; Yao, H.J.; Zhang, Y.; Li, R.J.; Ju, R.J.; Wang, X.X.; Zhou, J.; Li, N.; et al. Mitochondrial targeting topotecan-loaded liposomes for treating drug-resistant breast cancer and inhibiting invasive metastases of melanoma. Biomaterials 2012, 33, 1808-1820. [CrossRef] [PubMed]

268. Souza, L.G.; Silva, E.J.; Martins, A.L.; Mota, M.F.; Braga, R.C.; Lima, E.M.; Valadares, M.C.; Taveira, S.F.; Marreto, R.N. Development of topotecan loaded lipid nanoparticles for chemical stabilization and prolonged release. Eur. J. Pharm. Biopharm. 2011, 79, 189-196. [CrossRef]

269. Hattori, Y.; Shi, L.; Ding, W.; Koga, K.; Kawano, K.; Hakoshima, M.; Maitani, Y. Novel irinotecan-loaded liposome using phytic acid with high therapeutic efficacy for colon tumors. J. Control Release 2009, 136, 30-37. [CrossRef]

270. Din, F.U.; Choi, J.Y.; Kim, D.W.; Mustapha, O.; Kim, D.S.; Thapa, R.K.; Ku, S.K.; Youn, Y.S.; Oh, K.T.; Yong, C.S.; et al. Irinotecanencapsulated double-reverse thermosensitive nanocarrier system for rectal administration. Drug Deliv. 2017, 24, 502-510. [CrossRef]

271. Lin, Y.C.; Kuo, J.Y.; Hsu, C.C.; Tsai, W.C.; Li, W.C.; Yu, M.C.; Wen, H.W. Optimizing manufacture of liposomal berberine with evaluation of its antihepatoma effects in a murine xenograft model. Int. J. Pharm. 2013, 441, 381-388. [CrossRef]

272. Ma, X.; Zhou, J.; Zhang, C.X.; Li, X.Y.; Li, N.; Ju, R.J.; Shi, J.F.; Sun, M.G.; Zhao, W.Y.; Mu, L.M.; et al. Modulation of drug-resistant membrane and apoptosis proteins of breast cancer stem cells by targeting berberine liposomes. Biomaterials 2013, 34, $4452-4465$. [CrossRef] [PubMed]

273. Wang, L.; Li, H.; Wang, S.; Liu, R.; Wu, Z.; Wang, C.; Wang, Y.; Chen, M. Enhancing the antitumor activity of berberine hydrochloride by solid lipid nanoparticle encapsulation. AAPS PharmSciTech 2014, 15, 834-844. [CrossRef] [PubMed]

274. Das, J.; Choi, Y.J.; Han, J.W.; Reza, A.; Kim, J.H. Nanoceria-mediated delivery of doxorubicin enhances the anti-tumour efficiency in ovarian cancer cells via apoptosis. Sci. Rep. 2017, 7, 9513. [CrossRef] [PubMed]

275. Mosquera, J.; Garcia, I.; Liz-Marzan, L.M. Cellular Uptake of Nanoparticles versus Small Molecules: A Matter of Size. ACC Chem. Res. 2018, 51, 2305-2313. [CrossRef]

276. Zeng, X.; Morgenstern, R.; Nystrom, A.M. Nanoparticle-directed sub-cellular localization of doxorubicin and the sensitization breast cancer cells by circumventing GST-mediated drug resistance. Biomaterials 2014, 35, 1227-1239. [CrossRef]

277. Dong, X.; Wang, W.; Qu, H.; Han, D.; Zheng, J.; Sun, G. Targeted delivery of doxorubicin and vincristine to lymph cancer: Evaluation of novel nanostructured lipid carriers in vitro and in vivo. Drug Deliv. 2016, 23, 1374-1378. [CrossRef] 
278. Ganoth, A.; Merimi, K.C.; Peer, D. Overcoming multidrug resistance with nanomedicines. Expert Opin. Drug Deliv. 2015, 12, 223-238. [CrossRef]

279. Meacham, C.E.; Morrison, S.J. Tumour heterogeneity and cancer cell plasticity. Nature 2013, 501, 328-337. [CrossRef]

280. Robey, R.W.; Pluchino, K.M.; Hall, M.D.; Fojo, A.T.; Bates, S.E.; Gottesman, M.M. Revisiting the role of ABC transporters in multidrug-resistant cancer. Nat. Rev. Cancer 2018, 18, 452-464. [CrossRef]

281. Fletcher, J.I.; Haber, M.; Henderson, M.J.; Norris, M.D. ABC transporters in cancer: More than just drug efflux pumps. Nat. Rev. Cancer 2010, 10, 147-156. [CrossRef]

282. Genovese, I.; Ilari, A.; Assaraf, Y.G.; Fazi, F.; Colotti, G. Not only P-glycoprotein: Amplification of the ABCB1-containing chromosome region 7q21 confers multidrug resistance upon cancer cells by coordinated overexpression of an assortment of resistance-related proteins. Drug Resist. Updates 2017, 32, 23-46. [CrossRef] [PubMed]

283. Mathijssen, R.H.; Sparreboom, A.; Verweij, J. Determining the optimal dose in the development of anticancer agents. Nat. Rev. Clin. Oncol. 2014, 11, 272-281. [CrossRef] [PubMed]

284. Drummond, D.C.; Noble, C.O.; Guo, Z.; Hayes, M.E.; Connolly-Ingram, C.; Gabriel, B.S.; Hann, B.; Liu, B.; Park, J.W.; Hong, K.; et al. Development of a highly stable and targetable nanoliposomal formulation of topotecan. J. Control Release 2010, 141, 13-21. [CrossRef] [PubMed]

285. Ahmad, J.; Akhter, S.; Greig, N.H.; Kamal, M.A.; Midoux, P.; Pichon, C. Engineered Nanoparticles Against MDR in Cancer: The State of the Art and its Prospective. Curr. Pharm. Des. 2016, 22, 4360-4373. [CrossRef]

286. Auria-Soro, C.; Nesma, T.; Juanes-Velasco, P.; Landeira-Vinuela, A.; Fidalgo-Gomez, H.; Acebes-Fernandez, V.; Gongora, R.; Almendral Parra, M.J.; Manzano-Roman, R.; Fuentes, M. Interactions of Nanoparticles and Biosystems: Microenvironment of Nanoparticles and Biomolecules in Nanomedicine. Nanomaterials 2019, 9, 1365. [CrossRef] [PubMed]

287. Ernsting, M.J.; Murakami, M.; Roy, A.; Li, S.D. Factors controlling the pharmacokinetics, biodistribution and intratumoral penetration of nanoparticles. J. Control Release 2013, 172, 782-794. [CrossRef]

288. Saptarshi, S.R.; Duschl, A.; Lopata, A.L. Interaction of nanoparticles with proteins: Relation to bio-reactivity of the nanoparticle. J. Nanobiotechnol. 2013, 11, 26. [CrossRef]

289. Gustafson, H.H.; Holt-Casper, D.; Grainger, D.W.; Ghandehari, H. Nanoparticle Uptake: The Phagocyte Problem. NANO Today 2015, 10, 487-510. [CrossRef]

290. Tavares, A.J.; Poon, W.; Zhang, Y.N.; Dai, Q.; Besla, R.; Ding, D.; Ouyang, B.; Li, A.; Chen, J.; Zheng, G.; et al. Effect of removing Kupffer cells on nanoparticle tumor delivery. Proc. Natl. Acad. Sci. USA 2017, 114, E10871-E10880. [CrossRef]

291. Tsoi, K.M.; MacParland, S.A.; Ma, X.Z.; Spetzler, V.N.; Echeverri, J.; Ouyang, B.; Fadel, S.M.; Sykes, E.A.; Goldaracena, N.; Kaths, J.M.; et al. Mechanism of hard-nanomaterial clearance by the liver. Nat. Mater. 2016, 15, 1212-1221. [CrossRef]

292. He, H.; Liu, L.; Morin, E.E.; Liu, M.; Schwendeman, A. Survey of Clinical Translation of Cancer Nanomedicines-Lessons Learned from Successes and Failures. ACC Chem. Res. 2019, 52, 2445-2461. [CrossRef] [PubMed]

293. Kamoun, W.S.; Dugast, A.-S.; Suchy, J.J.; Grabow, S.; Fulton, R.B.; Sampson, J.F.; Luus, L.; Santiago, M.; Koshkaryev, A.; Sun, G.; et al. Synergy between EphA2-ILs-DTXp, a Novel EphA2-Targeted Nanoliposomal Taxane, and PD-1 Inhibitors in Preclinical Tumor Models. Mol. Cancer Ther. 2020, 19, 270. [CrossRef]

294. Hafner, A.; Lovric, J.; Lakos, G.P.; Pepic, I. Nanotherapeutics in the EU: An overview on current state and future directions. Int. J. Nanomed. 2014, 9, 1005-1023. [CrossRef]

295. Wang-Gillam, A.; Hubner, R.A.; Siveke, J.T.; Von Hoff, D.D.; Belanger, B.; de Jong, F.A.; Mirakhur, B.; Chen, L.T. NAPOLI-1 phase 3 study of liposomal irinotecan in metastatic pancreatic cancer: Final overall survival analysis and characteristics of long-term survivors. Eur. J. Cancer 2019, 108, 78-87. [CrossRef]

296. Zhang, Q.; Huang, X.E.; Gao, L.L. A clinical study on the premedication of paclitaxel liposome in the treatment of solid tumors. Biomed. Pharm. 2009, 63, 603-607. [CrossRef]

297. Xu, X.; Wang, L.; Xu, H.Q.; Huang, X.E.; Qian, Y.D.; Xiang, J. Clinical comparison between paclitaxel liposome (Lipusu(R)) and paclitaxel for treatment of patients with metastatic gastric cancer. Asian Pac. J. Cancer Prev. 2013, 14, 2591-2594. [CrossRef]

298. Hsu, J.-F.; Chu, S.-M.; Liao, C.-C.; Wang, C.-J.; Wang, Y.-S.; Lai, M.-Y.; Wang, H.-C.; Huang, H.-R.; Tsai, M.-H. Nanotechnology and Nanocarrier-Based Drug Delivery as the Potential Therapeutic Strategy for Glioblastoma Multiforme: An Update. Cancers 2021, 13, 195. [CrossRef]

299. Wang, Z.-Y.; Zhang, H.; Yang, Y.; Xie, X.-Y.; Yang, Y.-F.; Li, Z.; Li, Y.; Gong, W.; Yu, F.-L.; Yang, Z.; et al. Preparation, characterization, and efficacy of thermosensitive liposomes containing paclitaxel. Drug Deliv. 2016, 23, 1222-1231. [CrossRef]

300. Peng, J.Q.; Fumoto, S.; Suga, T.; Miyamoto, H.; Kuroda, N.; Kawakami, S.; Nishida, K. Targeted co-delivery of protein and drug to a tumor in vivo by sophisticated RGD-modified lipid-calcium carbonate nanoparticles. J. Control Release 2019, $302,42-53$. [CrossRef]

301. Du, Y.; Wang, Z.; Wang, T.; He, W.; Zhou, W.; Li, M.; Yao, C.; Li, X. Improved Antitumor Activity of Novel Redox-Responsive Paclitaxel-Encapsulated Liposomes Based on Disulfide Phosphatidylcholine. Mol. Pharm. 2020, 17, 262-273. [CrossRef] [PubMed]

302. Ferreira, G.S.; Veening-Griffioen, D.H.; Boon, W.P.C.; Moors, E.H.M.; Gispen-de Wied, C.C.; Schellekens, H.; van Meer, P.J.K. A standardised framework to identify optimal animal models for efficacy assessment in drug development. PLoS ONE 2019, 14, e0218014. [CrossRef] [PubMed]

303. Van Norman, G.A. Limitations of Animal Studies for Predicting Toxicity in Clinical Trials: Is it Time to Rethink Our Current Approach? JACC Basic Transl. Sci. 2019, 4, 845-854. [CrossRef] [PubMed] 
304. FitzGerald, L.I.; Johnston, A.P.R. It's what's on the inside that counts: Techniques for investigating the uptake and recycling of nanoparticles and proteins in cells. J. Colloid. Interface Sci. 2021, 587, 64-78. [CrossRef] [PubMed]

305. Rennick, J.J.; Johnston, A.P.R.; Parton, R.G. Key principles and methods for studying the endocytosis of biological and nanoparticle therapeutics. Nat. Nanotechnol. 2021, 16, 266-276. [CrossRef] [PubMed]

306. Ouyang, B.; Poon, W.; Zhang, Y.N.; Lin, Z.P.; Kingston, B.R.; Tavares, A.J.; Zhang, Y.; Chen, J.; Valic, M.S.; Syed, A.M.; et al. The dose threshold for nanoparticle tumour delivery. Nat. Mater. 2020, 19, 1362-1371. [CrossRef] 